\title{
The Ecology of the Red Rainbowfish (Glossolepis incisus) and the Impact of Human Activities on Its Habitats in Lake Sentani, Papua
}

\author{
Dissertation \\ for the award of the degree \\ "Doctor rerum naturalium" (Dr. rer. nat.) \\ Division of Mahematics and Natural Sciences \\ of the Georg-August Universität Göttingen \\ within the doctoral program biology \\ of the Georg-August University School of Science (GAUSS)
}

submitted by

Henderite Loisa Ohee

from Papua, Indonesia

Göttingen, 2013 
Thesis Committee

Department of Conservation Biology, Center for Nature Conservation

Prof. Dr. Rainer Willmann

Department of Morphology, Systematic, Evolutions Biology

\section{Members of the Examination Board}

Department of Conservation Biology, Center for Nature Conservation

Second Reviewer: Prof. Dr. Rainer Willmann

Department of Morphology, Systematic, Evolutions Biology

Further members of the Examination Board:

Prof. Dr. Erwin Bergmeier

Department of Vegetation and Phytodiversity Analysis

PD Dr. Thomas Hörnschemeyer

Department of Morphology, Systematic, Evolutions Biology

Prof. Dr. Eckhard W. Heymann

Behavioral Ecology and Sociobiology Unit, German Primate Center

Prof. Dr. Daniel J. Jackson

Courant Research Center Geobiology

Place and Date of the oral examination: Computer Room, Department of Conservation Biology, Center for Nature Conservation, Bürgerstraße 50, 37073 Göttingen; September 25, 2013 at 15:00pm 
All of us do not have equal talent, but all of us should have equal opportunity to develop our talents.

John F. Kennedy, 1963 


\section{Acknowledgments}

I would never have been able to finish my study and dissertation without the guidance of my committee members, help from friends, and support from my family.

I extend a special thank you to my supervisor, Prof. M. Mühlenberg, for his help, support, and guidance throughout the entirety of my study.

I would also like to thank my mother for her unwavering support and great patience at all times until the end of her life. My sister, brothers, and relatives have given me their unequivocal support throughout, as always, for which the mere expression of thanks likewise does not suffice.

I am most grateful to Yance de Fretes, Ph.D, for his patience, encouragement, and constructive criticism. His knowledge during the writing of this dissertation was invaluable.

My study would not have been possible without generous financial support from the Directorate General of Higher Education, Ministry of Education and Culture, Indonesia. I also thank the Education and Culture Department of Papua Province for their financial support during our field research in Papua.

I would also like to show my gratitude to the staff of the Center for Nature Conservation, Georg-August University of Göttingen, and my colleagues in the Department of Biology, Mathematics and Sciences Faculty, Cenderawasih University, Papua, for their help and moral support.

Finally, I want to thank the friends of PSM of GKI Siloam in Waena, Jayapura, Papua; my Indonesian friends in Göttingen, Germany, for their friendship and prayers; and Carsten Schröder for his attention and support during my study. I would also like to thank Sacha Viquerat and William Marthy for their help and advice in using R, and Alex for guiding me through many revisions. I will forever be indebted to Dr.rer.nat. Margaretha Pangau for her support, which included many of the little things of life in a new, unfamiliar country. 


\section{Summary}

Located in the western half of New Guinea, Papua is facing rapid and poorlyplanned social and economic development, increasing habitat degradation and threatening its high level of species richness and endemicity. Freshwater ecosystems, more than any other biotope in Papua, face the worst consequences from human development through sedimentation, habitat alteration, pollution, and the introduction of exotic species. However, little research has been conducted on the impact of human activities on aquatic species, and specifically fish in lentic and lotic ecosystems, in Papua.

Lake Sentani is located in northern Papua, near Jayapura, the capital of Papua Province. It is the largest lowland lake in Papua, and plays a critical role in the survival of the humans and organisms living in and around it. Human activities are negatively affecting its local flora and fauna, especially those with very narrow distributions, such as the rainbowfishes, Chilatherina sentaniensis and Glossolepis incisus, and the Sentani Goby (Glossogobius sp.). The lake is located close to an urban center and heavy development occurs in the north, east, and northeast, while other threats include non-point pollution of human activities, habitat alteration along the shoreline, and introduced species. Despite these concerns, and its proximity to the local government, the lake has received no attention in terms conserving its ecosystem. Moreover, although there is some research on the mollusks, phytoplankton, limnological aspects, and water quality of the lake, none exists specifically on the correlation between human activities and the lake's inhabitants. Therefore, the aim of this study was to document the ecology of the Red Rainbowfish (Glossolepis incisus), one of the threatened endemic fishes in Lake Sentani, and the impact of human activities on its habitats. Specifically, this study was designed to focus on the impact of human activities on the abundance of the Red Rainbowfish, its body length, and sex ratio, and the abundance of introduced fishes and correlation between their abundance and Red Rainbowfish abundance. Assessing the impact of human 
activities was done by measuring eight water physicochemical parameters that were reported to have the most potential influence on the abundance of the Red Rainbowfish, in nine locations from three zones. The zones were predetermined based on visual assessments of the level of human activities, where higher numbers of people were assumed to have higher impacts on the environment. Zone I's locations had heavy human activity, Zone II's locations had medium human activity, and Zone III's locations had the lowest human activity and was considered a "control area". These zones' locations were later regrouped following analyses of the water physicochemical parameters.

Fish and water samples were collected along the shoreline, at depths of up to two meters. Fish were sampled in the morning at each sampling site of a single location, and replicated three times on alternate days, yielding 27 data sets for each zone, or 81 data sets for all three zones within a year, and a total 243 data sets in three years. Collected rainbowfish were differentiated by sex, counted, measured, and released. Water parameters were measured in the same sites in which fish sampling was conducted, three times a day-morning (06.00-09.00 am), midday (11.00 am-13.00 pm), and afternoon (16.00-18.00 pm)-and repeated three times in each sampling site on three alternate days. Thus, a total of 81 water parameter data sets were collected. Water parameters, including nitrate, nitrite, phosphate, biological oxygen demand, and chemical oxygen demand were analyzed in a laboratory, while water temperature, $\mathrm{pH}$, and dissolved oxygen were directly measured in the field. Then, the ecology of the rainbowfish was descriptively analyzed to assess the preferred habitat of the fish, including substrate type, water depth, turbidity, and vegetation. The R statistical analysis program was used to analyze the water physicochemical parameters in order to determine the level of pollution in the water, abundance of Red Rainbowfish in each sampling group, and correlation between water physicochemical parameters and Red Rainbowfish abundance and body size. After the level of water pollution was determined, fish samples were arranged into three groups based on the level of pollution in their location. The Analysis 
Toolpak in Microsoft Excel 2007, and SPSS version 17.0 were used to calculate Red Rainbowfish body length for each group, as well as the difference between groups, correlation between Red Rainbowfish abundance and introduced fish abundance, and Red Rainbowfish abundance and nitrate concentration.

Based on the aforementioned water physicochemical parameters, the sampling sites were distinguished into three groups: Groups 1 and 2 indicated heavy pollution (human impact) and Group 3 indicated low pollution (human impact) with fairly good water quality. There were significant differences in certain physicochemical parameters between groups, specifically in nitrate, nitrite, phosphate, BOD, and COD. Group 1 had the highest concentrations of nitrate and nitrite, while Group 2 had the highest concentrations of phosphate, BOD and COD. Group 3 had the best water quality of the three groups, with low to medium concentrations of each parameter. Phosphate levels in all three groups exceeded the Indonesian government's phosphate limit in drinking water and fisheries, with BOD and COD. Nitrate and nitrite were both still within the limit. No area with zero human impact was found, even in sites with a population as low as two people. These results indicate that Lake Sentani already suffers from a high level of organic matter, which enters the lake as the result of human activities around it.

Red Rainbowfish abundance was not different between groups, except when fish were counted based on their sex. Male abundance remained similar across groups, whereas female abundance was similar in Groups 1 and 2, but much lower in Group 3. Nitrate was the only water parameter significantly correlating negatively with Red Rainbowfish abundance, suggesting that increased nitrate levels had an effect in decreasing fish abundance in Lake Sentani, although the impact was still low.

Red Rainbowfish body length was significantly different between groups, with Group 3 having the longest mean body length. Phosphate was the only parameter found to contribute to Red Rainbowfish body length, albeit nonsignificantly. 
Introduced fish abundance correlated weakly with Red Rainbowfish abundance. While Group 2 showed a weak negative correlation, Group 1 and Group 3 revealed a weak positive correlation, suggesting that, whether positive or negative, introduced fish species had a very low influence on the abundance of the Red Rainbowfish.

Male Red Rainbowfish were more abundant than females in the shallow waters along the shoreline, the latter being found more commonly in deeper waters. This ratio was similar in Groups 1 and 2, whereas Group 3, whose habitats were the least polluted, had a higher ratio of males. The disparity in sex ratio was possibly caused by their different habitat preferences, as well as light and temperature preferences.

The overall habitat preference of the Red Rainbowfish was clear, shallow water, sand, gravel, and cobble substrate, and shoaling amidst Hydrilla verticillata, Valisneria americana, Eichhornia crassipes, Metroxylon sagu, and grasses. The availability of food also attracted fish to certain areas, such as under traditional stilt houses, roots of some plants, litter, and wood debris. The pollen of terrestrial plants, as well as terrestrial insects, also served as a food source for the fish, along with the larvae of aquatic insects and algae. Roots of plants were also important for refuge, and as nursery and playing grounds. Moreover, the fish avoided high light intensities by moving to shaded areas or deeper water. These factors influenced the Red Rainbowfish's distribution and habitat selection, and consequently, its abundance.

Human activities in and around Lake Sentani have impacted the quality of its habitats and water. Although water quality did not have a significant influence on the Red Rainbowfish, owing to its ability to adapt to changes in water quality, changes to its habitat will have a significant impact on its ability to survive in Lake Sentani. The outcome of the present rate of pollution of its water will be further and more serious deterioration of its ecosystem, force its inhabitants to compete for increasingly fewer resources, and ultimately result in the extinction of its endemic species, of which the Red Rainbowfish is just one example. Therefore, 
Lake Sentani should be made a priority in Papuan conservation and management efforts, especially for native and endemic species.

The results of this study provide baseline data for Red Rainbowfish conservation in Lake Sentani, and will allow policy-makers to pursue the protection of its habitats, create a strategy to control pollutants, and encourage community-based environmental management. Further research is needed on the correlation between the Red Rainbowfish and its preferences, and its susceptibility to certain types and concentrations of pollutants. Different strategies of pollution control should also be investigated. Other parts of Lake Sentani that were beyond the scope of this research should also be surveyed, along with a lake-wide program examining the exact condition of Lake Sentani's ecosystem, whether it be the quality of its water or the response of its flora and fauna to ongoing anthropogenic disturbance, after which a more comprehensive rehabilitation program may follow. 


\section{Zusammenfassung}

Das in der westlichen Hälfte der Insel Neuguinea liegende Papua unterliegt einer raschen, unzureichend geplanten sozialen und ökonomischen Entwicklung. Zunehmende Umweltzerstörung (Habitatdegradierung) bedroht den hohen Artenreichtum und die einheimische Biodiversität. Süßwasserökosysteme sind sehr stark bedroht durch Umweltverschmutzung, Habitatsveränderung und das Einschleppen von fremden Arten. Bisher wurde dieser menschliche Einfluss an den Süßwasserarten unzureichend erforscht, speziell an den Fischen in stehenden und fliessenden Gewässern in Papua.

Der Sentani See liegt in Nordpapua, in der Nähe von Jayapura, der Hauptstadt der Provinz Papua. Es repräsentiert das größte Süßwasserökosystem in Papua und spielt somit eine wichtige Rolle für das Überleben der Menschen und anderer Lebewesen in dieser Gegend. Menschliche Aktivitäten beeinflussen die lokale Flora und Fauna, insbesondere solche mit engem Verbreitungsgebieten wie z.B. Regenbogenfische Chilatherinasentaniensis und Glossolepisincisus, und der Sentani Goby. (Glossogobius sp.) Der See liegt nahe an urbanen Zentren, sodass in allen Himmelsrichtungen Umweltverschmutzungen aller Art stattfinden., dies betrifft insbesondere Veränderungen im Uferbereich und das Einschleppen fremder Arten. Trotz dieser Bedenken und der Bedeutung für die lokale Regierung findet das Thema kaum Beachtung im Hinblick auf Erhalt des Ökosystems. Trotz einiger Forschung in Richtung Mollusken, Phytoplankton und Limnologie, und Wasserqualität des Sees gibt es keine spezifischen Untersuchungen über die Korrelation zwischen menschlichen Aktivitäten und der Artenveränderung im See. Deshalb ist das Ziel dieser Arbeit die Ökologie des roten Regenbogenfisches als einem der meistbedrohten endemischen Fischarten im Sentanisee sowie den menschlichen Einfluss auf sein Habitat zu dokumentieren. Im Speziellen beschreibt diese Arbeit den Einfluss auf die Häufigkeit, Größe, Geschlechterverteilung und Populationsveränderung nach Einführung fremder Arten. Um den menschlichen 
Faktor zu messen, wurden acht physiochemische Parameter untersucht, von denen der größte Einfluss auf die Häufigkeit des Vorkommens beschrieben wird in neun verschiedenen Gegenden dreier verschiedener Zonen. Die Gegenden wurden nach Kriterien unterschiedlicher menschlicher Aktivität ausgesucht unter der Hypothese, dass eine höhere menschlicher Population einen entsprechenden Einfluss auf die Fischpopulation hat. Zone I beschreibt hohen menschlichen Einfluss, Zone II mittelmäßige menschliche Aktivität, Zone III hat die niedrigste menschliche Aktivität und wurde als „Kontrollgegend“ genutzt. Diese Gegenden wurden später neu eingeteilt gemäß der physiochemischen Parameter des Wassers.

Fisch und Wasserproben wurden entlang des Ufers gesammelt, in bis zu zwei Meter Tiefe. Fisch wurde morgens in jeder Zone gefangen. Dies wurde dreimal an anderen Tagen wiederholt, sodass 27 verschieden Daten für jede Zone zusammenkamen, insgesamt 81 Daten für drei Zonen innerhalb eines Jahres, und somit 243 Daten in drei Jahren. Die gesammelten Regenbogenfische wurden nach Geschlecht gezählt, gemessen und wieder freigelassen. Wasserproben wurden nach dem gleichen Muster entnommen, dreimal täglich; morgens (6.00 9.00am), mittags (11.00 bis $13.00 \mathrm{pm})$ und nachmittags $(16.00-18.00 \mathrm{pm})$ und dreimal in jeder Zone an drei weiteren Tagen gesammelt. So wurden ebenfalls 81 Wasserproben gewonnen. Die Wasserparameter, Nitrate, Nitrite, Phosphate, der biologische Sauerstoffbedarf und der chemische Sauerstoffbedarf wurden in einem Labor analysiert, während Wassertemperatur, PH Wert und gelöster Sauerstoff direkt vor Ort gemessen wurden. Dann wurde das Umfeld des Regenbogenfisches beschreibend analysiert, um die Habitatpräferenzen einschliesslich Substrat, Typ, Wassertiefe, Wasserbewegung und Vegetation kennezulernen. Um die physiochemischen Parameter des Wassers zu analysieren, wurde das RStatistikanalyse Programm benutzt., um somit Verbreitung und Größe des Regenbogenfisches in jeder Probe, und somit eine Korrelation zwischen den Wasserparametern und der Größe und Verteilung des 
Regenbogenfisches zu entdecken. Nachdem der Grad der Wasserverschmutzung bestimmt worden war, wurden die Fischproben in drei Gruppen eingeteilt, je nach Verschmutzungsgrad der Gebiete. Das Analysetool in Excel 2007 und die Version von SPSS 17.0 wurden genutzt, um die Fischgröße jeder Gruppe, sowie den Unterscheid der Gruppen zueinander, das Verhältnis der Anzahl der Fische zur Zahl der eingeführten fremden Fische, sowie die Korrelation der Zahl der Regenbogenfische zur Nitratkonzentration zu bestimmen.

Basierend auf den bereits erwähnten Wasserparametern wurden die Untersuchungsgebiete in drei Gruppen geteilt. 1 und 2 mit hohem menschlichen Einfluss, 3 mit geringem menschlichem Impact. Es gab signifikante Unterschiede bei bestimmten Wasserparametern innerhalb der Gruppen, insbesondere bei Nitraten und Nitriten, Phosphate, biologischem Sauerstoffbedarf und chemischen Sauerstoffbedarf. Die erste Gruppe hatte die höchste Konzentration an Nitraten und Nitriten, Gruppe II hatte die höchste Konzentration an Phosphaten, biologischem, sowie chemischen Sauerstoffbedarf . Gruppe drei hatte die beste Wasserqualität und niedere bis mittlere Konzentration der obengenannten Parameter. Die Phosphatlevel übersteigen den in Indonesien staatlich zugelassenen Grenzwert von Phosphat in Trinkwasser und Fischereiwasser. Nitrat und Nitritbelastung liegen unter den zulässigen Grenzwerten. Es wurde kein Bereich ohne nachweisbaren menschlichen Einfluss gefunden, nicht mal bei so geringer Bev.dichte wie 2Menschen / km2;

Diese Ergebnisse zeigen die deutliche Verschmutzung des Sentani Sees durch die Menschen.

Die Anzahl des roten Regenbogenfisches war in allen Gruppen gleich, ausser es wurde nach Geschlecht getrennt gezählt. Die männlichen Fische war in allen Gruppen ähnlich, während die Anzahl weinblichen Fische in der Gruppe drei niedriger war. Nitrat war der einzige Parameter, dem ein direkter inverser Zusammenhang mit der Anzahl der Regenbogenfische nachgewiesen werden konnte. 
Die Körperlänge der Fische war signifikant unterschiedlich in den einzelnen Gruppen. Gruppe drei hatte das durchschnittlich größte Körpermass. Phosphat war der einzige Parameter mit Einfluss auf die Körperlänge, obwohl nicht signifikant. Die Anzahl der Fremdfische korrelierte schwach mit der Anzahl der Regenbogenfische. Gruppe zwei hatte eine leicht negative Korrelation, Gruppe eins und drei waren leicht positiv korreliert. Das bedeutet, dass die Anzahl der Fremdfische keinen Einfluss auf die Zahl der Regenbogenfische hat.

Die Zahl der männliche Regenbogenfische war in der Flachwasserzone am Ufer höher, während die weiblichen mehr in den tiefen Wassern gefunden wurden. Diese Korrelation war ähnlich in Gruppe eins und zwei, während in der dritten weniger verschmutzten Gruppe eine höhere Anzahl männlicher Fische war. Die unterschiedliche Geschlechterverteilung war abhängig von Habitat, Licht und Temperaturpräferenzen.

Grundsätzlich bevorzugen rote Regenbogenfische klares, flaches Wasser mit Sand, Kiesel und Steinsubstrat und halten sich gerne auf zwischen Hydrilla verticillata, Valisneria americana, Eichhornia crassipes, Metroxylon sagu und Gräsern. Das Angebot von Futter war ebenfalls attraktiv für die Fische, insbesondere unter traditionellen Pfahlhäusern, den Wurzeln einiger Pflanzen, Schmutz, Abfall und Holzresten. Pollen und Insekten waren ebenfalls eine bedeutende Nahrungsquelle für die Fische, sowie auch die Larven von Wasserinsekten und Algen. Pflanzwurzeln waren ebenfalls als Rückzugs- und Aufzuchtsgebiet sowie als Spielplatz attraktiv für die Fische. Die Fische vermieden Bereiche mit hohen Lichtintensitäten und zogen schattige Gebiete in tiefem Wasser vor. Diese Faktoren beeinflussten die Verbreitung der Regenbogenfische in den Habitaten und konsequenterweise auch ihre Anzahl.

Menschliche Aktivitäten haben Einfluss auf die Qualität des Habitats und des Wassers in und um den Sentanisee. Obwohl die Wasserqualität keinen signifikanten Einfluss auf die Verbreitung der Regenbogenfische hat, dank seiner Fähigkeit, sich auch an schlechtere Konditionen anzupassen, wird eine zunehmende Verschmutzung doch als Bedrohung gewertet. Zunehmende 
Verschmutzung des Wassers wird sich in einer Verschlechterung des Ökosystems zeigen und wird dazu führen, dass die Arten um geringere Ressourcen konkurrieren müssen. Das wird ultimativ zum Aussterben von endemischen Arten führen, von denen der rote Regenbogenfisch nur ein Vertreter ist. Deshalb sollte der Sentani See prioriär als Naturschutzgebiet in Papua behandelt werden, um einheimische und endemische Arten zu schützen.

Die Ergebnisse dieser Studie liefern Grundlagen Daten für den Schutz des roten Regenbogenfisches im Sentani See. Somit erhalten Politiker Strategien zum Erhalt des Habitats, Möglichkeiten Verschmutzung einzudämmen, und Kommunen zum Naturschutz zu motivieren. Weitere Studien werden benötigt, um das Verhältnis des roten Regenbogenfisches und seine Vorlieben, sowie seine Anfälligkeiten bestimmten Noxen gegenüber zu erforschen. Verschiedene Möglichkeiten der Kontrolle der Verschmutzung sollten ebenfalls erforscht werden. Andere Regionen des Sees, die in dieser Studie nicht erforscht werden konnten, sollten überwacht werden. Unabhängig von den bearbeiteten Untersuchungen am Ökosystem des "Sentani Sees" als Teil eines ganzheitlichen "Sentani See Programms" sollten weitere Studien zur Wasserqualität und insbesondere zum Einfluß anthropogener Umweltverschmutzung auf Flora und Fauna angestellt werden. Eine Überwachung des gesamten Sees zur Bestimmung der Ökologie wäre sinnvoll, damit ein Gesamtprogramm zur ökologischen Rehabilitation folgen kann. 


\section{Table of Contents}

Acknowledgments $\quad$ iv

Summary $v$

Zusammenfassung $x$

Table of Contents $\quad x v$

List of Tables xvii

List of Figures xviii

1 Introduction 1

1.1 Introduction to Papua's Biodiversity 1

1.2 Research Objectives $\quad 5$

2 Ecology of the Red Rainbowfish and the Impact of Human 6

Activities on Its Habitats

2.1 The New Guinea Freshwater Fishes 6

2.1.1 Biodiversity of Freshwater Fishes in New Guinea Island 6

2.1.2 Status and Conservation Measures of Freshwater Fishes 6

2.1.3 New Discoveries 9

2.2 The Ecology of the Red Rainbowfish 9

$\begin{array}{ll}2.2 .1 & \text { Distribution } \\ 2.2 .2 & 10\end{array}$

2.2.2 Habitat 13

$\begin{array}{lll}2.2 .3 \text { Diet } & 16\end{array}$

$\begin{array}{lll}2.2 .4 & \text { Reproduction } & 17\end{array}$

$\begin{array}{lll}2.2 .5 & \text { Ecological Roles } & 17\end{array}$

2.3 Human Impact around Lake Sentani and Its Threats to the Rainbowfish $\quad 17$

2.4 The Red Rainbowfish: Status and Conservation Efforts 22

3 Research Methods $\quad 23$

$\begin{array}{ll}3.1 \text { Study Area } & 23\end{array}$

$\begin{array}{ll}3.2 \text { Sampling Protocols } & 24\end{array}$

3.2.1 Sampling Sites $\quad 25$

3.2.1.1 Zone I 25

3.2.1.2 Zone II 25

3.2.1.3 Zone III 25

$\begin{array}{ll}3.3 \text { Study Period } & 28\end{array}$

3.4 Data Collection 28

3.4.1 Red Rainbowfish Abundance 28

3.4.2 Physicochemical Parameters 29

3.4.3 Red Rainbowfish Habitat Characteristics $\quad 30$

$\begin{array}{ll}3.5 \text { Data Analyses } & 31\end{array}$

3.5.1 Impact of Human Activities on the Red Rainbowfish 31

3.5.2 Red Rainbowfish Abundance 32 
3.5.3 Red Rainbowfish Abundance and Its Correlation with Physicochemical Parameters and Introduced Fish

3.5.4 Body Length of the Red Rainbowfish and Its Correlation with Water Physicochemical Parameters

3.5.5 Sex Ratio of the Red Rainbowfish Between Groups 33

3.5.6 Red Rainbowfish Habitat Characteristics 33

4 Results

4.1 Impact of Human Activities on Rainbowfish Habitats in

Lake Sentani

4.2 Differences between groups in Water Physichochemical Parameters

4.3 Impact of Pollutants on the Red Rainbowfish

4.3.1 Impact of Pollutants on Red Rainbowfish Abundance 38

4.3.2 Impact of Pollutants on Red Rainbowfish Body Length 39

4.4 Impact of Introduced Species on Red Rainbowfish Abundance 41

4.5 Sex ratio of Red Rainbowfish 43

4.6 Substrate types $\quad 44$

4.7 Vegetation $\quad 45$

4.8 Water depth $\quad 46$

5 Discussion $\quad 48$

5.1 Sampling Methods $\quad 48$

5.1.1 Zonation of Sampling Sites 49

5.1.2 Water Sampling $\quad 50$

5.1.3 Fish Sampling $\quad 50$

5.2 Impacts of Human Activities on Red Rainbowfish Habitats in Lake Sentani 52

5.3 Water quality changes in Lake Sentani $\quad 54$

5.4 Red Rainbowfish Abundance in Lake Sentani and the Impact of Pollutants on Abundance

5.5 Red Rainbowfish Body Length and the Impact of Pollutants on Body Length $\quad 61$

5.6 Correlation between Red Rainbowfish and Introduced Fish 62

5.7 Sex Ratio of the Red Rainbowfish 64

5.8 Red Rainbowfish Habitat Preferences $\quad 65$

5.9 Conservation of the Red Rainbowfish 70

6 Conclusion $\quad 73$

$\begin{array}{ll}\text { References } & 76\end{array}$

Appendices $\quad 89$

$\begin{array}{lr}\text { Curriculum Vitae } & 118\end{array}$ 


\section{List of Tables}

Table 2.1. Rainbowfish genera and number of species per genus 14

Table 2.2. Fishes in Lake Sentani 20

Table 3.1. Fish and water sampling periods $\quad 29$

Table 4.1. Means of water physicochemical parameters in different groups 35

Table 4.2. Means of fish captured in each sampling site within group per sampling 38

Table 4.3. Female Red Rainbowfish abundance 38

Table 4.4. Correlation between Red Rainbowfish abundance and the water physicochemical parameters, Nitrate 39

Table 4.5. Body Length (mm SL) of the Red Rainbowfish 40

Table 4.6. Results of Tukey's HSD test on Red Rainbowfish body length $\quad 40$

Table 4.7. Correlation between phosphate and Red Rainbowfish body length 40

Table 4.8. Sex ratio of the Red Rainbowfish 43 


\section{List of Figures}

Figure 2.1. The distribution of number of rainbowfishes species per genus

Figure 2.2. Numbers of rainbowfish species in New Guinea and Australia 12

Figure 2.3. Distribution of 47 rainbowfish species in Papua, which includes 40 species endemic to Papua, five New Guinean species, and two New Guinean and Australian species

Figure 2.4. Male and female Glossolepis incisus

Figure 3.1. Lake Sentani, one of a number of freshwater ecosystems found in Northern New Guinea Island 24

Figure 3.2. Maps of the research locations 27

Figure 4.1. Grouping of sampling sites based on water physicochemical parameters

Figure 4.2. Mean water temperature of the three groups 36

Figure 4.3. Mean water $\mathrm{pH}$ of the three groups 36

Figure 4.4. Mean Dissolved Oxygen (DO) of the three groups 36

Figure 4.5. Mean $\mathrm{NO}_{3}{ }^{-}$of the three groups 36

Figure 4.6. Mean $\mathrm{NO}_{2}{ }^{-}$of the three groups 37

Figure 4.7. Mean $\mathrm{PO}_{4}{ }^{3-}$ of the three groups $\quad 37$

Figure 4.8. Mean BOD of the three groups 38

Figure 4.9. Mean COD of the three groups 38

Figure 4.10. Pearson's correlation coefficient of nitrate to Red Rainbowfish abundance in Lake Sentani 39

Figure 4.11. Number of the seven of introduced fishes collected in the same habitat of Red Rainbowfish. Pooled from all three years of sampling

Figure 4.12. Pearson's correlation coefficient of Red Rainbowfish abundance to introduced fish abundance in Group 1

Figure 4.13. Pearson's correlation coefficient of Red Rainbowfish abundance to introduced fish abundance in Group 2

Figure 4.14. Pearson's correlation coefficient of Red Rainbowfish abundance to introduced fish abundance in Group 3

Figure 4.15. Red Rainbowfish abundance in different substrate types. Pooled from all three years of sampling

Figure 4.16. Red Rainbowfish abundance in different substrate types, from $2009-2011$

Figure 4.17. Red Rainbowfish abundance and its relation to the water and terrestrial plants in each location. Pooled from all three years of sampling

Figure 5.1. Red Rainbowfish body length classes and its abundance in each location 


\section{Introduction}

\subsection{Introduction to Papua's Biodiversity}

Papua is known to harbor extraordinary biological diversity, with many native and endemic species. It has a large track of pristine and diverse ecosystems, including vast freshwater swamps, lowland rainforests, and alpine ecosystems. Biological surveys revealed that the Raja Ampat Islands and Cenderawasih Bay area in Papua formed the center of the Coral Triangle-the most diverse coral reef on Earth. Recent surveys across the province of Papua also discovered many new species (Beehler et al., forthcoming).

Papua supports a rich and diverse fauna that includes at least 3,764 vertebrates, constituting $81 \%$ of the vertebrates found on the island of New Guinea (4,665 species) and probably more than 200,000 invertebrates. Marine fishes make up $62 \%$ of the Papuan fauna, while freshwater and brackish fishes comprise nearly $8 \%$. Birds make up nearly $15 \%$ of Papuan vertebrates, followed by amphibians and reptiles with a combined $10 \%$. The smallest number of Papuan fauna known so far belongs to the mammals, which comprise $5 \%$ of the total. If we focus on land and freshwater vertebrates (i.e., exclude marine and brackish water fishes as well as other exclusively marine vertebrates such as sea turtles and sea snakes), there are 1,240 species known from Papua, but only 250 of these (20\%) are endemic. In comparison, there are a total of 1,674 land and freshwater vertebrates found throughout the entire island of New Guinea, 1,130 (69\%) of which are endemic (Allison 2007). Besides being rich in terms of number of species and diverse natural ecosystems, Papua also has a high level of species endemism compared with the rest of Indonesia. It was estimated that Papua contributes $30-50 \%$ of Indonesia's biodiversity (Conservation International 1999).

New Guinea Island as a whole has a complex geological history. Its relative isolation from continental areas with similar climates and greater topographic diversity are known to be factors in the evolutionary diversification 
of species in the island (Beehler 2007). In terms of ecosystem diversity, Petocz (1987) classified Papua into six major ecosystem types: mangrove, wetland, lowland rainforest, mid-mountainous forest, mountainous forest, and alpine ecosystem, while others have classified Papua into as high as 12 different ecosystem types (Marshall 2007). Moreover, the World Wildlife Fund for Nature classified New Guinea into 15 forest and aquatic ecoregions, each with its own characteristics (BAPPENAS 2003). Therefore, the island has more diverse ecosystems than any other region in Indonesia.

However, Papua is facing rapid and poorly-planned social and economic development, which greatly accelerated when the central government granted special autonomy to Papua in 2001. This rapid and often unplanned development has increased habitat degradation in Papua, negatively impacting its unique biodiversity and natural ecosystems, as well as the developments themselves.

From 2001 to 2003, Papua saw a significant increase in its number of regencies, from just 12 to 26 (BP3D Provinsi Papua 2003). In 2006, two separate provinces were created within Papua, named Papua and Papua Barat. Since then, there has been an increase in the number of regencies in Papua Province to 28, along with the addition of a single municipality (BPS Provinsi Papua 2012). Papua Barat, meanwhile, has increased from three regencies to 10 , along with establishing one municipality (BPS Provinsi Papua Barat 2012). This means the two provinces have a combined 38 regencies and two municipalities. Development of new regencies results in new land and forest clearings for development infrastructure, new roads, and new urban centers. Some new regencies have been built in areas designated as protected areas or priority areas for biological conservation. One example is Tamrau Regency in Papua Barat Province, of which a part belongs to Tamrau Mountain Nature Reserve.

A study in 2001-2002 on deforestation in Papua revealed that Papuan forests had degraded significantly since special autonomy was granted. From 1986 to 1998, the size of Papua's forests was reported to have decreased by 
$0.2 \%(67,000 \mathrm{ha})$, or approximately $0.01 \%(5,500 \mathrm{ha})$ per year (Sumantri 2002). From 1998 to 2000, this increased nearly sixtyfold to $11.7 \%$ (4.9 million ha), or $5.8 \%$ (2.45 million ha) per year (Sumantri 2002). Another important factor that threatens Papuan biodiversity and natural ecosystems is population growth. The average rate of population growth in Papua Province from 1971-1980 was 2.6\%. This increased to $3.46 \%$ in $1980-1990$, while from $1990-2000$, it was $3.18 \%$ (BP3D and BPS Provinsi Papua 2003). There was a significant increase from 20002010, to 5.46\%, the highest in Indonesia (BPS 2010). Population growth creates pressure on the environment, causing further habitat destruction.

The Indonesian government has made conservation efforts to protect Papua's natural ecosystems since the early-1980s, through the National Conservation Plan for Indonesia. Through this plan, at least 54 areas that cover about $20 \%$ of Papua's terrestrial and aquatic habitats have been designated as conservation areas and managed by various management regimes (de Fretes 2007).

However, the 1980 National Conservation Plan was designed to address habitat threats at that time, and the data and proposed management strategies have since become outdated. The areas determined as protected areas were based only on the most popular taxa, such as plants, mammals, and birds. Since then, only a handful of protected areas have been effectively managed. It is arguable that the plan is not sufficient to address the current threats to Papua's biodiversity.

If the current trend of habitat degradation in Papua continues, future research on the biology and ecology of Papua's species will be hindered. This includes species found in both remote or isolated areas and urban centers. Based on various assessments of conservation prioritization in Papua by Conservation International (1999) and Polhemus et al. (2004), many endemic species with very narrow distribution ranges were observed near urban centers, such as some rainbowfish species (Chilatherina sentaniensis, Glossolepis incisus, Melanotaenia ajamaruensis, Melanotaenia boesemani). Thus, the current governmental development that is centered in urban areas has directly threatened many 
endemic species, especially those with a narrow distribution area. Species like endemic freshwater fishes are among the most threatened groups in Papua, with very limited distribution and low dispersal ability. Furthermore, these freshwater fishes are sensitive to habitat alteration, making them particularly vulnerable to further unplanned development.

The rainbowfishes (family Melanotaeniidae) are one of the endemic freshwater fish groups with some members identified to be threatened species (IUCN 2012). Two such species are the Red Rainbowfish (Glossolepis incisus) and the Sentani Rainbowfish (Chilatherina sentaniensis), whose distributions are known to be limited to Lake Sentani in Jayapura and its tributaries. Both species have become threatened as a result of human activities around Lake Sentani. The IUCN Red List assessment in 1996 listed the conservation status of the Red Rainbowfish as Vulnerable and the Sentani Rainbowfish as Critically Endangered (Allen 1996a, 1996b). Both species were determined to be the two out of four mostthreatened endemic rainbowfish species in Papua (Ohee 2005).

The impact of human activities is not only limited to the species, but their habitat, as well: Lake Sentani. Despite the fact that Lake Sentani has been identified as an important ecosystem for species conservation (Conservation International 1999; Polhemus et al. 2004), the area remains under no protection. Meanwhile, human activities surrounding the lake have led to noticeable deforestation around it, water pollution, and the introduction of exotic species.

The Red Rainbowfish was discovered in 1907, and there has been very limited information on the species since then. Allen in 1996 reported the most recent information on the species as a base for the IUCN conservation assessment. As this information was general, however, no detailed ecological information on the species exists, let alone the impact of human activities on its fate, despite the fact that the Red Rainbowfish (along with other endemic species found in the lake) is located in Jayapura, the capital city of Papua Province. Furthermore, the Sentani Rainbowfish is the most threatened rainbowfish according to the IUCN Red List because of habitat pollution and the 
introduction of exotic species. This fish was found in one of the tributaries of Lake Sentani-Jembatan II Creek, around $12 \mathrm{~km}$ southwest of Jayapura-until approximately the early-2000s, when the habitat became turbid because of small-scale gold mining in its headwaters. In 2006, it was found in another tributary, Mekaye creek, around $14 \mathrm{~km}$ east of Jayapura, but has not been found there recently. It is believed to be extinct in Lake Sentani. Therefore, our research was on the Red Rainbowfish in Lake Sentani, only.

\subsection{Research Objectives}

Freshwater fish in Papua are an example of the spectrum of threats and vulnerabilities; they are endemic and sensitive to a broad array of environmental deteriorations, have low dispersal ability, have their habitats encroached upon by urban development, and are attractive for trade. Therefore, research on the ecology of freshwater fishes and strategies on their conservation is urgently required. Papua has a high level of freshwater fish species diversity and endemicity, making it important to document the various aspects of these species, one of which is the rainbowfish.

This study aims to document the ecology of the Red Rainbowfish, one of the less known species, and the impact of human activities on its habitats in Lake Sentani, Papua. The decision to study the impact of habitat degradation on rainbowfishes in Papua was based on these considerations: 1) the rainbowfish has conservation appeal because of its wide variation in color and body shape; 2) it is vulnerable to extinction (because it has restricted range); and 3) it is believed to be sensitive to water pollution.

Specifically, this study was designed to focus on the impact of human activities on: 1) the presence and absence of the Red Rainbowfish; 2) the sex ratio of the species; 3 ) the fish body length; 4) the presence and absence of introduced species; and 5) the fish abundance (rainbowfish vs. introduced species) in various parts of the lake based on the level of human impact. 


\section{Ecology of the Red Rainbowfish and the Impact of Human Activities on Its Habitats}

\subsection{The New Guinea Freshwater Fishes}

\subsubsection{Biodiversity of Freshwater Fishes in New Guinea Island}

Although New Guinea has been acknowledged to have one of the most diverse marine fish fauna on Earth, only about 329 freshwater fish species have been recorded. Of this total, 13 species are introduced and about 102 are marineoriginated species. The 102 species are secondary division fishes, with distribution limited to New Guinea and its satellite islands, while the other 214 are primary division fishes, with a wide distribution outside of New Guinea (Allen 1991). The total number of freshwater fish species in New Guinea remains unknown. A field survey in 2002 increased the species number to 385 (Allen et al. 2002). New Guinea has a high level of freshwater fish endemism (about 60\%) (Allen et al. 2002). Around 35 freshwater species are shared with Northern Australia, indicating that these two areas were once connected. The freshwater fishes of New Guinea and Australia are very unique, and are mostly secondary division fishes, having evolved from marine species, whereas other continents' freshwater fishes are primary division fishes (Allen 1991).

The freshwater fishes of New Guinea are distributed in various habitats, including lowland rivers, floodplain lakes, swamps, upland lakes, torrential mountain streams, and coastal streams (Allen 1991).

\subsubsection{Status and Conservation Measures of Freshwater Fishes}

As with many parts of Indonesia, fish habitats in New Guinea are facing rapid habitat degradation as the result of rapid human population growth, large-scale infrastructure development, pollution, domestic waste, and deforestation. Papua still has extensive natural ecosystems, but between 1993 and 1997, forests and other natural ecosystems were reduced significantly (Conservation International 1999). Habitat loss because of larger-scale developments such as plantations, 
mining, introduction of new regencies, and logging have threatened much of Papua's unique biological ecosystems, including its freshwater ecosystems. Polhemus et al. (2004) stated that there are three main threats to freshwater ecosystems in New Guinea: 1) habitat alteration; 2) use of biotic resources; and 3) invasive species. As a result of these threats, some freshwater fishes have been listed in the IUCN Red List with various conservation statuses, and some have become very rare. One example is Pristis microdon, which is distributed in the tropical Indo-West Pacific, and commonly observed in the Digul, middle Fly, middle and lower Sepik, and Ramu Rivers, as well as Lake Sentani, where FAO (1972) reported it to have become rare. The species is listed in the IUCN Red List as Critically Endangered (Compagno et al. 2006), along with being listed as a protected species in Indonesia. Many freshwater fish groups with restricted distribution ranges have suffered, such as the rainbowfishes (Melanotaeniidae) and blue-eyes (Pseudomugilidae). For instance, Chilatherina sentaniensis, which is listed as Critically Endangered in the IUCN Red List, meaning it is at high risk of extinction (Allen 1996a), is a striking example of the described threats. The species was reported to occur only in Lake Sentani and its tributaries. It was collected in a tributary stream flowing into the northeastern end until early2000 , as well as in a tributary about $14 \mathrm{~km}$ east of Jayapura until 2006. Recent surveys, however, have failed to observe the species in these locations. It is likely that habitat degradation is the cause. Another species, Melanotaenia boesemani, is found in the Ayamaru Lakes region in the center of the Bird's Head Peninsula, and is listed as Endangered (Allen 1996c). Both C. sentaniensis and M. boesemani are the most threatened rainbowfish species in Papua. Many other species are listed as Vulnerable, but their proper conservation status cannot be determined because of a lack of data. These are Glossolepis incisus (Allen 1996b), Chilatherina bleheri (Allen 1996d), and Melanotaenia parva (Allen 1996e).

In an effort to conserve Papua's biodiversity, Conservation International (1999) determined 23 freshwater habitats as a priority for freshwater conservation in Papua. Polhemus et al. (2004) determined about 40 areas of 
freshwater endemism in New Guinea and nearby islands, and grouped them into six broad regions based on three groups of freshwater biota: fish, crayfish and aquatic insects. Genus Melanotaenia was used as an indicator for the classification of endemic freshwater fishes in New Guinea. Generally, rainbowfishes have a restricted and well-defined distribution area. The smallest known distribution area ever recorded is less than one ha in Lake Kurumoi in Bintuni Bay (Kadarusman et al. 2010), belonging to Melanotaenia parva, where it is only found. Meanwhile, the largest distribution area is approximately 2.6 million ha, located in the Bird's Head and Bomberai Peninsulas, and the known habitat of Melanotaenia irianjaya (Ohee 2005).

A gap analysis on the designated conservation areas and rainbowfish distribution in Papua revealed that the distribution area of 30 endemic rainbowfish species of Papua is part of 11 out of 23 conservation priorities of freshwater ecosystems that were identified by Conservation International in 1999 (Ohee 2005; Conservation International 1999). Further gap analysis also showed that many of the distribution areas of the rainbowfish were located outside of the protected areas in Papua. Only 16 out of 30 endemic species distribution areas were covered under the existing designated conservation areas in Papua. However, only a small proportion (27\%) of the distribution areas was inside the existing designated conservation areas, while $73 \%$ of the distribution areas were outside of the conservation areas. One concern is that some of these protected areas still have "proposed" statuses (meaning they are not legally protected), and therefore can be threatened by habitat conversion. Furthermore, some rainbowfish habitats are found in exploited forested regions, whether for mining, plantation, logging, or road development. Habitats belonging to many endangered rainbowfish species are located outside of existing protected areas. Examples include Lake Sentani, which is the habitat of Chilatherina sentaniensis and Glossolepis incisus, and Kurumoi Lake, which is the habitat of Melanotaenia parva (Ohee 2005). 


\subsubsection{New Discoveries}

Freshwater fish fauna-and rainbowfishes in New Guinea in particular-were poorly understood until the past decade, after an increase in field surveys in Papua (Allen et al. 2002; Mack and Alonso 2002; Richards and Suryadi 2000; Watson and Allen 1999; Allen and Renyaan 1995, 1996a, 1996b, 1998a, 1998b, 2000a, 2000b). The most recent discoveries of other fish species are Sicyopterus sp. (Gobiidae), discovered in 1998 in Wapoga, Northern New Guinea (Allen and Renyaan 2000a), and Lentipes multiradiatus (Gobiidae), which was discovered in 2000 in a small pond in Yongsu village, in the foothills of the Cyclops Mountains (Allen et al. 2002, Allen 2001).

Prior to 1975, family Melanotaeniidae (rainbowfish) contained only 26 species (Allen 1998), and by 2011, 79 species were known. A year later, a further five species were identified, namely Chilatherina pagwiensis (Allen and Unmack 2012), which is only found in Papua New Guinea, and Melanotaenia arguni, $M$. urisa, M. veoliae, and M. wanoma (Kadarusman et al. 2012), which are only found in Papua. Allen, the leading freshwater fish taxonomist, recorded at least 43 species in his book in 1991; eight of them Chilatherina species, six Glossolepis species, one Iriatherina species, and 28 of them Melanotaenia species. Five more unnamed species were later recorded (Allen 1995). Between 1980 and 1998, 23 rainbowfish species were discovered in New Guinea (Allen 1998). More recently, four Melanotaenia species from Papua and one Chilatherina species from Papua New Guinea were identified (Kadarusman et al. 2012; Allen and Unmack 2012). New species of rainbowfish continue to be discovered in New Guinea, and especially in Papua (Allen and Hadiaty 2011; Kadarusman et al. 2010, 2011, 2012; Allen et al. 2008; Allen and Unmack 2008).

\subsection{The Ecology of the Red Rainbowfish}

The rainbowfishes belong to family Melanotaeniidae and are restricted to New Guinea and eastern and northern Australia. They are one of the ornamental 
fishes because of their attractive colors, harmlessness to other fish, and ease with which they are bred in captivity (Allen 1991, 1995; Allen and Cross 1980, 1982). Melanotaeniidae belongs to the Atheriniformes order (Nelson 2006), and has a close relationship to Pseudomugilidae as the sister group (Saeed et al. 1989). They evolved from a marine atherinid ancestor (Allen 1980). Melanotaeniidae consists of 84 species in seven genera, the largest of which is Melanotaenia, with 60 species (Fig. 2.1).

\subsubsection{Distribution}

New Guinea is a geologically young island, with mountains that cut across it, separating the north from the south and consequently creating an effective barrier that has isolated rainbowfish populations. The species on each side are also very distinctive. Only Chilatherina campsi is found on both sides of the Central Dividing Range (Allen 1991, 1995).

Rainbowfish distribution is differentiated into three biogeography provinces: northern, western, and southern New Guinea/Australia. Northern New Guinea is believed to be a distinct biogeographic region for freshwater fishes (McGuigan et al. 2000; Allen and Cross 1982). Western New Guinea consists of the Bird's Head Peninsula and the nearby islands of Waigeo and Batanta. This province was identified as a center of rainbowfish diversity (Allen 1995). The northern and western biogeographic regions are not part of the Australian craton, while the third biogeographic region's two parts, southern New Guinea and Australia, have a close biogeographic relationship, and thus some species found in southern New Guinea are also found in northern Australia (McGuigan et al. 2000; Allen 1991, 1995; Allen and Cross 1982). Allen (1991) also classified the rainbowfishes, and in particular the largest genus, Melanotaenia, into four different areas: Melanotaenia from the Bird's Head and Bomberai Peninsulas, Melanotaenia from the islands off Papua, Melanotaenia from Northern New Guinea, and Melanotaenia from Southern New Guinea. 
There are seven rainbowfish genera distributed in New Guinea Island and Australia (Fig. 2.1, Table 2.1). The largest genus, Melanotaenia, is found in New Guinea and Australia, along with Iriatherina. Genera Chilatherina, Glossolepis, and Pelangia are restricted to New Guinea. Cairnsichthys and Rhadinocentrus are only found in Australia.

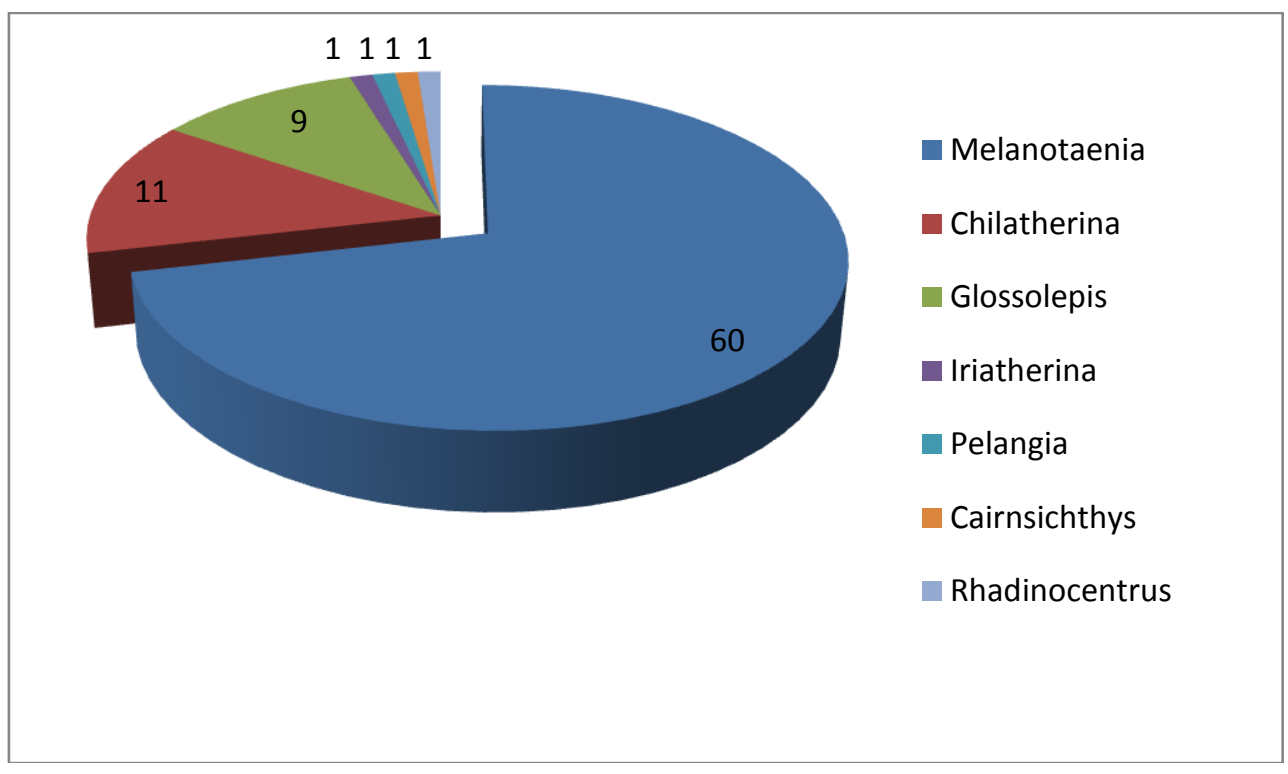

Fig. 2.1. The distribution of number of rainbowfishes species per genus.

There are 84 species currently recognized as Melanotaeniids; 16 of them found only in Australia, 65 in New Guinea, and three (Iriatherina werneri, Melanotaenia maccullochi, and M. rubrostriata) in both Australia and New Guinea (Allen and Cross 1982). Of the 65 Melanotaeniids in New Guinea, 47 are found in Papua (40 of which are endemic) and 27 are found in Papua New Guinea (20 of which are endemic; Fig. 2.2, Table 2.1). The 40 rainbowfish species found only in Papua were discovered mostly in the north, west, and Bird's Head Peninsula, with distributions restricted to one lake, and some ponds, rivers, and tributaries. They encompass four species of genus Chilatherina, five species of genus Glossolepis, 30 species of genus Melanotaenia, and one species of genus Pelangia (Allen 1991, 1995, 1998; Allen et al. 2008; Allen and Hadiaty, 2011; Allen and Unmack 2008; Kadarusman et al. 2010, 2011, 2012; Table 2.1, Appendix 1). 
A previous study by Ohee (2005) found that of Papua's 30 endemic rainbowfish species, the distribution area of 13 species ranged from 0.1 to 2.6 million ha, and six species from 10,000 to 100,000 ha, while the remaining 11 species had the smallest distribution area with less than 10,000 ha. Most of them were restricted to a single lake. For instance, Melanotaenia parva was restricted to Lake Kurumoi in the Bird's Head Peninsula; Melanotaenia ajamaruensis and M. boesemani was known only from the Ayamaru Lakes, also located in the Bird's Head Peninsula; and Chilatherina bleheri was discovered only in Lake Holmes (Danau Bira) in the lower Mamberamo River (Allen 1991). There were few species known to be widespread in Papua, such as Melanotaenia vanheurni, which occurred in creeks, tributaries, and streams in Buare, and was also observed in Mamberamo River (Tim Peneliti Biologi UNCEN 2008).

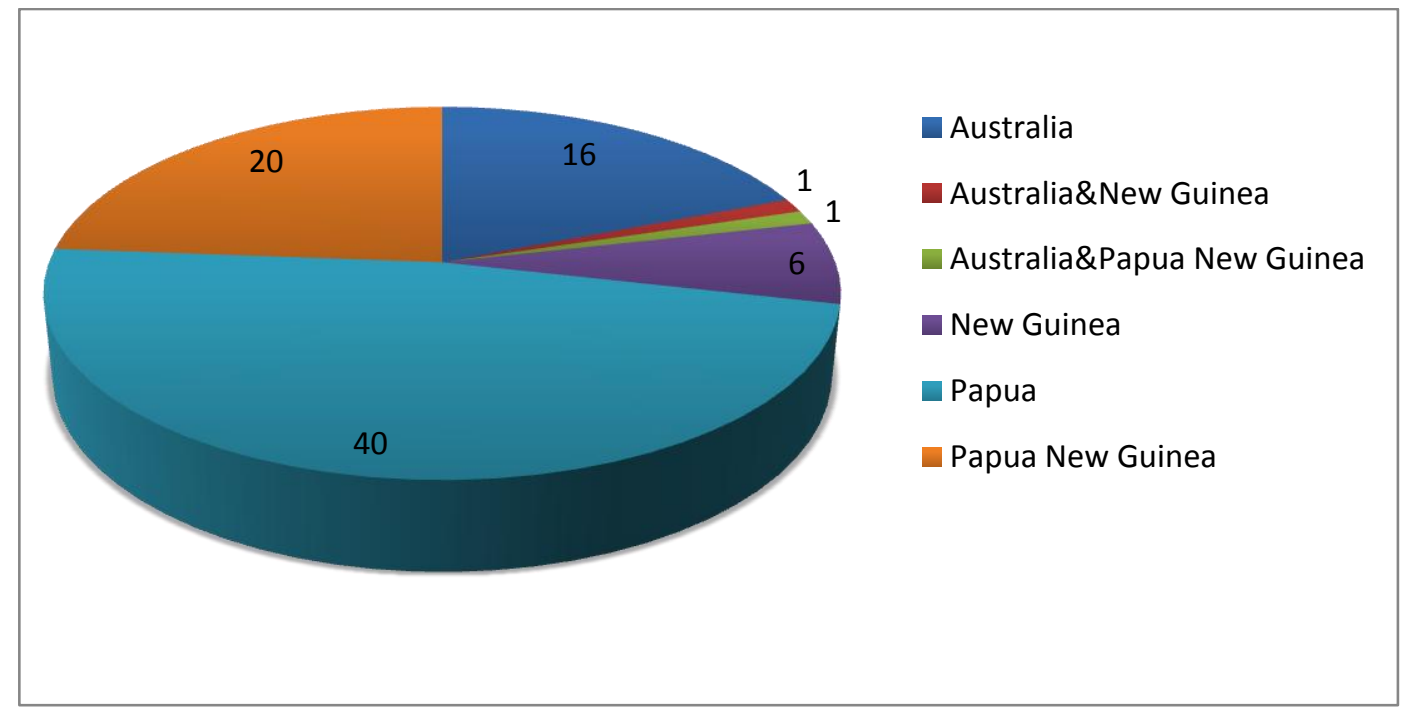

Fig. 2.2. Numbers of rainbowfish species in New Guinea and Australia.

Twenty-one rainbowfish species in Papua can be divided into two groups: a northern and a southern group. The northern group comprises 19 species from four genera. Three genera, Glossolepis, Chilatherina, and Pelangia, are unique to this region, while genus Melanotaenia can also be found in Australia. The southern group consists of two species, one each belonging to Melanotaenia and Iriatherina. The 26 species, which belong to genera Melanotaenia and 
Chilatherina, are known to inhabit Western New Guinea, including the Bomberai and Bird's Head Peninsulas and Raja Ampat Islands (Allen 1991, 1995). The distribution of rainbowfish species in Papua can be seen in Appendix 1. The Bird's Head region (including the nearby Raja Ampat Islands and the Bomberai Peninsula) is believed to be a center of diversity for Melanotaenia species (McGuigan et al. 2000; Allen 1995). Currently, 15 species have been described from this region: Melanotaenia ajamaruensis Allen and Cross, 1980, M. ammeri Allen, Unmack \& Hadiaty, 2008, M. angfa Allen, 1990, M. arfakensis, Allen, 1990, M. batanta Allen \& Renyaan, 1996, M. boesemani Allen and Cross, 1980, $M$. catherinae De Beaufort, 1919, M. fasinensis Kadarusman, Sudarto, Paradis \& Pouyaud, 2010, M. fredericki Fowler, 1939, M. irianjaya Allen, 1985, M. kokasensis Allen, Unmack \& Hadiaty, 2008, M. misoolensis Allen, 1982, M. parva Allen, 1990, M. salawati Kadarusman, Sudarto, Slembrouck \& Pouyaud, 2011, and M. synergos Allen \& Unmack 2008 (Kadarusman et al. 2012).

\subsubsection{Habitat}

Rainbowfishes are usually less than $12 \mathrm{~cm} \mathrm{SL} \mathrm{(standard} \mathrm{length)} \mathrm{in} \mathrm{body} \mathrm{length.}$ They occur mostly in freshwater habitats below an elevation of $1500 \mathrm{~m}$ a.s.l. (Allen 1991). They are found in a variety of habitats, including streams of all sizes, lakes, ponds, reservoirs, and swamps, but many species are often restricted to a single, isolated lake, or small section of a particular river system (Allen 1995; Allen and Cross 1982).

Lake-dwelling species reside in the lake edge, shoaling amongst the submerged grass, water plants, dead wood, and leaves. Some species prefer creeks, streams, or rivers with fast-flowing and clear water, living on a boulder or gravel substrate, while some occupy a sand and silt substrate. Other species prefer estuaries, especially in the mouth of a river that flows into the sea. Along the water body, the riparian vegetation varies, with many kinds of trees, shrubs, 
Table 2.1. Rainbowfish genera and number of species per genus.

\begin{tabular}{|c|c|c|c|c|c|c|c|c|c|c|}
\hline \multirow[b]{2}{*}{ No. } & \multirow[b]{2}{*}{ Region } & \multicolumn{7}{|c|}{ Genus } & \multirow{2}{*}{$\begin{array}{r}\text { Total Number } \\
\text { of Species }\end{array}$} & \multirow[b]{2}{*}{ Remarks } \\
\hline & & Carinsichthys & Chilatherina & Glossolepis & Iriatherina & Melanotaenia & Pelangia & Rhadinocentrus & & \\
\hline 1 & $\begin{array}{l}\text { Australia and } \\
\text { New Guinea }\end{array}$ & 0 & 0 & 0 & 1 & 1 & 0 & 0 & 2 & $\begin{array}{l}\text { Iriatherina werneri, } \\
\text { Melanotaenia rubostriata }\end{array}$ \\
\hline 2 & $\begin{array}{l}\text { Australia and } \\
\text { Papua New } \\
\text { Guinea }\end{array}$ & 0 & 0 & 0 & 0 & 1 & 0 & 0 & 1 & M. macculochi \\
\hline 3 & New Guinea & 0 & 3 & 0 & 0 & 2 & 0 & 0 & 5 & $\begin{array}{l}\text { Chilatherina crassispinosa, } \\
\text { C. fasciata, } \\
\text { C.lorentzi, } \\
\text { M. affinis, } \\
\text { M. goldiei }\end{array}$ \\
\hline 4 & Australia & 1 & 0 & 0 & 0 & 14 & 0 & 1 & 16 & \\
\hline 5 & Papua & 0 & 4 & 5 & 0 & 30 & 1 & 0 & 40 & \\
\hline 6 & $\begin{array}{l}\text { Papua New } \\
\text { Guinea }\end{array}$ & 0 & 4 & 4 & 0 & 12 & 0 & 0 & 20 & \\
\hline & Total & 1 & 11 & 9 & 1 & 60 & 1 & 1 & 84 & \\
\hline
\end{tabular}

Sources: Allen 1991, 1995, 1998; Allen and Renyaan 1995, 1996a, 1996b, 1998a, 1998b, 2000a, 2000b; Allen et al. 2008; Allen and Hadiaty 2011; Allen and Unmack 2008; Kadarusman et al. 2010, 2011, 2012; Mack and Alonso 2000; Richards and Suryadi 2002. 


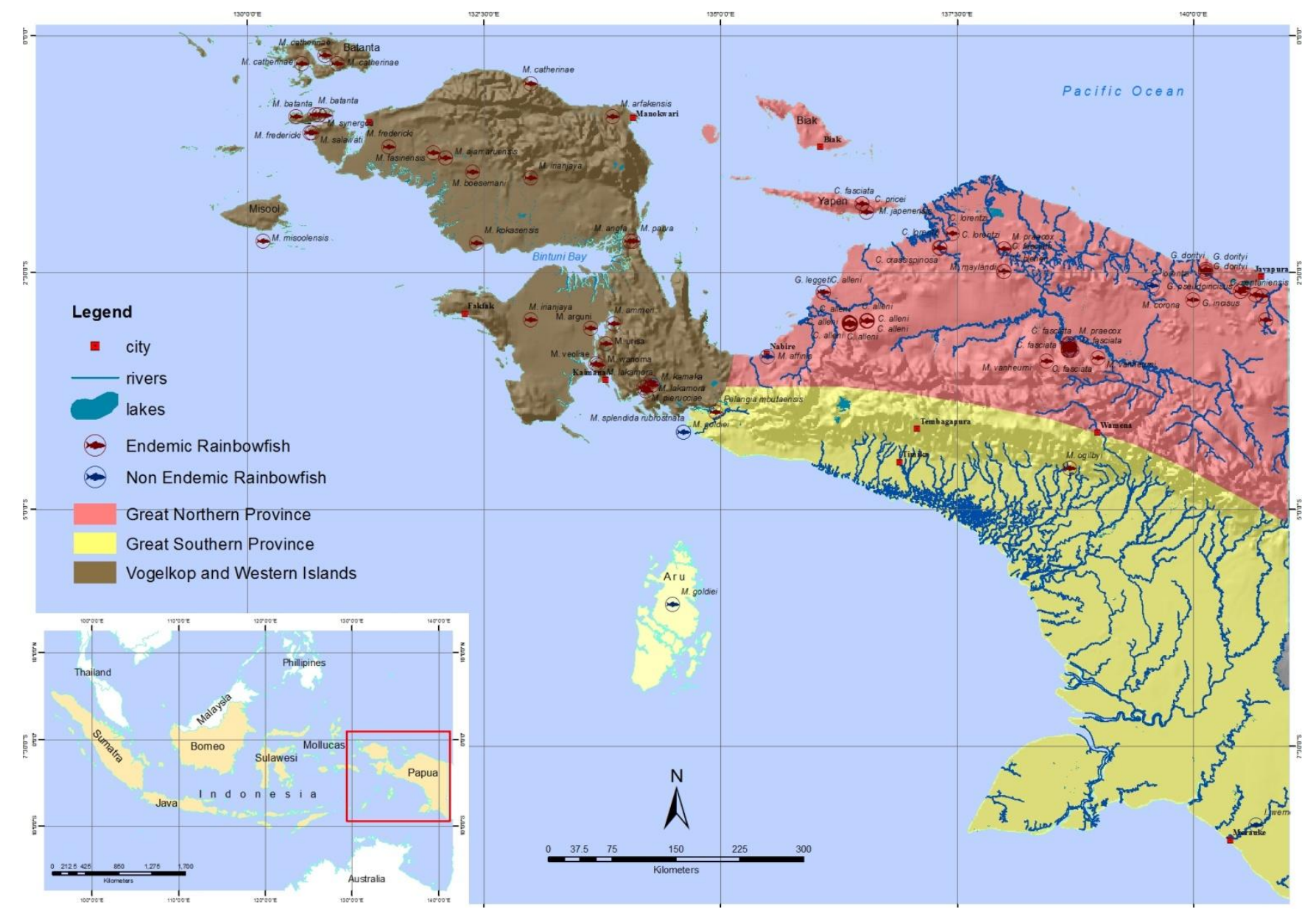

Fig. 2.3. Distribution of 47 rainbowfish species in Papua, which includes 40 species endemic to Papua, five New Guinean species, and two New Guinean and Australian species. 
and grasses, shading the habitats of the fish, and serving as a food source for the fish (Allen 1995).

The Red Rainbowfish is a lake-dwelling species, and found along the edge of Lake Sentani, around riparian and aquatic vegetation. It mostly occupies water less than two meters deep, but can be found in deeper parts of the lake. The species can also be observed a few meters into some of Lake Sentani's tributaries. It occupies the same habitat as some other species, such as Chilatherina fasciata (Barred Rainbowfish), Giurus margaritaceus (Snakehead Gudgeon), as well as some juveniles of introduced species like Oreochromis mossambicus (Mozambique Tilapia).

\subsubsection{Diet}

The rainbowfishes' diet includes a variety of plant and animal items including algae, ants, aquatic insect larvae, tiny fruits, filamentous algae, and small crustaceans (Allen 1991; Allen and Cross 1982). They are also known to be opportunistic feeders (Hieronimus 2002).

The specific diets of most New Guinean rainbowfishes are presently unknown. As there is more and better data on the biological aspects of Australian rainbowfishes, however, their diets are more well-known. Examples include the Ornate Rainbowfish (Rhadinocentrus ornatus), which is a microphagic carnivore, and the Eastern Rainbowfish (Melanotaenia splendida splendida), which is omnivorous. Much of the Ornate Rainbowfish's diet comprises aquatic insects and their aerial forms, terrestrial invertebrates, such as Diptera, Hymenoptera, and Hemiptera, micro and macrocrustaceans, and fragments of terrestrial vegetation. The Eastern Rainbowfish, meanwhile, feeds on small aquatic invertebrates, aerial forms of aquatic insects (ants, in particular), and aquatic macrophytes. Its major diet, however, is algae, with diatoms and filamentous algae being the most important components (Pusey et al. 2004).

Unlike some other rainbowfish species, little information or records exist on the diet of the Red Rainbowfish. Field studies and observations in aquariums 
report that genus Glossolepis is omnivorous (Allen 1991, Hieronimus 2002). The Red Rainbowfish is only known to feed on aquatic insects and algae; in captivity, the species is fed commercial flake food, frozen daphnia, mosquito larvae, and pellet food (Johannes Graf, pers. comm.).

\subsubsection{Reproduction}

Rainbowfishes spawn throughout the year, with the highest rate of birth occurring during the early rainy season. Eggs are deposited daily on the upperside of the leaves of aquatic vegetation, hatching within 7-18 days. Based on an aquarium study, a rainbowfish generally reaches sexual maturity within the first year (Allen 1991). Other aquarium studies revealed that most species spawned in the morning, while a minority of them spawned at other times. Larger individuals are known to spawn more eggs than smaller individuals (Hieronimus 2002).

\subsubsection{Ecological Roles}

Rainbowfishes play an important role in the freshwater communities of Australia and New Guinea. The family is a food source for bigger fish, and, more importantly, a controlling agent of mosquito larvae, which carry malaria, a very common disease in New Guinea. In the 1970s, the Indonesian government introduced exotic guppies into some freshwater ecosystems in Papua for mosquito control. Instead of controlling mosquito populations, however, the guppies were less effective than rainbowfishes and competed with them for available space and food resources (Allen and Cross 1982).

\subsection{Human Impact around Lake Sentani and Its Threats to the Rainbowfish}

Lake Sentani, with its high endemism of freshwater biota (Polhemus et al. 2004), is listed as a priority area for the conservation of freshwater ecosystems by Conservation International (1999). Lake Sentani is approximately 9,360 ha in size 
and 2-24 km wide. The greatest recorded depth is $51.8 \mathrm{~m}$, in the western part of the lake. The lake is located in Jayapura Regency $\left(2^{0} 33^{\prime}-2^{0} 41^{\prime} \mathrm{S}, 140^{\circ} 23^{\prime}-\right.$ $\left.140^{\circ} 38^{\prime} \mathrm{E}\right), 70-90$ meters above sea level. About 14 creeks flow through the lake with a watershed size of around $600 \mathrm{~km}^{2}$ and it has only one outlet, the Djafuri Stream, which is located in the southern part of the lake (Puay area). The substrate of the lake consists of mud and sand, and water plants grow in shallow areas to cover $25 \%$ of the lake's area. Pandanus and Sago (Metroxylon sp.) grow on the shore (Umar et al. 2005; Bapedalda Provinsi Papua dan LPPM-ITB 2004; Howard 1987; FAO 1972).

The organisms living in the lake comprise water plants, mollusks, crustaceans, and fish. The latter three are commonly caught and sold in the market, and consumed for their protein. Hydrilla, Elodea, Ceratophyllum, Myriophyllum, Potamogeton, and Vallisneria are some aquatic plants found in the deeper parts of the lake, while water lilies (Nymphae), Bulrushea, and floating aquatic plants Pistis and Lemna are found in the shallow parts (FAO 1972). There is a lack of data on the crustacean species in the lake. FAO (1972) recorded at least three species of crustaceans: shrimp, crayfish, and freshwater crab. Br. Surbakti and Ramandey (2010) recorded 14 species of mollusks in Lake Sentani, six inlet streams, and Djafuri Stream. Fish communities from Lake Sentani include endemic, native, anadromous, and introduced species. Chilatherina sentaniensis, Glossolepis incisus (family Melanotaeniidae), and Glossogobius sp. (family Gobiidae) are three endemic fishes, while Oxyeleotris heterodon, Giurus margaritaceus (family Eleotridae), Glossamia wichmanni and G. beauforti (family Apogonidae) are some indigenous species. Pristis microdon (familiy Pristidae) and Mugil cephalus (family Mugilidae) are two out of eight species that are anadromous; that is, they are born in freshwater, but spend most of their life in marine water, before returning to freshwater to spawn.

Approximately $60 \%$ of the lake area is inhabitated by humans, most of which are fishermen. There are 24 villages spread around the shore and the small islands 
found in and around the lake (Umar et al. 2005; Bapedalda Provinsi Papua dan Lembaga Penelitian dan LPPM-ITB 2004). The people living around the lake used it for their daily needs, both as a water source and for subsistence actvities like fishing. These activities polluted the lake and changed its biota, however. Simbala (2002) studied the level of water pollution in Lake Sentani and found that the major sources of pollution sources were human settlements, livestock, and the traditional market. Other pollution sources included outboard motors, chemicals from washing, and some small-scale organic materials from the settlements surrounding the lake. These pollutants have decreased Lake Sentani's water quality and resulted in the water not being suitable for drinking without proper treatment.

Other serious threats come from introduced species, and exotic freshwater fishes, in particular. Sukarwo (1990) recorded at least 39 species of aquatic plants in Lake Sentani, six of which were aquatic weeds (Eichhornia crassipes, Hydrilla verticillata, Ceratophyllum demersum, Salvinia molesta, Scirpus grossus, and Panicum repens). These noxious species can grow very fast to occupy shallow shorelines, competing for space with both humans and lakedwelling organisms. Eichhornia crassipes is the most common plant and is found throughout the entirety of Lake Sentani, often disturbing water-based transportation. As early as 1937, small numbers of fish had been stocked in several lakes in Papua, including Lake Sentani. The non-native species were first introduced to provide more protein options for the local population. The early fish species introduced to the lakes in Papua were Cyprinus carpio, Pontius gonionotus, Trichogaster pectoralis, Helostoma temmincki, Osphronemus goramy, and Tilapia spp. (FAO 1972). The introduction of exotic fish species in Lake Sentani continues to this day, both intentionally and accidentally. It has been reported that approximately 17 out of the 34 fish species in Lake Sentani are introduced species (Renyaan 1993; Allen 1991; Allen, pers. comm.), as shown in Table 2.2. These species negatively affect the native species by competing with them for space and food, or by directly feeding on them (Allen 1991). 
Table 2.2. Fishes in Lake Sentani.

\begin{tabular}{|c|c|c|c|c|c|c|c|}
\hline \multirow[b]{2}{*}{ Group } & \multirow[b]{2}{*}{ No. } & \multirow[b]{2}{*}{ Family } & \multirow[b]{2}{*}{ Species (as of December, 2011) } & \multirow[b]{2}{*}{ Local name } & \multicolumn{3}{|c|}{ Remarks } \\
\hline & & & & & $*$ & $* *$ & $* * *$ \\
\hline 1 & 2 & 3 & 4 & 5 & 6 & 7 & 8 \\
\hline \multirow[t]{3}{*}{ Endemic } & 1 & Melanotaeniidae & Chilaterina sentaniensis & Hew/ikan kaskado/ikan pelangi & $\mathrm{X}$ & & \\
\hline & 2 & Melanotaeniidae & Glossolepis incisus & Hew/ikan kaskado/ikan pelangi & & & \\
\hline & 3 & Gobiidae & Glossogobius sp. 10 & Himem & & & \\
\hline \multirow[t]{7}{*}{ Indigenous } & 4 & Ariidae & Arius velutinus & Kanseli & & & \\
\hline & 5 & Plotosidae & Neosilurus novaeguineae & Holiya & $x$ & & \\
\hline & 6 & Eleotrididae & Oxyeleotris heterodon & Kayou (gabus hitam) & & & \\
\hline & 7 & Eleotrididae & Giuris margaritacea & Kahe (gabus merah) & & & \\
\hline & 8 & Chandidae & Glossamia wichmanni & Kandei/gete-gete & & & \\
\hline & 9 & Apogonidae & G. beauforti & Kandei/gete-gete & & & \\
\hline & 10 & Melanotaeniidae & Chilatherina fasciata & Hew/ikan kaskado/ikan pelangi & & & \\
\hline \multirow[t]{7}{*}{ Anadromes } & 11 & Anguillidae & Anguilla australis & Kahilo & & & $x$ \\
\hline & 12 & Anguillidae & A. bicolor & Belut/kahilo & & & $x$ \\
\hline & 13 & Anguillidae & A. marmorata & Belut/kahilo & & & $x$ \\
\hline & 15 & Pristidae & Pristis microdon & Pari Sentani & & $x$ & \\
\hline & 16 & Carangidae & Caranx melampygus & Barra & & & $x$ \\
\hline & 17 & Carangidae & C. ignobilis & Barra & & & $x$ \\
\hline & 18 & Mugilidae & Mugil cephalus & Kaijoko & & & $x$ \\
\hline \multirow[t]{5}{*}{ Introduced } & 19 & Clariidae & Clarias batracus & Lele & & & $x$ \\
\hline & 20 & Channidae & Channa striata & Gabus toraja & & & \\
\hline & 21 & Cyprinidae & Cyprinus carpio & Mas & & & \\
\hline & 22 & Cyprinidae & Cyprinus spp. & Mas & & & $x$ \\
\hline & 23 & Cyprinidae & Puntius gonionotus & Tawes & & & \\
\hline
\end{tabular}


Table 2.2. Fishes in Lake Sentani (continued).

\begin{tabular}{lllll}
\hline 1 & 3 & 4 & 5 \\
\hline 24 & Cyprinidae & Systomus orphoides & Mata merah \\
25 & Cyprinidae & Osteochilus hasseltii & Nilem hijau \\
26 & Cyprinidae & Osteochilus sp. & Nilem merah \\
27 & Helostomatidae & Helostoma temminkii & Tambakan \\
28 & Belontiidae & Trichogaster pectoralis & Sepat siam \\
29 & Osphronemidae & Osphronemus goramy & Gourami \\
30 & Cichlidae & Oreochromis mossambica & Mujair \\
31 & Cichlidae & Oreochromis spp. & Mujair \\
32 & Cichlidae & Oreochromis nilotica & Mujair \\
33 & Poeciliidae & Xiphophorus sp. & Ekor pedang \\
34 & Cichlidae & Amphilophus citrinellus & Lohan merah \\
35 & Cichlidae & Amphilophus longimanus & Lohan hitam
\end{tabular}

*Assumed extinct in the wild.

**Not found anymore in Lake Sentani.

$* * *$ Needs confirmation.

Sources: Renyaan 1993; Allen 1991; Allen, pers. comm. 


\subsection{The Red Rainbowfish: Status and Conservation Efforts}

Glossolepis incisus is an omnivorous (Allen 1991), lake-dwelling rainbowfish from northeastern Papua. First described by Max Weber as early as 1907 (Graf 2010), it is found only in Lake Sentani and small creeks around the edge of the lake (Allen 1995). The Red Rainbowfish shares its habitat with the Sentani Rainbowfish (Chilatherina sentaniensis).

Males have a unique, bright red coloration, often with flecks of silver, while non-active males are brackish red; females and juveniles are drab brown or olive with silvery reflections on the head and sides (Fig. 2.4). In some parts of the lake, the body color is dull or discolored, perhaps because of the water quality. The maximum size of males reaches about $120 \mathrm{~mm} \mathrm{SL}$, while females are usually around $100 \mathrm{~mm} \mathrm{SL}$, although they can grow to about $145 \mathrm{~mm}$ in the wild and 150 $\mathrm{mm}$ in aquariums (Graf 2010; Allen 1991, 1995).

Based on threats to its habitat (in the form of habitat degradation), the IUCN Red List has listed the species as Vulnerable (Allen 1996b).

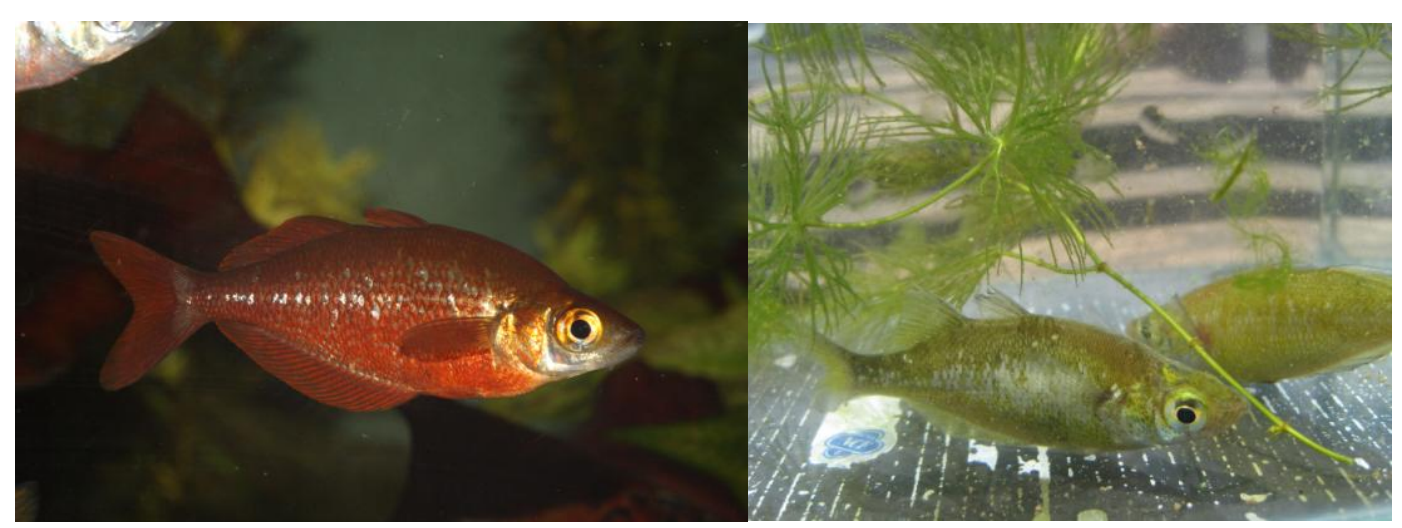

Fig. 2.4. Male (left) and female (right) Glossolepis incisus 


\section{Research Methods}

\subsection{Study Area}

This study was conducted in Lake Sentani (Fig. 3.1). The lake is situated in Jayapura Regency of Papua Province, Indonesia, partly surrounded by the main road leading into Jayapura, the capital of Papua Province, and to Sentani, the capital of Jayapura Regency. There are many human settlements scattered around the lake, either belonging to local communities, who mostly occupy the small islands within the lake, or immigrants from the rest of Indonesia, who live further out from the lake. Human activities around the lake vary, from fishing, bathing, and travelling, to nature tourism and fish farming. The majority of the local communities still use traditional means to fulfill their daily needs, such as fishing. Other activities, such as tourism and fish farming, are mostly conducted by non-locals.

Settlers have impacted the lake significantly and have caused problems with organic and non-organic household wastes, lake sedimentation, and the introduction of non-native species that threaten native species. Some areas of the lake are heavily populated, especially areas near the main road along the east, northeast, and north of the lake, while other areas in the south, west, and northwest have no or low numbers of humans. There are a number of villages of various sizes scattered along the east and northeast end of the lake. Waena Village, for example, is found on the eastern side of the lake, and is 14,024 hectares in size, with a population of 15,738 . Meanwhile, Yabansai Village, also located east of the lake, has a population of 13,000 . Sentani District, on the northeastern end of the lake, comprises 10 small villages that, in total, make up an area of 51,950 hectares and population of 42,259 people. Other smaller villages include Asei Village, located on a small island in the northern part of the lake, 2,160 hectares in size (including some of the shoreline), and with around 400 inhabitants; and Yakonde Village, which is found in the northwest, and is 2,658 hectares in size, with another 400 inhabitants. The average human 
population density around the lake is 6.78 people $/ \mathrm{km}^{2}$, with the greatest density found in the east, northeast, and north of the lake. In Sentani District, the population density is 81.35 people $/ \mathrm{km}^{2}$, while in East Sentani District, the density is 49.15 people $/ \mathrm{km}^{2}$ (BPS Kabupaten Jayapura 2010).

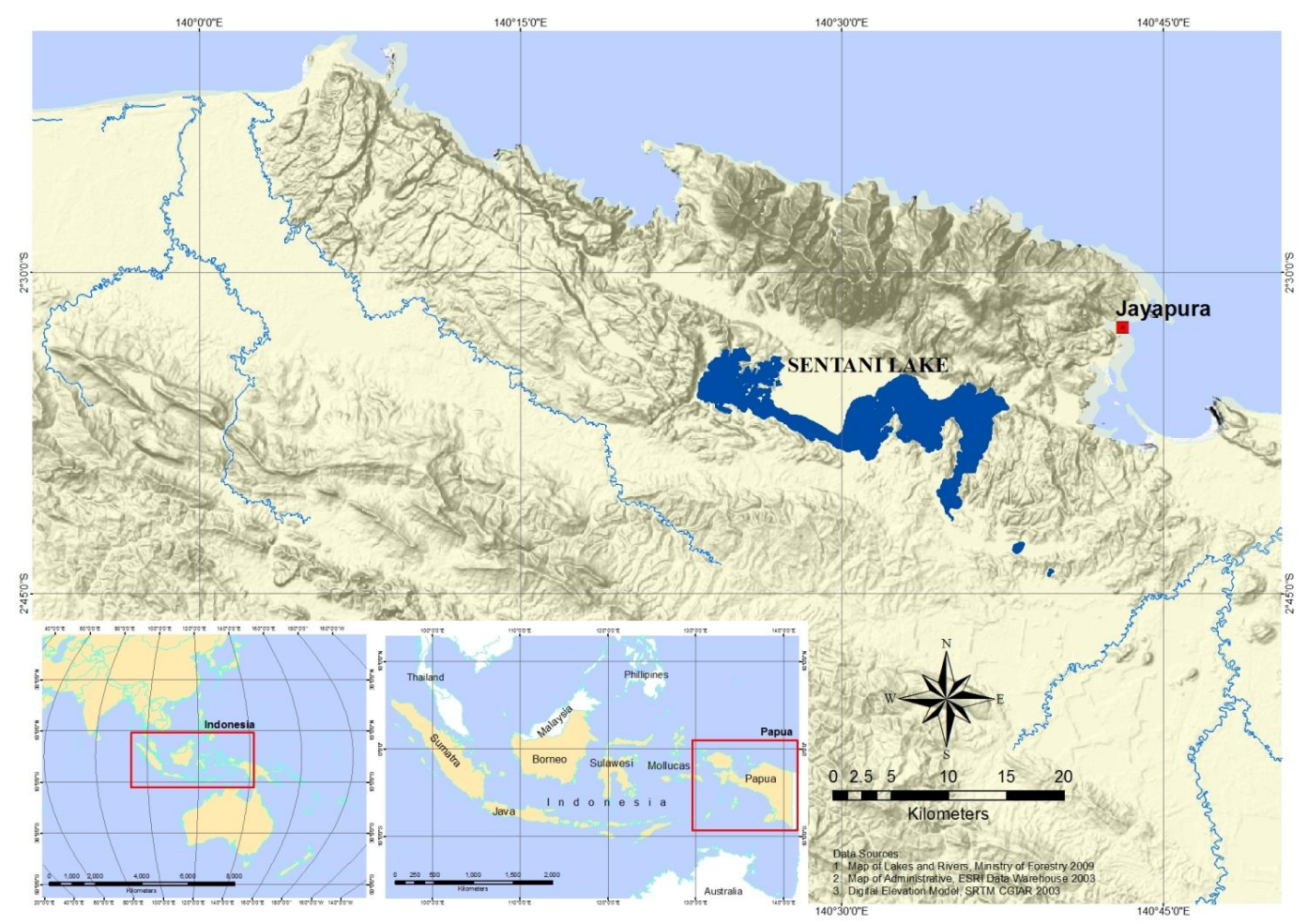

Fig. 3.1. Lake Sentani, one of a number of freshwater ecosystems found in Northern New Guinea Island.

\subsection{Sampling Protocols}

In this study, simple stratified random sampling was used to sample fish and measure water parameters. The study sites were categorized (stratified) into three zones: high level of human activity, medium level of human activity, and low level of human activity. Three locations in each zone were then selected based on their corresponding level of human activity. In each location, three sampling sites with a maximum depth of $1.5 \mathrm{~m}$ were randomly selected. Thus, there were a total nine sampling sites per zone (Fig. 3.2). 


\subsubsection{Sampling Sites}

Based on the level of human activity, the lake was categorized into three zones. The zone with a low level of human activity (Zone III) was regarded as a reference site. Human population density and type of household (traditional vs. modern) were the main considerations when classifying zones. The main criteria for each sampling site were that it had a maximum depth of $1.5 \mathrm{~m}$ and was inhabited by the Red Rainbowfish. Thus, any site exceeding that depth or where no Red Rainbowfish was found was excluded prior to random selection.

\subsubsection{Zone I}

Zone I was defined as a high human impact area, containing the largest villages of the three zones and the highest level of infrastructure. These locations are Waena (AW) as the first location, Jembatan II (AJ) as the second location, and Yoka (AY) as the third location. All three locations are situated in the northeastern part of Lake Sentani (Appendix 2; Appendix 3).

\subsubsection{Zone II}

Zone II was defined as a medium human impact area. The locations of this zone consisted of villages that have been inhabited by traditional communities for over a century, many of whom live in traditional stilt houses. Many families still depend on the lake and its surrounding areas for sustenance. This zone comprised Ayapo (BAy) as the first location, Asei (BAs) as the second location, and Puay (BP) as the third location (Appendix 2; Appendix 3). All but one location is in the northeast of the lake.

\subsubsection{Zone III}

Zone III was defined as a "control area", where the lowest level of human impact was found. Many areas along the lake shoreline remained uninhabited, but contained no rainbowfish populations, and therefore were unsuitable for this research. As a result, unlike Zone I and most of Zone II, locations were situated 
outside of the northeast of the lake; two were in the southeast and one was in the western end, which is much less populated than the northeast. These locations are in Yakonde (CY) as the first location, Rimiyebei (CR) as the second location, and Kanale (CK) as the third location (Appendix 2; Appendix 3). 


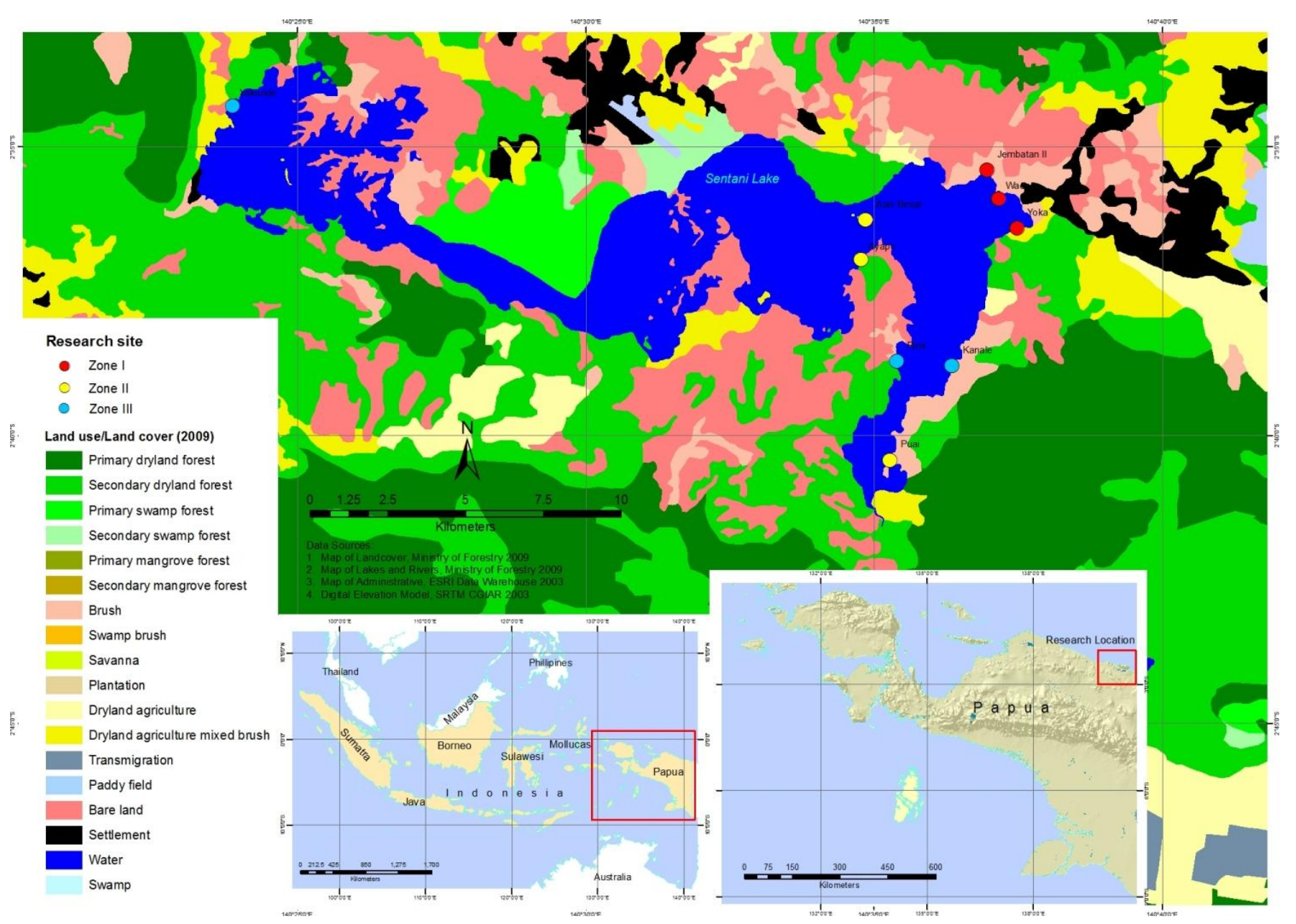

Fig. 3.2. Maps of the research locations. The red circles are the locations of Zone I in the east, the yellow circles are the locations of Zone II in the north and south, and the blue circles are the locations of Zone III in the south and west. 


\subsection{Study Period}

The field study was completed in three years. The first fieldwork was conducted in November-December, 2009; the second July-November, 2010; and the third fieldwork was conducted in October, 2011.

Physicochemical parameters were measured only in the second year (2010). Each location was measured on three different days, resulting in nine data sets per location (Table 3.1).

\subsection{Data Collection}

\subsubsection{Red Rainbowfish Abundance}

Fish were collected along the shoreline at very shallow depths (up to $1.5 \mathrm{~m}$ ) of the lake and mouths of two creeks, namely Waena Creek in AW and Jembatan II Creek in AJ, both of which were in Zone I. One seine net, $3.6 \mathrm{~m}$ length, $1.23 \mathrm{~m}$ in height, and with a mesh size of less than $0.5 \mathrm{~cm}$, was used to collect the fish. With one person holding each end, half of the net was submerged in the water, while four people drove the fish into the net. Fishes were sampled in the morning at each sampling site of a single location. Thus, sampling was conducted a total of three times in one day. Samples were replicated three times on alternate days, yielding 27 data sets for each zone, or 81 data sets for all three zones within a year, and a total 243 data sets in three years (Table 3.1). Sampled Red Rainbowfish were counted and determined by sex. Physical measurements of the standard body length (SL) were from the tip of the upper lip to the posterior end of the vertebral column (Allen 1991), using a manual and digital caliper, before the fish was released. 
Table 3.1. Fish and water sampling periods.

\begin{tabular}{ccccc}
\hline & \multicolumn{4}{c}{ Years/months/activities } \\
\cline { 2 - 5 } & 2009 & \multicolumn{2}{c}{2010} & 2011 \\
\cline { 2 - 5 } & November-December & July-November & October \\
\cline { 2 - 5 } Location & Fish sampling & $\begin{array}{c}\text { Fish } \\
\text { sampling }\end{array}$ & $\begin{array}{c}\text { Water } \\
\text { sampling }\end{array}$ & Fish sampling \\
\hline Zone I & & & & \\
1 & 9 & 9 & 9 & 9 \\
2 & 9 & 9 & 9 & 9 \\
3 & 9 & 9 & 9 & 9 \\
Zone II & & & & \\
1 & 9 & 9 & 9 & 9 \\
2 & 9 & 9 & 9 & 9 \\
3 & 9 & 9 & 9 & 9 \\
Zone II & & & & \\
1 & 9 & 9 & 9 & 9 \\
2 & 9 & 9 & 9 & 9 \\
3 & 9 & 9 & 9 & 9 \\
\hline Total & 81 & 81 & 81 & 81
\end{tabular}

\subsubsection{Physicochemical Parameters}

Water parameters were measured in each location of each zone where fish were sampled. Sampling was conducted three times a day: morning (06.00-09.00 am), midday (11.00 am-13.00 pm), and afternoon (16.00-18.00 pm). Water parameter measurement was repeated three times in each sampling site on three alternate days. Thus, a total of 81 water parameter data sets were collected (Table 3.1). The measured physicochemical parameters included water temperature, water $\mathrm{pH}$, dissolved oxygen (DO), biological oxygen demand (BOD), chemical oxygen demand (COD), nitrate $\left(\mathrm{NO}_{3}{ }^{-}\right)$, nitrite $\left(\mathrm{NO}_{2}{ }^{-}\right)$, and phosphate $\left(\mathrm{PO}_{4}{ }^{3-}\right)$. Water temperature, water $\mathrm{pH}$, and $\mathrm{DO}$ were measured in the field, while the other parameters were measured in the Environmental Laboratory of the Regional Health Laboratory of Papua Province in Jayapura, Papua.

Water samples were collected in Winkler bottles. The water temperatures were measured with the Voltcraft K101 digital thermometer, water pH using a Hanna $\mathrm{HI} 98107 \mathrm{pH}$ tester, and DO was measured using a Lutron DO-5510 oxygen meter. Dissolved oxygen levels in natural and 
wastewaters depend on the physical, chemical, and biochemical activities in the water body (APHA, AWWA, and WPCF 1980). The chemical parameter $\mathrm{BOD}_{5}$ was measured by incubating a water sample in the Aqualytic Liebherr Incubator for five days, at a temperature of $20^{\circ} \mathrm{C}$, with the initial oxygen content having been measured before incubation. The BOD test measures the amount of oxygen required for the biochemical degradation of organic material (carbonaceous demand) and the oxygen used to oxidize inorganic material such as sulfides and ferrous iron (APHA, AWWA, and WPCF 1980). Furthermore, the COD test is a measure of the oxygen equivalent of the organic matter content that is susceptible to oxidation by a strong chemical oxidant (APHA, AWWA, and WPCF 1980). Chemical oxygen demand, as well as nitrate and phosphate, were measured using a Hach DR 2010 spectrophotometer, while nitrite was measured with a GBC UV-Visible spectrophotometer.

\subsubsection{Red Rainbowfish Habitat Characteristics}

The study of Red Rainbowfish habitat characteristics included measuring water quality, water depth, and water turbidity. Substrate types and vegetation were also recorded in the habitats. Water quality was measured as previously described (3.4.2). Water depth was measured in three to four different locations of the sample areas, using a rope that was marked every $50 \mathrm{~cm}$. Results were grouped into three ranges: $0-30 \mathrm{~cm}, 30-60 \mathrm{~cm}$, and $60-120 \mathrm{~cm}$. Water turbidity was measured with a turbidity tube (Myre and Shaw 2006), where water was collected and poured into the tube, before the turbidity was read on the scale. Turbidity was rated on a scale from 1 to 2 ; "1" represented water that was very clear and "2" water that was discolored or turbid. Substrate composition was determined in a $10 \times 10 \mathrm{~m}^{2}$ area. The substrate was collected and classified based on the Wentworth particle scale (Moyle and Senanayake 1984), using the following categories: (1) detritus, (2) mud, (3) silt, (4) sand, (5) gravel, (6) rubble, (7) boulder, and (8) bedrock. In a minority of instances, water and terrestrial vegetation were identified by genus or species, while the majority were 
identified by their family names, or common names in the case of the more ubiquitous species.

\subsection{Data Analyses}

R versions 2.14.1 (R Development Core Team 2011) and 2.15.2 (R Development Core Team 2012) were employed to analyze the water physicochemical parameters in order to determine the level of pollution in the water, abundance of Red Rainbowfish in each sampling group, and correlation between physicochemical parameters and Red Rainbowfish abundance and body size. Following water pollution determination, fish were arranged into three groups based on the level of pollution in their location. The Analysis Toolpak in Microsoft Excel 2007, and SPSS version 17.0 were used to calculate Red Rainbowfish body length for each group and the difference between groups, as well as the correlation between Red Rainbowfish abundance and introduced fish abundance, and Red Rainbowfish abundance and nitrate and nitrite concentration.

\subsubsection{Impact of Human Activities on the Red Rainbowfish}

Eight water parameters were used to determine the pollution levels in Lake Sentani, based on the samples taken from the predetermined zones. This analysis also established whether our zonation based on approximations of human impact was concurrent with the level of pollution in the zones' water.

In order to associate locations with water parameters, eight data variables in each location were reduced to a single variable, which was then used to differentiate each group. A dissimilarity matrix was created using the daisy algorithm (Kaufman and Rousseeuw 1990). Then, the partitioning around medoids (PAM) algorithm was used to identify the $k$-clusters of the data. The maximum average width of the resulting silhouette was used to identify the optimal number of clusters in the R file, which turned out to be 3 . In order to analyze the difference between clusters, the results were visualized using 
CLUSPLOT (Pison, Struyf, and Rousseeuw 1999). Then, means of each group of variables were produced to compare the difference between groups.

Analysis of variance (ANOVA) and Tukey's HSD test were conducted to assess groups' differences in water physicochemical parameters. Moreover, means of the parameters were produced for each group in each variable.

Human activities in each location were recorded, including the kind of activity in the lake and terrestrial area, as well as the kinds of houses in the area. Secondary data of the local populations were collected from Jayapura's Statistic Regency Office (BPS Kabupaten Jayapura 2010), as well as from districts and villages in the research locations.

\subsubsection{Red Rainbowfish Abundance}

Only samples from Lake Sentani, itself, were included In the Red Rainbowfish abundance analyses; thus, samples from Waena and Jembatan II Creeks were excluded. After Red Rainbowfish populations were counted, they were placed into three groups that corresponded with the level of pollution in their location. The Red Rainbowfish abundance in each group was then analyzed using a generalized linear mixed-effects model using AD Model Builder, which is able to count zero-inflated Poisson count data (Hilbe 2011). The differences in Red Rainbowfish abundance between groups were analyzed with Tukey's HSD test.

\subsubsection{Red Rainbowfish Abundance and Its Correlation with Physicochemical Parameters and Introduced Fish.}

To analyze whether there was a correlation between Red Rainbowfish abundance and water physicochemical parameters, a linear mixed-effect model was used. For logistical reasons, water parameters were measured a month after fish sampling. Determining the correlation between abundance and physicochemical parameters was based on the assumption that the water parameters did not change significantly between fish sampling and parameter analysis, and no change in human activities in any location during that period was observed. 
Pearson's correlation coefficient was used to analyze the correlation between Red Rainbowfish abundance and introduced fish abundance.

\subsubsection{Body Length of the Red Rainbowfish and Its Correlation with Water Physicochemical Parameters.}

Determining the correlation between Red Rainbowfish body length and water physicochemical parameters was based on the same assumptions as determining the correlation between abundance and water parameters.

One-way ANOVA was used to calculate the mean body length of each group, and Tukey's HSD test was performed to determine the difference in fish length between groups. Habitat quality, and especially water quality, is believed to impact fish body length. Therefore, a linear mixed-effect model was applied to analyze the correlation between fish body length and water physicochemical parameters.

\subsubsection{Sex Ratio of the Red Rainbowfish Between Groups}

The ratio of males to females of Red Rainbowfish was determined by dividing the number of males and females by the total number of fish in the same group, then multiplying the number by a hundred.

\subsubsection{Red Rainbowfish Habitat Characteristics}

The habitat characteristics of fish include water quality, substrate type, turbidity, water depth, and vegetation. These variables were assessed to identify the habitat preferences of the Red Rainbowfish. Substrate types and vegetation were qualitatively described, turbidity and water depth were measured visually, and water quality was analyzed with the PAM algorithm in R. 


\section{Results}

\subsection{Impact of Human Activities on Rainbowfish Habitats in Lake Sentani}

From the PAM-based analyses of the water physicochemical parameters (Kaufman and Rouseeuw 1990), the sampling sites were distinguished into three groups (Fig. 4.1). The test indicated two groups where heavy impacts were recorded (henceforth referred to as Group 1 and Group 2); and one with lower impact (Group 3). Group 1 included sampling sites located in Waena (AW) and Yoka (AY), Group 2 included sampling sites located in Yakonde (CY) and Jembatan II (AJ), while Group 3 included all the remaining sampling sites, which were located in Ayapo (BAy), Asei (BAs), Puai (BP), Rimiyebei (CR), and Kanale (CK) (Appendix 4).

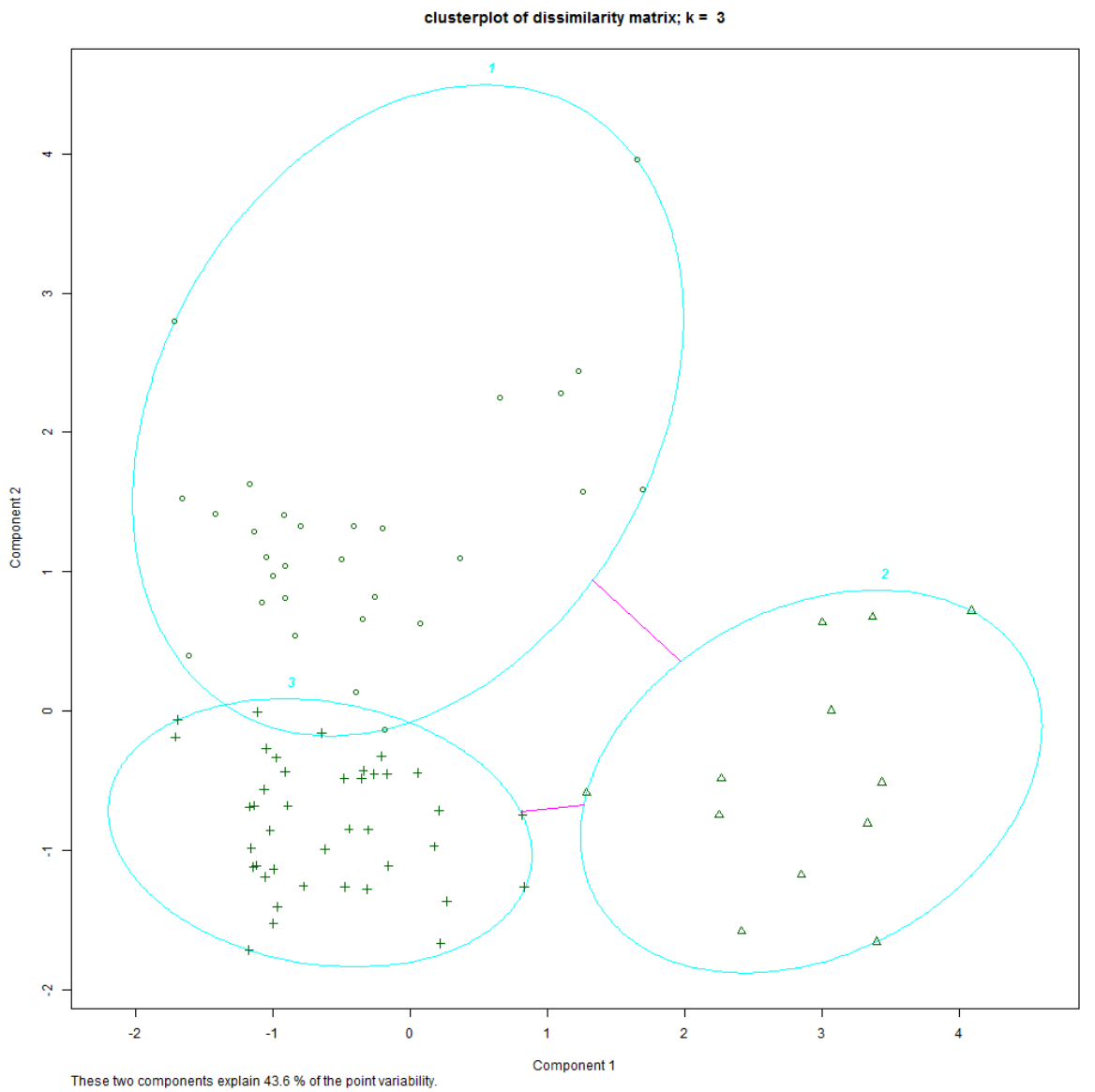

Fig. 4.1. Grouping of sampling sites based on water physicochemical parameters. 
Tukey's HSD test revealed that water physicochemical parameters between groups were significantly different (Table 4.1), in particular with regards to the Biological Oxygen Demand (BOD), Chemical Oxygen Demand (COD), phosphate $\left(\mathrm{PO}_{4}{ }^{3-}\right)$, nitrate $\left(\mathrm{NO}_{3}{ }^{-}\right)$, and nitrite $\left(\mathrm{NO}_{2}{ }^{-}\right)$. However, no significant differences in water temperature, water $\mathrm{pH}$ and Dissolved Oxygen (DO) were found. Group 1 had the highest level of $\mathrm{NO}_{3}{ }^{-}$and $\mathrm{NO}_{2}{ }^{-}$. Group 2 had the highest concentration of $\mathrm{BOD}, \mathrm{COD}$, and $\mathrm{PO}_{4}{ }^{3-}$. Meanwhile, Group 3 had low to medium levels of all the parameters. These results indicate that there were significant pollutants recorded in all sampling sites within Groups 1 and 2.

Table 4.1. Means of water physicochemical parameters in different groups. Standard deviations are given in parentheses.

\begin{tabular}{llll}
\hline $\begin{array}{l}\text { Water } \\
\text { Phsycochemical } \\
\text { Parameters }\end{array}$ & Group 1 & Group 2 & Group 3 \\
\hline Temperature $\left({ }^{\circ} \mathrm{C}\right)$ & $30.22(1.29)$ & $31.06(2.22)$ & $30.33(1.58)$ \\
$\mathrm{pH}$ & $7.25(0.10)$ & $7.14(0.17)$ & $7.06(0.10)$ \\
$\mathrm{DO}\left(\mathrm{mg} \mathrm{L}^{-1}\right)$ & $4.98(0.93)$ & $4.99(1.31)$ & $4.80(0.87)$ \\
$\mathrm{BOD}\left(\mathrm{mg} \mathrm{L}^{-1}\right)$ & $5,11(3.69)$ & $8.23(2.92)$ & $3.11(1.01)$ \\
$\mathrm{COD}\left(\mathrm{mg} \mathrm{L}^{-1}\right)$ & $24.29(10.26)$ & $83.60(15.65)$ & $23.29(9.68)$ \\
$\mathrm{NO}_{3}^{-}\left(\mathrm{mg} \mathrm{L}^{-1}\right)$ & $0.71(0.32)$ & $0.004(0.0009)$ & $0.18(0.22)$ \\
$\mathrm{NO}_{2}^{-}\left(\mathrm{mg} \mathrm{L}^{-1}\right)$ & $0.01(0.02)$ & $0.001(0.0004)$ & $0.002(0.0019)$ \\
$\mathrm{PO}_{4}{ }^{3-}\left(\mathrm{mg} \mathrm{L}^{-1}\right)$ & $0.41(0.32)$ & $0.88(0.30)$ & $0.30(0.26)$ \\
\hline
\end{tabular}

\subsection{Differences between Groups in Water Physicochemical Parameters}

The results of the Tukey HSD test show that most water physicochemical parameters differed between groups; those parameters were $\mathrm{PO}_{4}{ }^{3-}, \mathrm{NO}_{3}{ }^{-}, \mathrm{NO}_{2}{ }^{-}$, $\mathrm{BOD}$, and COD. Conversely, there were no differences in water temperature, $\mathrm{pH}$, and DO, which were recorded at levels that hovered around $30-31^{\circ} \mathrm{C}, 7 \mathrm{pH}$, and 5 DO $\mathrm{mg} \mathrm{L}^{-1}$, respectively (Fig. 4.2 to Fig. 4.4). 


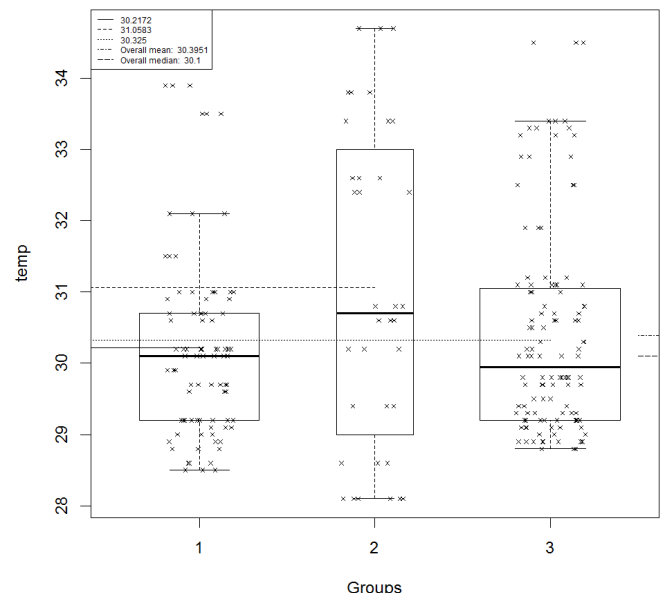

Fig. 4.2. Mean water temperature of the three groups.

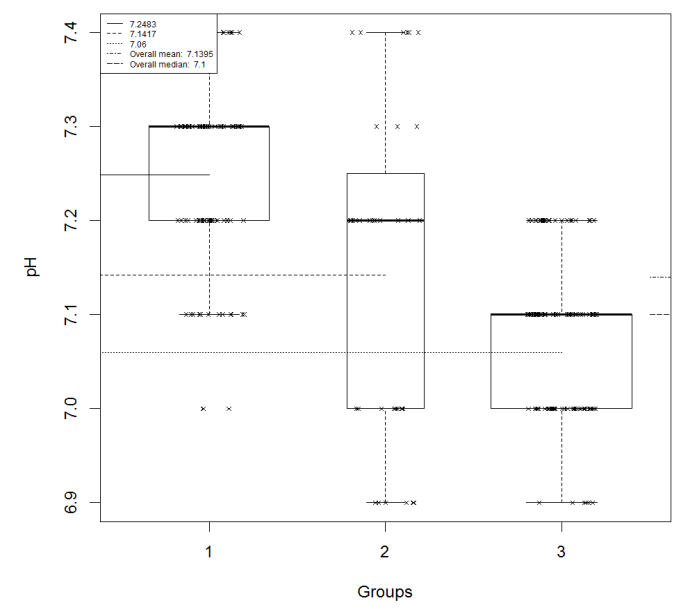

Fig. 4.3. Mean water $\mathrm{pH}$ of the three groups.

The highest levels of $\mathrm{NO}_{3}{ }^{-}$and $\mathrm{NO}_{2}{ }^{-}$were recorded in Group 1, where the means were $0.71 \mathrm{mg} \mathrm{L}^{-1}(s=0.32)$ and $0.01 \mathrm{mg} \mathrm{L}^{-1}(s=0,02)$, respectively. The lowest mean of $\mathrm{NO}_{3}{ }^{-}$, found in Group 2, was $0.004 \mathrm{mg} \mathrm{L}^{-1}$ ( $s=0.0009$ ), while Group 3's level was in between, with $0.18 \mathrm{mg} \mathrm{L}^{-1}(s=0.22)$. Furthermore, Groups 2 and 3's $\mathrm{NO}_{2}^{-}$means were similar, with $0.001(s=0.0004)$ and $0.002 \mathrm{mg} \mathrm{L}^{-1}(s=0.0019)$, respectively (Fig. 4.5 and Fig. 4.6).

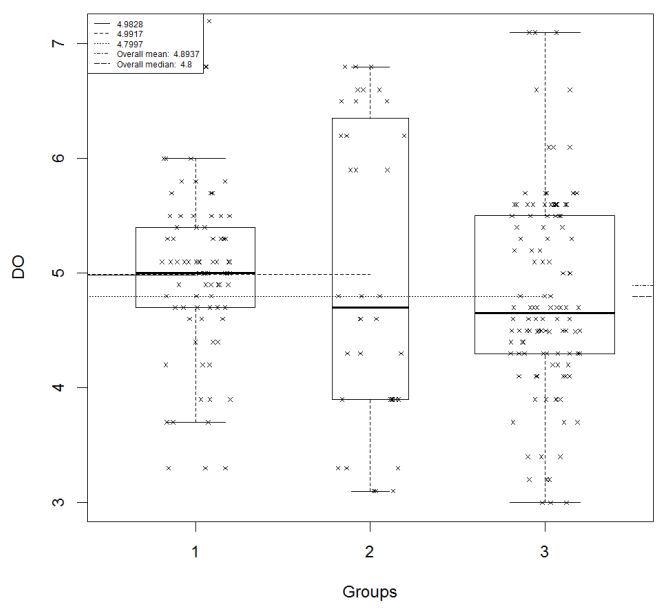

Fig. 4.4. Mean Dissolved Oxygen (DO) of the three groups.

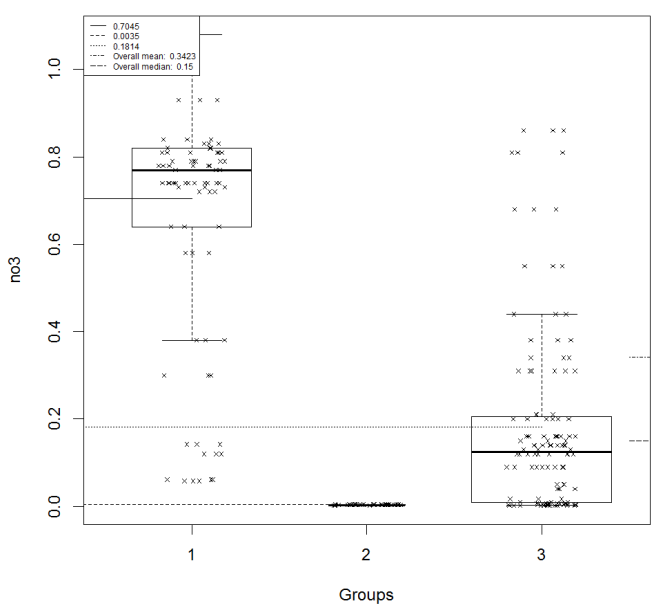

Fig. 4.5. Mean $\mathrm{NO}_{3}{ }^{-}$of the three groups. 


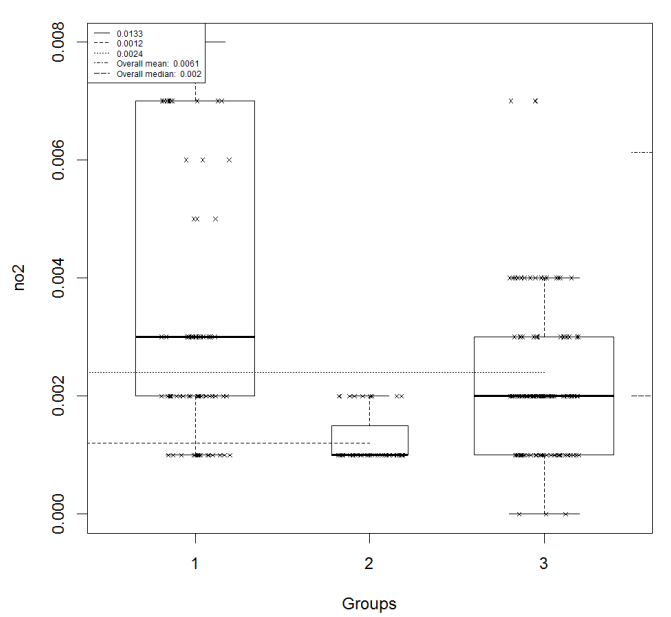

Fig. 4.6. Mean $\mathrm{NO}_{2}^{-}$of the three groups.

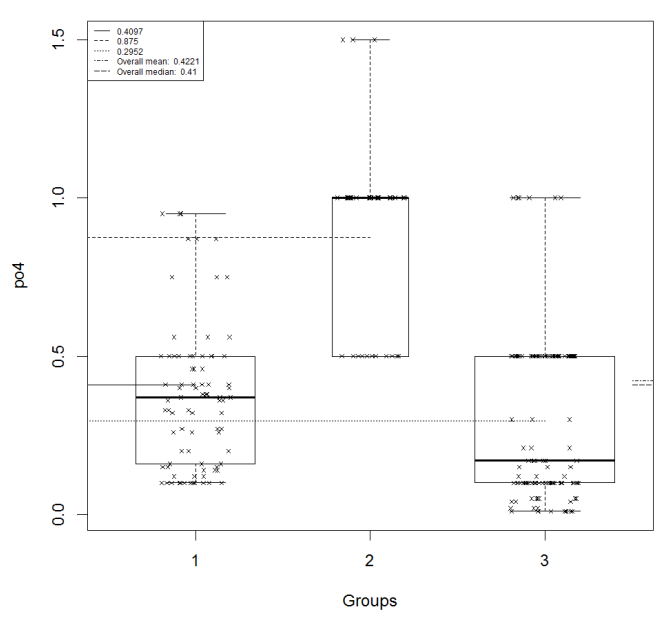

Fig. 4.7. Mean $\mathrm{PO}_{4}{ }^{3-}$ of the three groups.

Table 4.1 shows that the highest levels of $\mathrm{PO}_{4}{ }^{3-}, \mathrm{BOD}$, and $\mathrm{COD}$ were found in Group 2 (Fig. 4.7 to Fig. 4.9), while the lowest levels of these parameters were in Group 3. $\mathrm{PO}_{4}{ }^{3-}$ concentration in Group 2 was the highest of the three groups, with $0.88 \mathrm{mg} \mathrm{L}^{-1}(s=0.30)$, followed by Group 1 with $0.41 \mathrm{mg} \mathrm{L}^{-1}(s=0.32)$, and Group 3 with $0.30 \mathrm{mg} \mathrm{L}^{-1}(s=0.26)$. Group 2 also had the highest mean BOD with $8.23 \mathrm{mg} \mathrm{L}^{-1}(s=2.92)$, similarly followed by Groups 1 and 3 with $5.11 \mathrm{mg} \mathrm{L}^{-1}$ ( $s=$ 3.69) and $3.11 \mathrm{mg} \mathrm{L}^{-1}(s=1.01)$, respectively. Group 2 had a significantly higher mean of COD than the other groups, with $83.60 \mathrm{mg} \mathrm{L}^{-1}(s=15.65)$. In comparison, Group 1's mean was $24.29 \mathrm{mg} \mathrm{L}^{-1}(s=10.26)$, while Group 3's was $23.29 \mathrm{mg} \mathrm{L}^{-1}$ (s = 9.68).

In all water parameters, Group 3 was shown to have low to medium levels. Meanwhile, Group 1 had the highest levels of $\mathrm{NO}_{3}{ }^{-}$and $\mathrm{NO}_{2}{ }^{-}$, while Group 2 had the highest levels of $\mathrm{BOD}, \mathrm{COD}$, and $\mathrm{PO}_{4}{ }^{3-}$. 


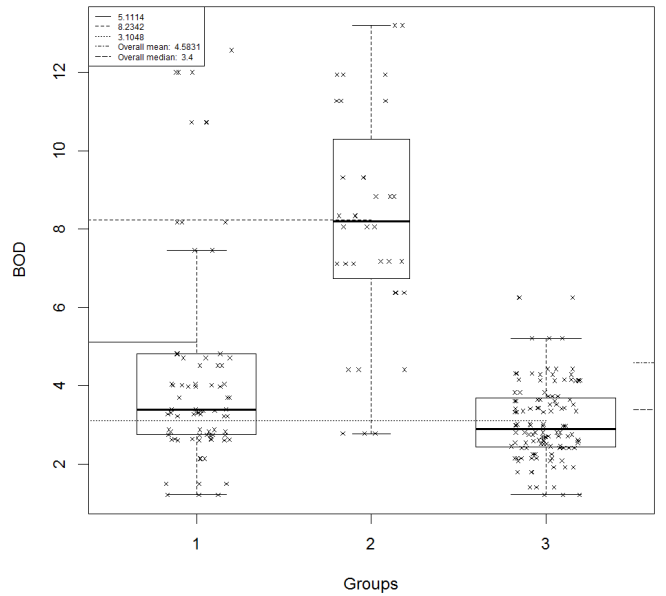

Fig. 4.8. Mean BOD of the three groups.

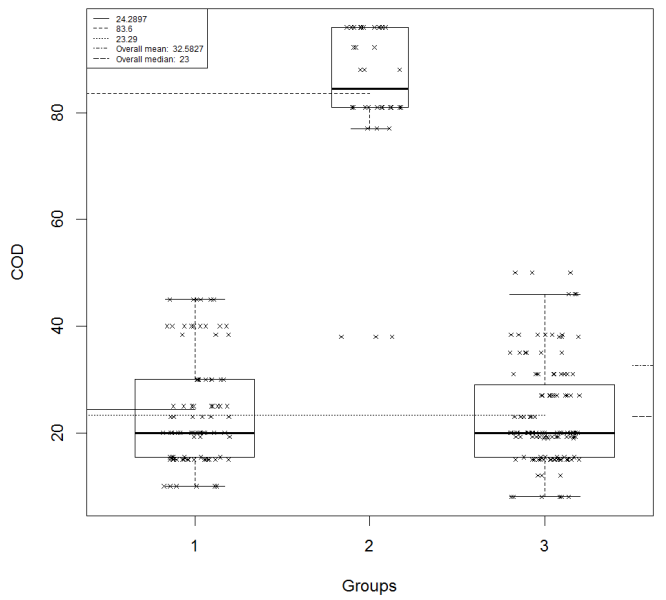

Fig. 4.9. Mean COD of the three groups.

\subsection{Impact of Pollutants on the Red Rainbowfish}

\subsubsection{Impact of Pollutants on Red Rainbowfish Abundance}

A generalized linear mixed-effect model using AD Model Builder was employed to examine rainbowfish abundance between groups (Hilbe 2011). No significant difference between the groups in Red Rainbowfish abundance was found (Table $4.2)$.

Table 4.2. Means of fish captured in each sampling site within group per sampling. Standard deviations are given in parentheses. $N=243$.

\begin{tabular}{rrrr}
\hline & Group 1 & Group 2 & Group 3 \\
\hline Mean & $22.71(21.65)$ & $25.29(34.64)$ & $23.69(28.07)$ \\
\hline
\end{tabular}

While the difference in overall abundance between groups was not significant, female Red Rainbowfish abundance showed significant differences between groups, with Group 1 and Group 2 having significantly higher abundances than Group 3 (Table 4.3).

Table 4.3. Female Red Rainbowfish abundance.

\begin{tabular}{lrrrr}
\hline & Estimate & Std. Error & $\mathrm{z}$ value & $\operatorname{Pr}(>|\mathrm{z}|)$ \\
\hline Group 1 & 0.414 & 0.174 & 2.38 & 0.0174 \\
Group 2 & 0.407 & 0.184 & 2.21 & 0.0273 \\
Group 3 & 0.038 & 0.148 & 0.26 & 0.7970 \\
\hline
\end{tabular}


Using a linear mixed-effect model to analyze Red Rainbowfish abundance and its correlation to water physicochemical parameters revealed that only nitrate influenced Red Rainbowfish abundance (Table 4.4). Nitrate concentration had a significant negative correlation with fish abundance $(p<0.05)$. Increased nitrate levels had an effect on decreasing fish abundance in Lake Sentani (Fig. 4.10).

Table 4.4. Correlation between Red Rainbowfish abundance and the water physicochemical parameter, Nitrate.

\begin{tabular}{rrrrrr}
\hline & Value & Std. error & DF & t-value & p-value \\
\hline Nitrate & -15.82 & 7.50 & 66 & $-1,947774$ & 0.039 \\
\hline
\end{tabular}

Fig. 4.10 also shows that nitrate had a very weak negative correlation with Red Rainbowfish abundance in Lake Sentani $(r=-0.231)$.

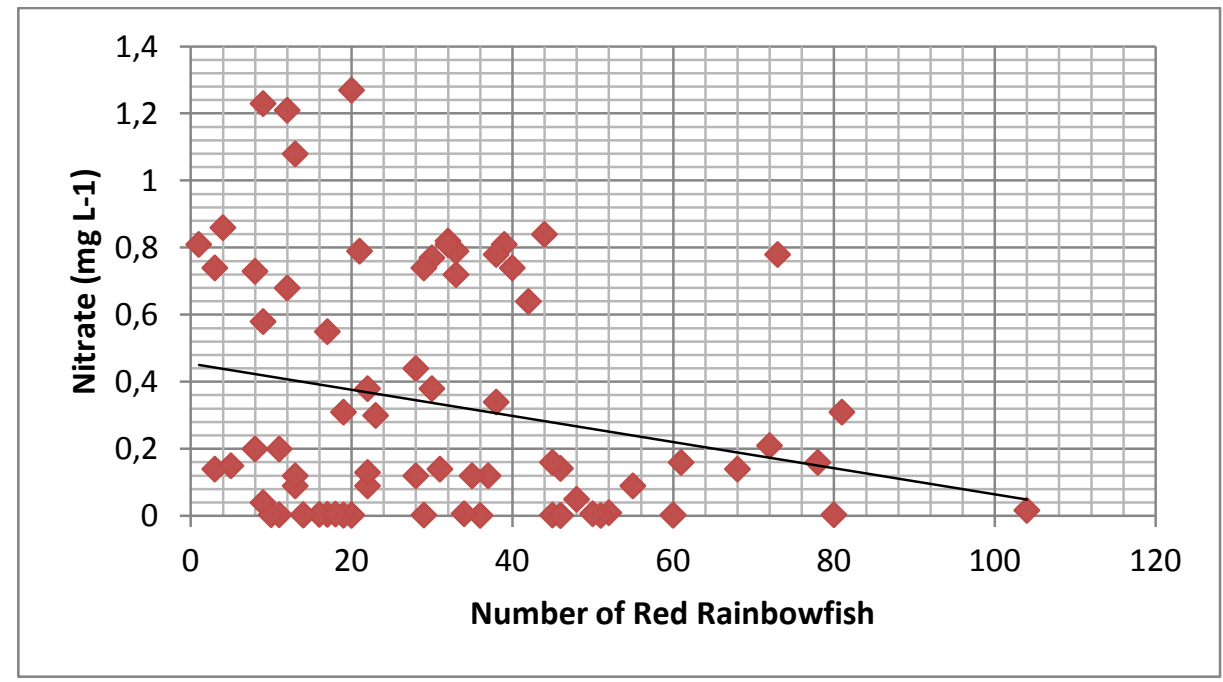

Fig. 4.10. Pearson's correlation coefficient of nitrate to Red Rainbowfish abundance in Lake Sentani.

\subsubsection{Impact of Pollutants on Red Rainbowfish Body Length}

Mean body lengths (SL) of the Red Rainbowfish were 65.52-70.72 mm. Table 4.5 shows the differences between Groups 1, 2, and 3 in terms of body length. Group 3 had the highest mean body length as well as the longest fish. Contrarily, Group 1 had the lowest mean body length, while its longest fish was the shortest of the three groups. Group 3 had the shortest fish. 
Table 4.5. Body length (mm SL) of the Red Rainbowfish. Standard deviations are given in parentheses.

\begin{tabular}{lrrr}
\hline & Group 1 & Group 2 & Group 3 \\
\hline Mean body length & $65.52(7.24)$ & $66.03(9.44)$ & $70.72(6.93)$ \\
Longest & 92.60 & 98.74 & 101.67 \\
Shortest & 40.40 & 26.19 & 25.01 \\
$\mathrm{~N}$ & 2017 & 2449 & 2768 \\
\hline
\end{tabular}

ANOVA revealed that the mean Red Rainbowfish body length was significantly different at $p<0.001$ between groups $[F(2,7231)=330.79, p<0.001)]$ (Table 4.5).

Based on Tukey's HSD test, Group 3's fish body length was significantly different from that of Group $1(x=5.20)$ and Group $2(x=4.70)$, each at $p<0.001$ (Table 4.6).

Table 4.6. Results of Tukey's HSD test on Red Rainbowfish body length.

\begin{tabular}{lcrrrr}
\hline Groups & $\begin{array}{c}\text { Mean Difference } \\
\text { between groups (mm) }\end{array}$ & $\begin{array}{c}\text { Std. } \\
\text { Error }\end{array}$ & Sig. & \multicolumn{2}{r}{ 95\% Confidence Interval } \\
\cline { 5 - 6 } & -0.50 & 0.24 & .091 & -1.06 & Lower Bound \\
\hline $1-2$ & $-5.20^{*}$ & 0.23 & .000 & -5.75 & -4.66 \\
$1-3$ & $-4.70^{*}$ & 0.22 & .000 & -5.22 & -4.19 \\
$2-3$ & & & & &
\end{tabular}

The linear mixed-effect model revealed that almost all the physicochemical parameters had no impact on Red Rainbowfish body length, except for phosphate. However, as is shown in Table 4.7, the impact of phosphate on Red Rainbowfish body length was not significant $(p=0.15)$.

Table 4.7. Correlation between phosphate and Red Rainbowfish body length.

\begin{tabular}{lrrrrr}
\hline Water Parameter & Value & Std. error & DF & t-value & p-value \\
\hline Phosphate & 1.87 & 1.28 & 66 & 1.46 & 0.15 \\
\hline
\end{tabular}




\subsection{Impact of Introduced Species on Red Rainbowfish Abundance}

Fig. 4.12 to Fig. 4.14 present the correlations between number of introduced species and Red Rainbowfish abundance in Lake Sentani. Fish found swimming alongside Red Rainbowfish included Tilapia (Oreochromis mossambicus), Hardlipped Barb (Osteochilus hasselti), Midas Cichlid (Amphilophus citrinellus), Red Breast Cichlid (A. longimanus), Striped Snakehead (Channa striata), Snakeskin Gourami (Trichogaster pectoralis), and Silver Barb (Puntius javanicus). Figure 4.11 shows the abundance of each species collected during three years' observations.

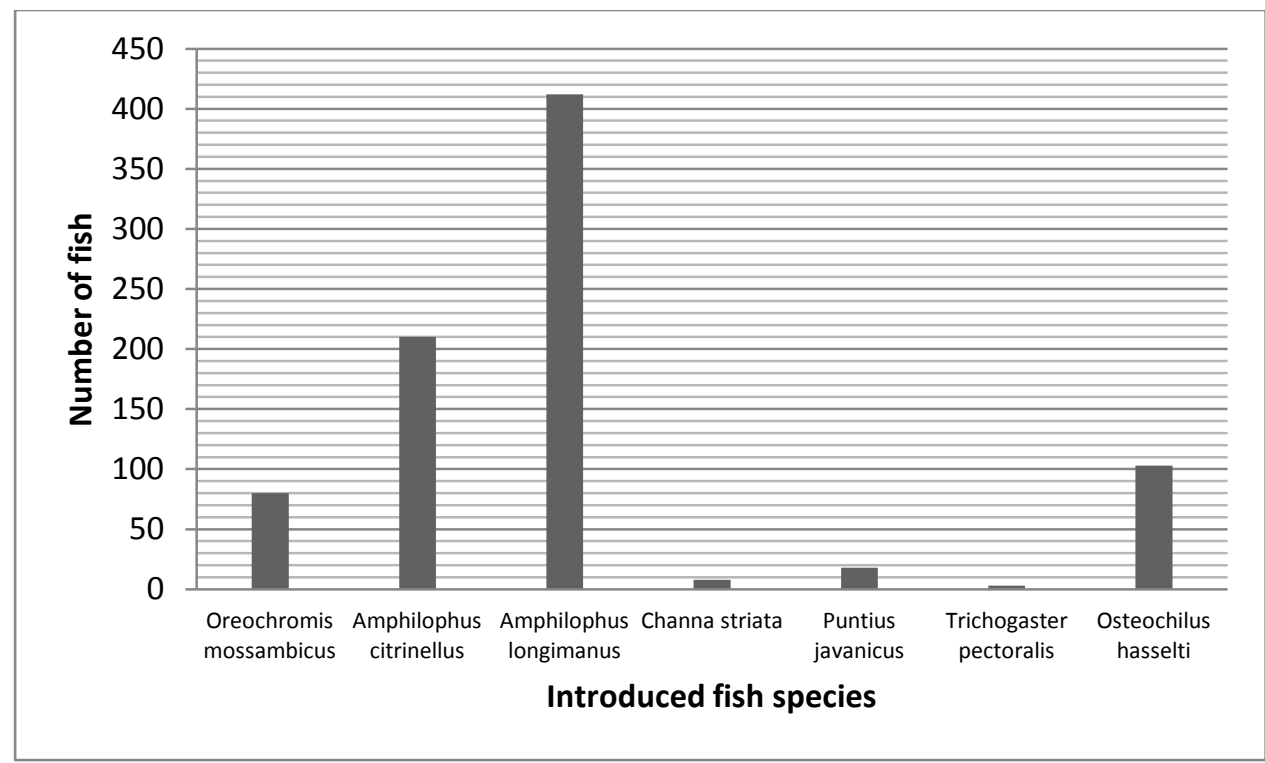

Fig. 4.11. Numbers of the seven introduced fishes collected in the same habitat of Red Rainbowfish. Pooled from all three years of sampling.

Pearson's correlation coefficient resulted in all three groups having a weak correlation between number of Red Rainbowfish and number of introduced fish. Group 1 and Group 3 had a weak positive correlation, $r=0.154$ and $r=0.285$, respectively, while Group $2(r=-0.068)$ had a weak negative correlation. These figures suggest that introduced fish species had a very low influence on the abundance of the Red Rainbowfish in Lake Sentani. 


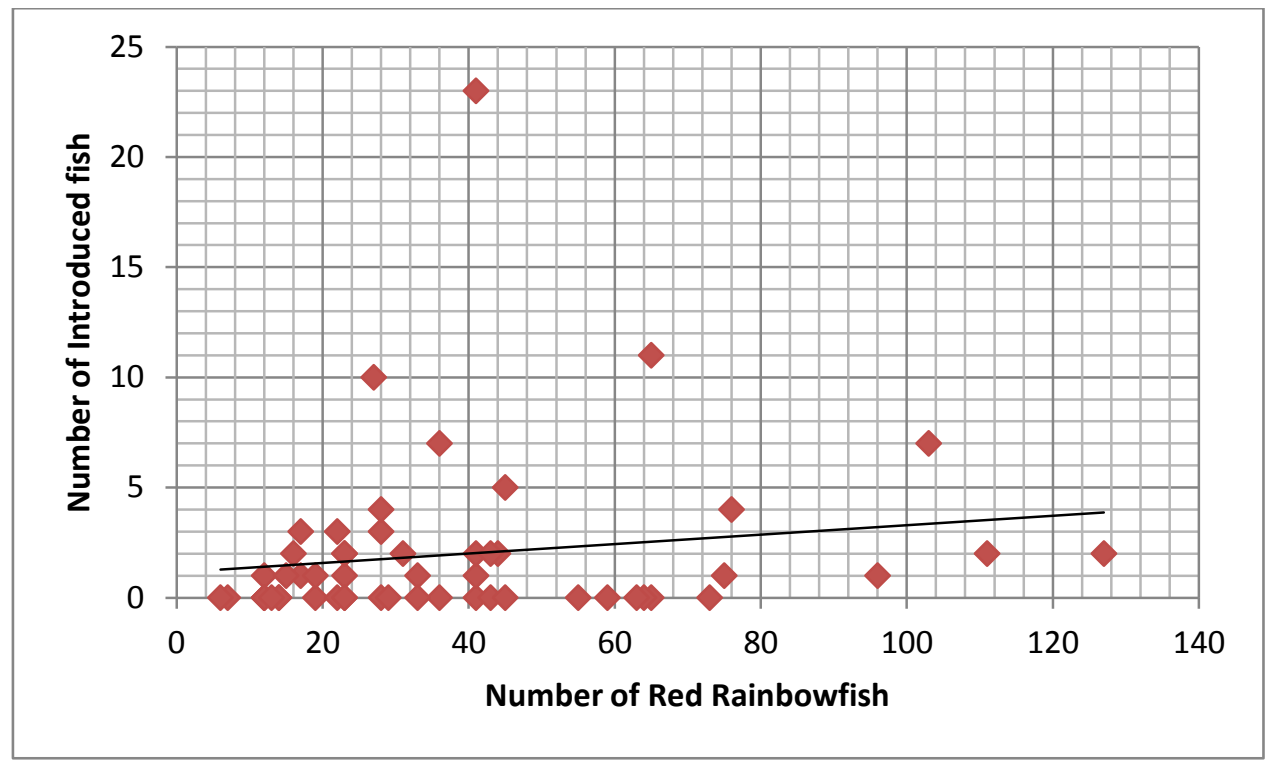

Fig. 4.12. Pearson's correlation coefficient of Red Rainbowfish abundance to introduced fish abundance in Group 1.

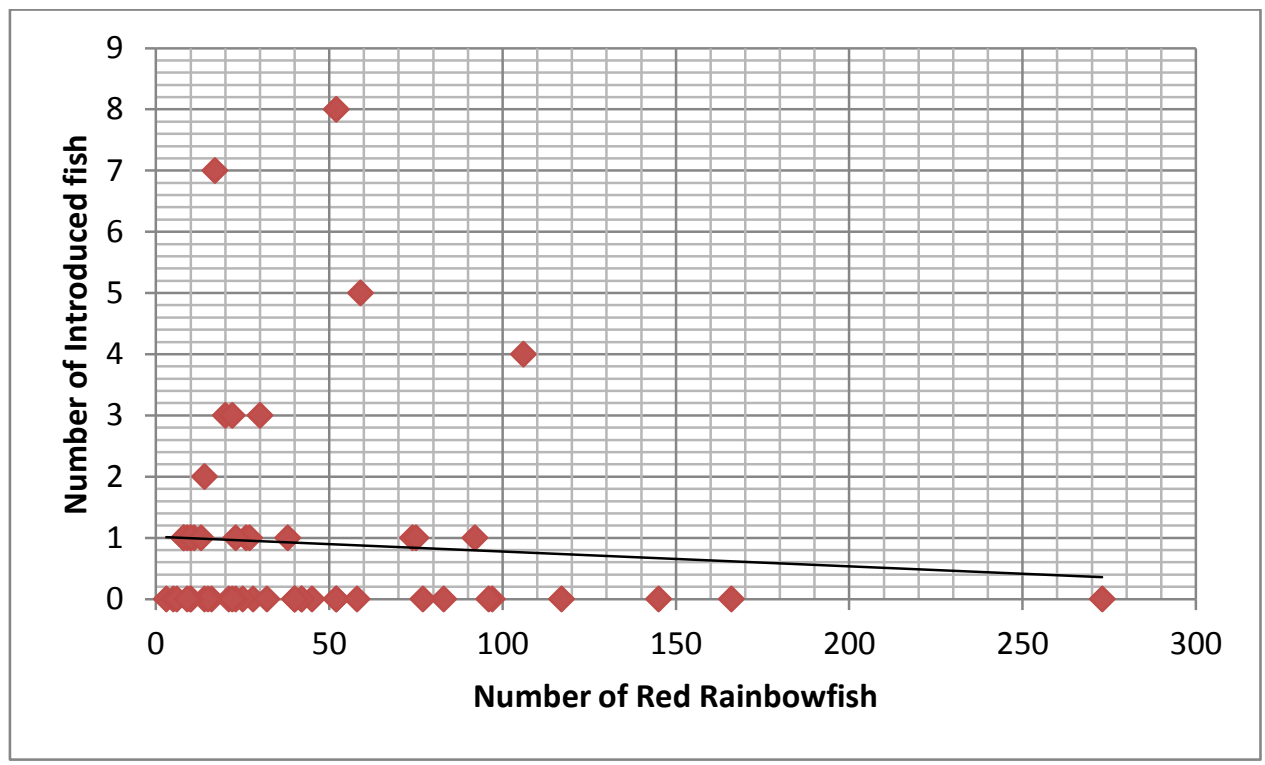

Fig. 4.13. Pearson's correlation coefficient of Red Rainbowfish abundance to introduced fish abundance in Group 2. 


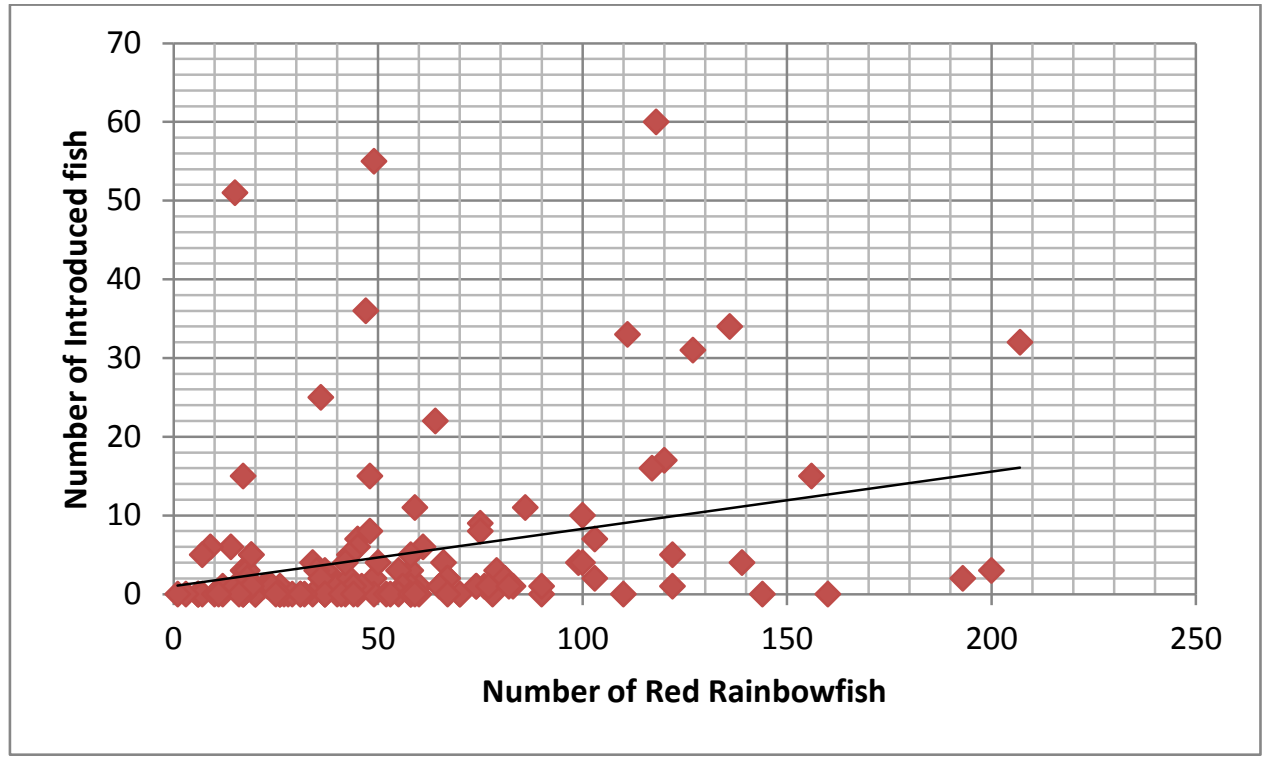

Fig. 4.14. Pearson's correlation coefficient of Red Rainbowfish abundance to introduced fish abundance in Group 3.

\subsection{Sex ratio of Red Rainbowfish}

Differences between the three groups in Red Rainbowfish sex ratio were examined to understand whether habitat quality (for instance, level of pollutants or number of introduced species) had an effect on sex ratio (Table 4.7).

Table 4.8. Sex ratio of the Red Rainbowfish.

\begin{tabular}{lrrr}
\hline Group & Male & Female & Ratio \\
\hline Group 1 & 1795 & 294 & $6.14: 1$ \\
Group 2 & 1760 & 306 & $5.67: 1$ \\
Group 3 & 6656 & 806 & $8.10: 1$ \\
\hline
\end{tabular}

Table 4.7 shows that sex ratios between Group 1 and Group 2 were similar, while Group 3 had the highest sex ratio. In a previous study in Lake Sentani, Siby (2009) found that the Red Rainbowfish had a sex ratio of 1:1 in the months of December, April, and May, and 1:2.5 or 1:3 in the months of January and February. Her results were similar to those of Red Rainbowfish found in captivity, which is $1: 1$, although different from ratios of other rainbowfish species, such as the Lake Tebera Rainbowfish (Melanotaenia herbertaxelrodi), which could have 
$100 \%$ males or females, depending on water temperature (Johannes Graf, pers. comm.). Higher water temperature resulted in more males, while lower water temperature produced more females.

\subsection{Substrate types}

Mostly, the fish were distributed along the shallow parts of Lake Sentani's shoreline. The fish were observed in all habitat types along the shoreline or up to $100 \mathrm{~m}$ from creek mouths, including mud, silt, sand, gravel, cobble, and boulder. The fish, however, are known to prefer sand, gravel, cobble, and boulder more than mud or silt. The highest fish abundance was found in gravel and cobble, while fish found in mud and silt were more rare (Fig. 4.15, Fig. 4.16). The substrate types in each sampling site can be seen in Appendix 5.

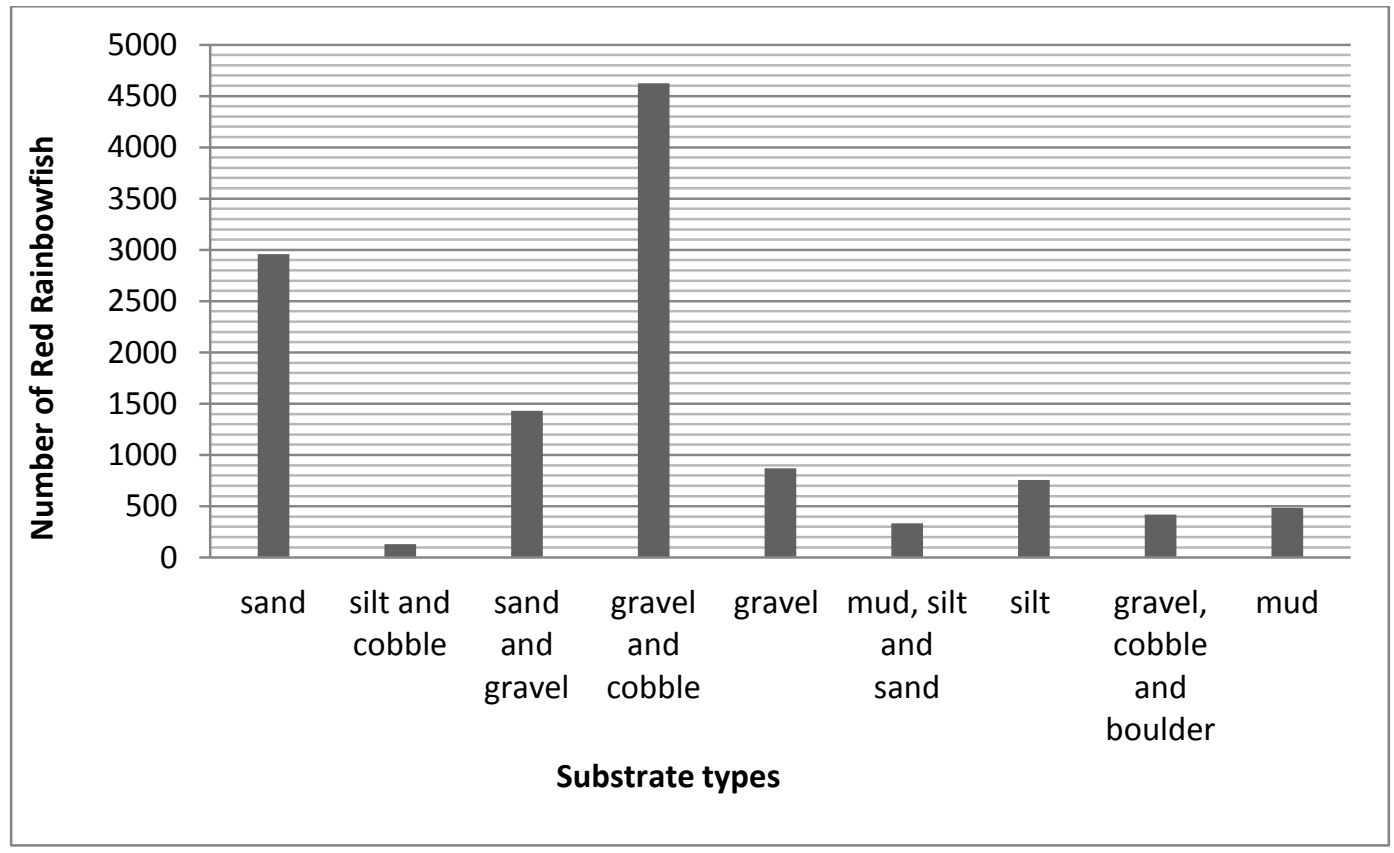

Fig. 4.15. Red Rainbowfish abundance in different substrate types. Pooled from all three years of sampling. 


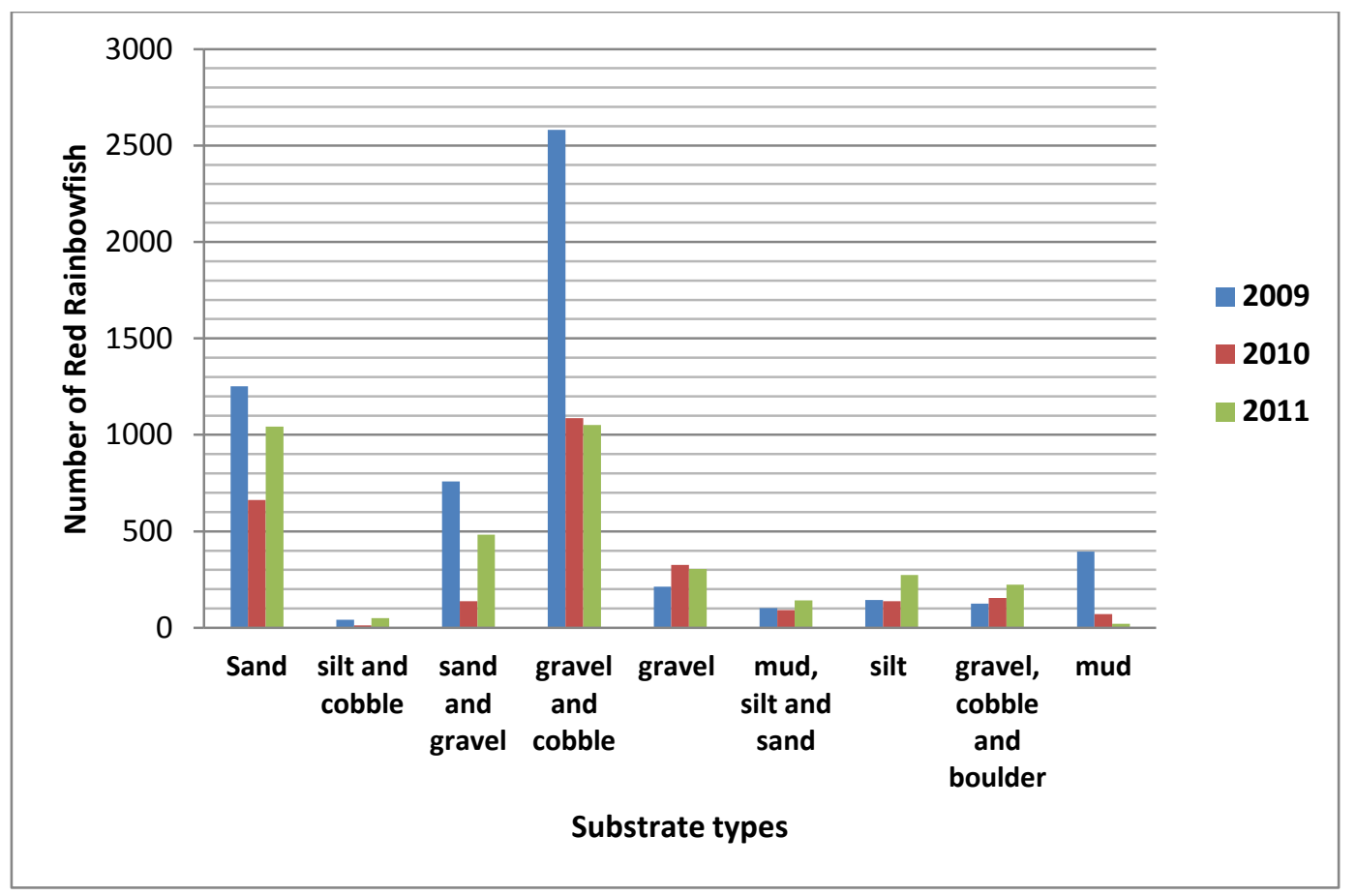

Fig. 4.16. Red Rainbowfish abundance in different substrate types, from 2009-2011.

\subsection{Vegetation}

Red Rainbowfish are known to prefer habitats with submerged plants, roots, and wood debris, which are all commonly found along shorelines. In Lake Sentani, various types of terrestrial vegetation were also found along the shoreline. The vegetation grows naturally, or is planted by people who reside in the area. Generally, the fish were abundant amongst the roots of some plants, such as Sago Palm, or large trees, such as Ficus spp., as well as grasses. Large trees also provided shade for the fish. Hydrilla verticillata was the most ubiquitous water plant, being found in every location of Groups 1 and 2. Vallisneria americana was observed in one sampling site of a location in Group 1 (AY). One type of Water Lily (Nymphaeaceae) was found in one site in AJ (Group 2), and Water Hyacinths (Eichhornia crassipes) were found in four locations, namely AW (Group 1), BAy, BAs, and BP (Group 3). No Hydrilla verticillata in BAy, BAs, BP, CR, and CK were found (Appendix 5). Water and terrestrial plants, and their relation to Red 
Rainbowfish abundance in the different sampling locations, is shown in Fig. 4.17. Terrestrial plants, which serve as a food source for insects that are eaten by the fish, were more common than water plants, in terms of both number and range of families, which included Arecaceae, Moraceae, Sapindaceae, Fabaceae, Combretaceae, and Bambusaceae. There were also some families of herbs and grasses, the latter of which provided a playing ground, nursery ground, and food source for the fish.

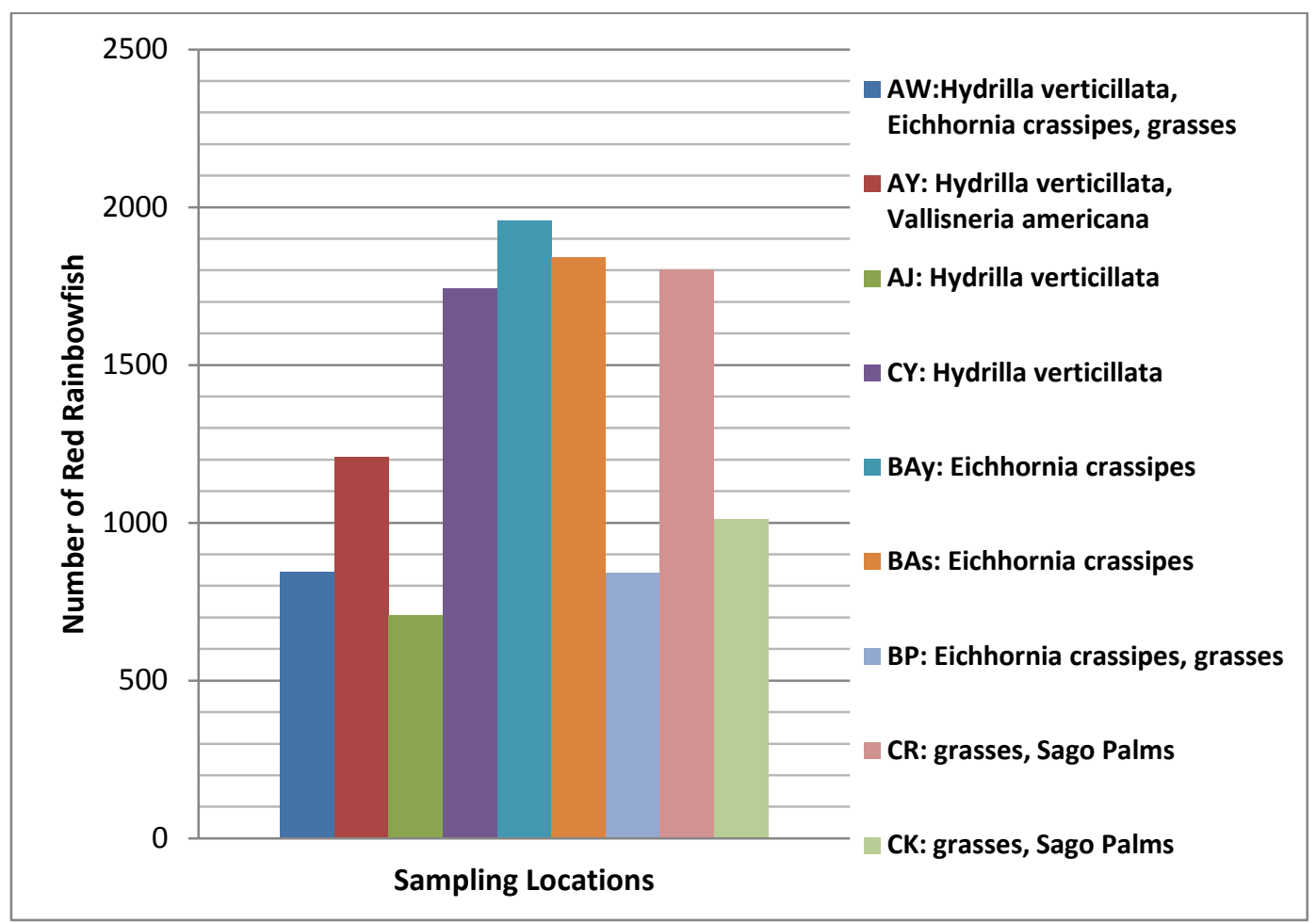

Fig. 4.17. Red Rainbowfish abundance and its relation to the water and terrestrial plants in each location. Pooled from all three years of sampling.

\subsection{Water depth}

The highest Red Rainbowfish abundance was found at water depths of $0-60 \mathrm{~cm}$ and in the early morning, 06.00-09.00 am, and afternoon, around 16.00-18.00 pm. Some fish were also detected at around a depth of two meters, as well as some at depths exceeding two meters. Local spearfishermen reported seeing Red Rainbowfish in even deeper water, while seine fishermen were observed catching them. However, the low number of individuals found in both cases 
suggests that although they can be found in such deep water, the occurrence is rare.

The Red Rainbowfish usually avoided high light intensities. Therefore, fish were rarely found in shallow waters during periods of high light intensity, such as from late-morning to mid-afternoon, having dived to deeper waters and shoaled near food sources. In cases where they remained near the surface, they had moved to shadowed areas, such as under stilt houses or submerged plants.

Water turbidity along the shoreline was very low. However, habitat degradation was observed in some locations, particularly in inlets, increasing water turbidity. Water turbidity in most of the sampling sites along the shoreline of the lake was measured to be 5 NTU. This was determined as level 1 , where the water was very clear and fish sampling was conducted without any difficulty. The two exceptions were sites in the mouths of AJ Creek (Group 2) and AW Creek (Group 1). AJ Creek had a turbidity of 240 NTU and AW Creek had a turbidity of 14 NTU. These two sites were determined as level 2, where fish were difficult to find. A compiled list of all relevant ecological parameters measured at each sampling site is given in Appendix 5. 


\section{Discussion}

\subsection{Sampling methods}

When dealing with rapid ecosystem degradation and habitat loss, conservationists or natural scientists have to deal with difficulties in finding sampling methods that can provide "quick data sets" to answer problems. These problems intensify in studies taking place in the field and especially when study sites are not immune to human interaction. These were conditions in the case of this study. Along with the very nature of the study, few similar studies have been conducted and widely published, and many of those that have were conducted by undergraduate students. Another disadvantage is the lack of periodic data on the lake's water conditions from local environmental agencies, and thus any intention to study the habitat changes (or degradation) in Lake Sentani is limited to being based solely on the few available studies with various sampling methods. Many studies on the rainbowfishes have focused more on the fish themselves than their habitats.

This study was designed with the assumption that the parts of Lake Sentani near less populated areas can serve as baseline data for its water as well as the Red Rainbowfish. Presumably, areas with lower human populations have fewer human activities, and thus will be less polluted than heavily-populated areas. This idea can be applied to other aquatic ecosystems in Papua, of which data and sources of ecological research on certain species are limited.

Conducting research, such as that on species ecology or inventorying of species diversity, in Papua is a costly endeavor, particularly if a long study period and large sample size are required, or funds for transportation, labor, food, accommodation, and other needs in locations that are almost always remote or isolated. Additionally, limited research on biodiversity conservation, along with limited research tools and facilities, also contribute to the need for high financial support. For instance, there is to our knowledge only one good environmental laboratory in Papua, located in Jayapura and belonging to the Health Department 
of the government of Papua Province. This laboratory is central to water research in Papua, as it is used for most of the water quality analysis taking place in the province. Another continuing hindrance is apprehension amongst local tribes to outsiders; permission to conduct research in remote areas is often granted only after a lengthy period of acquaintance with the tribes, which can last as long as a week. Nevertheless, despite the lack of present research on Papua's biodiversity, the number of studies has increased steadily since the 1980s, and the trend is that this will continue.

\subsubsection{Zonation of Sampling Sites}

No data on Lake Sentani's water quality were available from the local government, and although there has been some research on it, the results have not been reliable. Moreover, the studies in question were not carried out in the same locations as those in this survey. For this reason, lake zonation in our study was based on population number.

Location regroupings were based on water quality, which is a more accurate indicator than population number and household type. In addition, human activities are probably a better determinant of different water qualities than population density, as different activities have different effects on water quality. Future research to differentiate the locations in Lake Sentani where water quality data is lacking and levels of water quality are presumably different (based on observations of the level of human activity) should be based on the kind of human activity taking place (for example subsistence or modern agriculture, manufacturing or other industrial activities, and logging), in addition to the number of people. Nevertheless, analysis of water physicochemical data remains the best pollution identification tool. 


\subsubsection{Water sampling}

Because of logistical constraints during field sampling, water parameters were not sampled at the same time as Red Rainbowfish. If possible, water samples should be measured at the same time as fish sampling. Moreover, to record the variability of water quality and its impact on the Red Rainbowfish, we recommend that water quality measurement take place in both dry and rainy seasons, which is optimally July-August (dry season) and November-January (rainy season).

\subsubsection{Fish sampling}

Active gear, specifically a beach seine, which is typically used in freshwater fish sampling in very shallow waters (Portt et al. 2006), and always used in rainbowfish sampling, was used for fish sampling during the survey. The seine net was held by two people, one on each end, who walked in parallel through the water with the seine forming a U-shape behind them (Portt et al. 2006, Sutherland 1996). Fish were driven into the net by four people. The number of people will depend on net length and drag, where is hauling usually done by at least two people (Sutherland 1996). This method was effective for counting the relative abundance of the Red Rainbowfish. However, one factor specific to the Red Rainbowfish should be considered when using this gear and sampling procedure, namely its high sensitivity to any disturbance in the water, as the fish will swim away from disturbances in or near the water. To overcome this problem, fish sampling should be postponed for at least 15 minutes until Red Rainbowfish return to the area, while care is taken to cause no further disturbances in the area. In the meantime, net holders and fish drivers could stay in or out of the water. Those holding the net should enter the water first from an area adjacent to the sampling site, heading toward the shore. Then, while moving slowly to the sampling site, the fish-drivers may move in the direction of the net. Two net-holders and four fish-drivers were suitable for covering the catchment area of the 3.6 meter long net. However, three net-holders would be 
more ideal, with two people holding each end of the net and one holding the middle part of the lead line. Using only two net-holders may result in inadequate control of the lead line, resulting in it lifting up from the lake floor. A third person would thus be able to prevent fish from escaping by holding the lead line on the lake floor while moving with the other two holders. The net should be hauled in medium speed (Sutherland 1996). Additionally, more (five people) fish-drivers covering the area would also improve sampling, with more people being able to compensate for longer nets.

Fish sampling was conducted in very shallow water along the shoreline, less than 1.5 meters, as it is the preferred depth of the Red Rainbowfish. The assumption was that males and females would be found in the same ratio along the shoreline. However, males were far more abundant than females. Overall abundance of female Red Rainbowfish was very low in all locations. Siby (2009) found that female Red Rainbowfish prefer deeper water, shoaling amongst water plants. Using four different mesh sizes of gill nets placed in the lake's deeper waters, she found a male/female ratio of 1:1. Therefore, the different habitat preferences between males and females are the likely cause of the different sex ratios. As a consequence, different sampling sites should be used to cover male and female Red Rainbowfish. Moreover, different fish sampling gear should be considered for sampling in different habitats. A beach seine cannot be used in deeper waters. Siby (2009) did experiment with five different gill net mesh sizes -0.5 inches $(1.27 \mathrm{~cm}), 1$ inch $(2.54 \mathrm{~cm}), 1.25$ inches $(3.175 \mathrm{~cm}), 1.5$ inches $(3.8 \mathrm{~cm})$, and 2 inches $(5.08 \mathrm{~cm})$-sampled male and female Red Rainbowfish in deeper water in Lake Sentani. Therefore, a combination of active and passive gears should be used in male and female Red Rainbowfish sampling; these would include a beach seine with a mesh size of $\leq 0.5 \mathrm{~cm}$, hoop, fyke and trap nets, gee or minnow traps (Portt et al. 2006; Hill et al. 2005; Sutherland 1996), pot traps, and purse seine (Sutherland 1996). Fish sampling using a gill net will kill the Red Rainbowfish, and therefore is not recommended for Red Rainbowfish sampling. 
Future Red Rainbowfish sampling using a seine net should employ our aforementioned method, while sampling using the passive gears should take place at incremental depths: 2, 3, 4, 5, and 6 meters toward the lake's center. These different gears and depths could more effectively cover male and female abundance of the Red Rainbowfish in Lake Sentani. Moreover, for monitoring purposes, we suggest that future research be located in the same parts of Lake Sentani, thus enabling a more comprehensive understanding of the lake's water quality and the status of the Red Rainbowfish.

\subsection{Impacts of Human Activities on Red Rainbowfish Habitats in Lake Sentani}

This study revealed that the habitats of the Red Rainbowfish in Lake Sentani have been degraded by increasing nitrate $\left(\mathrm{NO}_{3}{ }^{-}\right)$, nitrite $\left(\mathrm{NO}_{2}{ }^{-}\right)$, and phosphate $\left(\mathrm{PO}_{4}{ }^{3-}\right)$ levels. This was the case in all sampling sites, and especially so in areas with high human population densities (Groups 1 and 2).

During the study design, the lake was categorized into three different zones (study sites) based on human population density, with the assumption that higher population density will have higher human impact. Statistical analyses of water parameters revealed similar zoning. Only a small number of sampling sites did not match the predetermined zones. The analyses also revealed that, along with population density, different human activities affected the habitats differently. Based on the water parameter analyses, all the sampling sites were newly categorized into three groups. Two groups (Groups 1 and 2) had high levels of pollutants, while the third group (Group 3 ) had only a low level of detected pollutants.

The highest levels of nitrate and nitrite were found in the most populated areas, such as AW and AY Villages in Group 1 (Table 4.1). These locations were found in the heavily-populated districts in the eastern part of the lake. Communities in these areas produced both organic waste, including discarded food, oil, dead animals and plants, and human, pet, and livestock feces, and 
inorganic waste, including detergent and litter. All these wastes were dumped untreated into the lake, which is a major problem in many other parts of the world, as well (Søndergaard and Jeppesen 2007). In this area, there were smallscale tofu factories, restaurants, and carwash facilities, all of which discharged their waste directly into creeks, which then washed it into the lake during the rainy season.

Notably, AJ and CY (Group 2), with their lower population densities compared with AW and AY Villages (Group 1), had high levels of $\mathrm{PO}_{4}{ }^{3-}, \mathrm{BOD}$ (Biological Oxygen Demand), and COD (Chemical Oxygen Demand) (Table 4.1). Many residents in these villages worked as fishermen, and factories or other more pollutive facilities were nonexistent. Thus, the high level of phosphate in the water, which tripled the BOD and COD levels in these locations, was likely the result of residents' use of the lake, which was mainly for bathing, washing, or eliminating waste. AJ is located along a major provincial road that intersects the village's creek. As a result of the heavy traffic passing the village and creek, a great number of non-residents use the creek to wash their clothing or vehicles, releasing large amounts of detergent into the creek, and hence Lake Sentani. CY is located close to a major road serving Sentani Regency's more remote districts, and human activity was very limited, except by local residents, who would establish caged fish farms and use pelleted feed that causes sedimentation, as well as raise pigs and cows. Fish pellets are one of the main sources of nutrients to the aquatic ecosystems in which they are used (Troell and Berg 1997), and may have contributed to the increased phosphate and nitrogen (nitrate, nitrite, and ammonia) in Lake Sentani.

Group 3 consists of a zone with traditional villages, mostly occupied by a local tribe (Sentani). Generally, they live in traditional stilt houses, using Lake Sentani for fishing, washing, bathing, and elimination, and its water for cooking. They also produced small amounts of litter; lower than both Group 1 and Group 2. Although these areas had better water quality than those in Groups 1 and 2, some pollutants were recorded at levels that violated the Indonesian 
government's water quality regulations (Sekretaris Negara Republik Indonesia 2001). For instance, at CR and CK Villages, which had populations of less than 10 people, phosphate was recorded at $0.3 \mathrm{PO}_{4}{ }^{3-} \mathrm{mg} \mathrm{L}^{-1}$, above the limit of $0.2 \mathrm{PO}_{4}{ }^{3-}$ $\mathrm{mg} \mathrm{L}^{-1}$ for humans and fisheries.

This study revealed that the habitats of Lake Sentani face serious threats from the pollution caused by human activities around the lake. Water parameter analyses showed that decomposition of organic matter by microorganisms led to increased concentrations of $\mathrm{NO}_{3}^{-}\left(0.0035-0.70 \mathrm{mg} \mathrm{L}^{-1}\right), \mathrm{NO}_{2}^{-}\left(0.0013-0.01 \mathrm{mg} \mathrm{L}^{-1}\right)$, $\mathrm{PO}_{4}{ }^{3-}\left(0.30-0.88 \mathrm{mg} \mathrm{L}^{-1}\right)$, BOD (3.10-8.23 $\left.\mathrm{mg} \mathrm{L}^{-1}\right)$, and COD (23.29-83.60 $\left.\mathrm{mg} \mathrm{L}^{-1}\right)$, and expectedly, decreased DO (4.80-4.99 $\left.\mathrm{mg} \mathrm{L}^{-1}\right)$. These levels indicate that Lake Sentani received a large amount of biodegradable organic matter (Gray 1989; Hellawell 1986).

Decreasing habitat or water quality may negatively influence fish diversity and distribution (Tawari-Fufeyin and Ekaye 2007), and in turn cause biodiversity loss (Søndergaard and Jeppesen 2007; Orrego et al. 2009). Moreover, human disturbances in stream and lake ecosystems impact fish assemblage structure (Vila-Geispert et al. 2002), distribution and diversity (Tawari-Fufeyin and Ekaye 2007; Kouamélan et al. 2003), and habitat quality and fish community patterns (Orrego et al. 2009).

\subsection{Water quality changes in Lake Sentani}

This study showed that concentrations of BOD, COD, and phosphate in Lake Sentani exceeded the government's limits. The pollutants mostly originated from untreated organic and inorganic wastes from households surrounding the lake, as well from small-scale farming. The increased phosphate was likely the result of the large amounts of detergent and animal and human feces being deposited into the lake. Another nutrient source was the prevalence of caged fish farms, some of which were found along the shoreline and in the lake's islands.

A previous study in eleven different locations of Lake Sentani found that the total nitrogen (nitrate, nitrite, and ammonia) was within acceptable limits, 
0.5-1.5 mg TN L ${ }^{-1}$ (the standard is $10 \mathrm{mg} \mathrm{TN} \mathrm{L}^{-1}$ ), whereas phosphate was very high, 0.5-3.8 mg PO${ }_{4}{ }^{3-} \mathrm{L}^{-1}$ in November 2005 (Bapedalda Kabupaten Jayapura 2005). BPSDALH Provinsi Papua (2009) similarly recorded phosphate levels in very high concentrations and nitrate and nitrite levels again within acceptable limits in six different locations in August-December, 2009. And exception was nitrate in $\mathrm{BP}$, which reached the maximum standard, $10 \mathrm{mg} \mathrm{NO}{ }_{3}^{-} \cdot \mathrm{L}^{-1}$, in December, 2009. Phosphate levels were 0.2-4.95 $\mathrm{mg} \mathrm{PO}_{4}{ }^{3-} \mathrm{L}^{-1}$, nitrate levels were 0.045-10 $\mathrm{mg} \mathrm{NO}_{3} \mathrm{~L}^{-1}$, and nitrite levels were 0.001-0.095 $\mathrm{mg} \mathrm{NO}_{2}{ }^{-} \mathrm{L}^{-1}$. Both studies indicated that the lake had been polluted, most likely by sewage.

A previous study by BPSDALH Provinsi Papua (2009) found an uncertain pattern of water quality change between seasons in Lake Sentani. The dry season had a high level of pollutants, because of the decreasing water level, while the rainy season had better water quality, after the water level rose again. Nevertheless, the rainy season is not always beneficial to lake ecosystems. Rain transfers pollutants from the terrestrial environment to the lake, increasing the level of pollutants such as phosphate, nitrate, and nitrite. For instance, the institution found certain pollutants to have lower levels in the rainy season than in the dry season, whereas other pollutants were lower in the dry season than in the rainy season. Nitrite and nitrate levels in AJ, BP, and Bay are two examples. Nitrite levels decreased or stay steady between the dry month (August) and wet month (December) in those three locations, 0.018 and $0.003 \mathrm{mg} \mathrm{NO}_{2}{ }^{-} \mathrm{L}^{-1}, 0.014$ and 0.06 $\mathrm{mg} \mathrm{NO}_{2}{ }^{-} \mathrm{L}^{-1}$, and 0.017 and $0.018 \mathrm{mg} \mathrm{NO}_{2}{ }^{-} \mathrm{L}^{-1}$, respectively. Nitrate levels were higher in the dry season and lower in the rainy season in AJ and Bay, 1.4 and 0.6 $\mathrm{mg} \mathrm{NO}_{3}{ }^{-} \mathrm{L}^{-1}$, and 2.7 and $0.2 \mathrm{mg} \mathrm{NO}_{3}{ }^{-} \mathrm{L}^{-1}$, respectively; while they were lower in the dry season but increased in the rainy season in $\mathrm{BP}, 2.3$ and $10 \mathrm{mg} \mathrm{NO}_{3}{ }^{-} \mathrm{L}^{-1}$. These data indicate that pollutants in Lake Sentani could increase, decrease, or show no significant change between dry and rainy seasons, and results will vary depending on water sampling time (morning, noon, or afternoon), location, lake column measured (surface, middle, or bottom of the lake), and which part of the 
lake is measured (littoral or pelagic zone), along with season. Therefore, these data were not comparable to our own data in showing whether the lake's water quality has trended positively or negatively.

The highest levels of nitrate and nitrite were in AW and AY (Group 1), while AJ and $\mathrm{CY}$ (Group 2) had the highest levels of phosphate. In all sampling sites, phosphate concentration exceeded the Indonesian government's water quality standard for fisheries of $0.2 \mathrm{PO}_{4}^{3-} \mathrm{mg} \mathrm{L}^{-1}$, with the highest concentration being recorded in Group $2\left(0.88 \mathrm{PO}_{4}{ }^{3-} \mathrm{mg} \mathrm{L}^{-1}\right)$.

Based on the government's regulations on water quality, the maximum levels of nitrate and nitrite in water should be $10 \mathrm{mg} \mathrm{NO}_{3}{ }^{-} \mathrm{L}^{-1}$ and $0.06 \mathrm{mg} \mathrm{NO}_{2}{ }^{-}$ $\mathrm{L}^{-1}$, respectively. In this study, nitrate was recorded at levels between 0.0035 and $0.70 \mathrm{NO}_{3}{ }^{-} \mathrm{mg} \mathrm{L}^{-1}$, with the highest level found in Group 1 and the lowest level in Group 3. Nitrite levels were 0.001-0.01 $\mathrm{mg} \mathrm{NO}_{2}^{-} \mathrm{L}^{-1}$, with the highest level measured in Group 1 and lowest in Group 3. Both levels were still within acceptable limits for fisheries. Nitrite is naturally found in levels much lower than those we recorded, however, less than $5 \mu \mathrm{g} \mathrm{L}^{-1} \mathrm{~N}$. NO 2 (Lewis and Morris 1986). Thus, it can be concluded that most of the sampling sites were polluted by sewage (Eddy and Williams 1987).

This study also recorded higher BOD in Groups 1 and 2, although both groups had significantly different levels, $5.11 \mathrm{mg} \mathrm{BOD} \mathrm{L}^{-1}$ in Group 1 to 8.23 BOD mg L ${ }^{-1}$ in Group 2, while group 3 had $3.11 \mathrm{mg} \mathrm{BOD} \mathrm{L}^{-1}$. All three groups failed to meet the government's standard for BOD, which is $3 \mathrm{mg} \mathrm{BOD} \mathrm{L}^{-1}$. In terms of COD, Group 2 also had significantly higher levels of COD compared with the other two groups, with $83.60 \mathrm{mg} \mathrm{COD} \mathrm{L}^{-1}$, while Group 3 had the lowest, with $23.29 \mathrm{mg}$ COD $\mathrm{L}^{-1}$. While Groups 1 and 3 hovered near the government's limit of $25 \mathrm{mg} \mathrm{COD} \mathrm{L}^{-1}$, Group 2's COD greatly exceeded it. High concentrations of BOD and COD in water may decrease the level of dissolved oxygen (DO), in turn making difficult for water biota to breathe. 
In all three groups, the average DO levels were almost $5 \mathrm{mg} \mathrm{L}^{-1}$. Levels of DO fluctuate throughout the day, with the highest level of DO occurring during the afternoon. Other factors that contribute to the level of DO are shading, turbidity, depth, temperature, and nutrient richness, which usually correlate negatively with DO concentrations in stagnant water bodies, ice-covered ponds, tropical swamps, polluted streams, deep oceanic layers, or high tidal pools filled with decaying seaweed (Kramer 1987). BPSDALH Provinsi Papua's (2009) study taking place between August and December, 2009, recorded higher DO levels in AJ, BP, and BAy, 6-8 mg DO L'- . A follow-up study in April-October, 2010, however, recorded concentrations closer to our own results, 4-6 mg DO L ${ }^{-1}$ (BPSDALH Provinsi Papua 2010). This fluctuation of DO in Lake Sentani might be related to time, season, and the aforementioned factors described by Kramer (1987). The distribution of DO in freshwater has a significant effect on fish

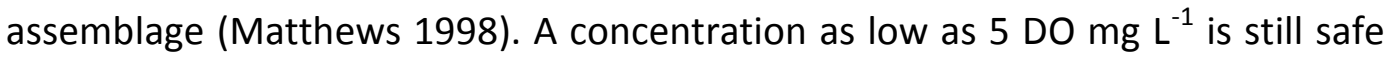
for fish, but most have been shown to avoid concentrations that approach or drop below 4 DO $\mathrm{mg} \mathrm{L}^{-1}$ (Wannamaker and Rice 2000; Spoor 1990). According to Burleson et al. (2001), Largemouth Bass (Micropterus salmoides) avoided water below $2.4 \mathrm{mg} \mathrm{DO} \mathrm{L}^{-1}$, although juveniles and smaller fish could tolerate or even prefer lower levels, while Wannamaker and Rice (2000) found that juvenile Brown Shrimp (Penaeus aztecus), Croaker (Micropogonias undulatus), Atlantic Menhaden (Brevoortia tyrannus), Mummichog (Fundulus heteroclitus), Pinfish (Lagodon rhomboides), Spot (Leiostomus xanthurus), and White Mullet (Mugil curema), would detect and respond to low levels of DO, either by avoiding the hypoxic area or performing aquatic surface respiration (in the case of the Mummichog). All of the species were able to detect concentrations as low as 1 DO $\mathrm{mg} \mathrm{L}^{-1}$, whilst showing a preference for higher concentrations when available, with the exception of the Croaker, Mummichog, and White Mullet, which

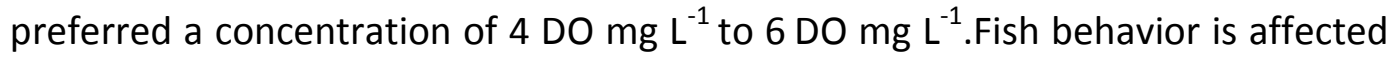
by reduced oxygen availability in water, including (1) a change in activity, such as feeding, avoidance, and ventilation frequency, (2) increased use of air-breathing, 
(3) increased use of aquatic surface respiration, and (4) vertical or horizontal movement within a habitat (Kramer 1987).

This study clearly shows that human activities around the lake led to a disturbance in its water quality. This was observed in all sampling sites in Groups 1 and 2. As has been noted elsewhere, increasing phosphate and nitrogen will enrich nutrients in water, supporting water plant and algae growth. Astuti and Satria (2009) found phytoplankton abundance in Lake Sentani to be 28.168246.464 individuals $\mathrm{L}^{-1}$, and suggested that phytoplankton abundance was correlated with nutrient enrichment, and Lake Sentani was categorized as eutrophic. A dense plankton population is one characteristic of a eutrophic lake, along with algal blooms (Odum 1971). Therefore, eutrophication would be the result of these characteristics. Nutrient enrichment in the lake during dry seasons was reported by the local communities to cause algal blooms and massive fish death. High nutrient concentrations in Group 1 and Group 2 led to increased Hydrilla verticillata (Esthwaite Waterweed) growth, along with Eichhornia crassipes (Water Hyacinth) in Group 1 and 3. In the past, the Water Hyacinth has caused serious problems for local community members using the lake for transportation.

\subsection{Red Rainbowfish Abundance in Lake Sentani and the Impact of Pollutants on Abundance}

The physicochemical analyses showed that, across all groups, there was a significant level of pollutants in Lake Sentani, in particular phosphate, nitrate, and nitrite. However, abundance analyses revealed no significant difference between the groups. That is to say, the pollutants seemed to have no significant impact on Red Rainbowfish abundance. The Red Rainbowfish has managed to cope with the pollution in Lake Sentani through its ability to adapt to changes in water quality. This ability supports its existence in the lake, in contrast to that of another endemic rainbowfish species, the Sentani Rainbowfish (Chilatherina sentaniensis), which appears to be more sensitive to habitat alteration, as it is no longer found in Lake Sentani, as well as in its last known habitat, Carwash Creek 
(AJ's Creek). Lake Sentani is a large water body, with a 10,400 ha surface area, and maximum depths of 52 and 43 meters, in the western and eastern halves, respectively (Howard 1987). Because of current turbulence created by temperature and wind exposure, which mixes the oxygen and food of different parts of a water body, aquatic environments are far more homogenous than terrestrial environments (Brönmark and Hansson 2005). In Lake Sentani, the turbulence likely also mixes water with high pollutant concentrations with water with lower concentrations, decreasing the effect of pollutants on the Red Rainbowfish. However, linear mixed-effect model analyses of each main pollutant revealed that only nitrate showed a significant (negative) impact on Red Rainbowfish abundance. Pearson's correlation coefficient further showed that an increase in nitrate caused a decline in abundance (Fig. 4.10), although the correlation was weak $(r=-0.231)$.

When analysis was based on sex, the results indicated that female fish had a different abundance between groups, with Groups 1 and 2 having significantly higher abundance than Group 3.

Nitrate is one of the significant components supporting lake enrichment, along with phosphate, which is mostly utilized by water plants and algae. Despite being responsible for nutrient enrichment, nitrate is harmful to water organisms in high concentrations, impacting the oxygen-carrying capacity of their blood and causing decreased oxygen consumption (Camargo et al. 2005; Tilak et al. 2007). Freshwater organisms are more sensitive to nitrate toxicity than marine organisms. Amongst freshwater fish, invertebrates, and amphibians, long exposures to nitrate at concentrations higher than $10 \mathrm{mg} \mathrm{L}^{-1}$ is potentially lethal, whereas marine animals are able to tolerate concentrations as high as $20 \mathrm{mg}$ $\mathrm{NO}_{3}{ }^{-} \mathrm{L}^{-1}$ (Camargo et al. 2005). Based on the Indonesian government's water quality regulations, $10 \mathrm{mg} \mathrm{NO}_{3} \mathrm{~L}^{-1}$ is the maximum permissible level of nitrate in drinking water and fisheries. The highest level we found was $0.71 \mathrm{mg} \mathrm{NO}_{3}{ }^{-\mathrm{L}^{-1}}$, well below the government's limit, as well as the limit of $2 \mathrm{mg} \mathrm{NO}_{3} \mathrm{~L}^{-1}$ found by 
Camargo et al. (2005) for the most sensitive freshwater species. Nevertheless, Red Rainbowfish abundance declined when concentrations of nitrate increased, albeit with a weak correlation.

Although nitrate was the only water parameter to impact the Red Rainbowfish in this survey, the uncontrolled input of pollutants into Lake Sentani's water in the future will increase its level of pollutants, including nitrate, nitrite, and phosphate. Nitrite and phosphate also have adverse effects on aquatic organisms. Nitrite is more toxic than nitrate, impacting the diet, oxygen transportation, and physiology of fish (Eddy and Williams 1987). It decreases hemoglobin and increases methemoglobin, the former of which results in lowered oxygen-carrying capacity in blood, and consequently decreased oxygen consumption (Tilak et al. 2007). After high nitrite exposure, Chinook Salmon (Oncorhynchus tshawytscha) and Rainbow Trout (Oncorhynchus mykiss) displayed behavioral signs of oxygen deprivation (Westin 1974), while nitrite was found to be far more toxic to Milkfish juveniles (Chanos chanos Forsskal) in freshwater, at a concentration of $12 \mathrm{mg} \mathrm{NO} \mathrm{N}_{2}-\mathrm{N} / \mathrm{I}$, than in $16 \mathrm{ppm}$ brackish water, at a concentration of $675 \mathrm{mg} \mathrm{NO}-\mathrm{N} / \mathrm{I}$ (Almendras 1987), and reduced Silver Perch (Bidyanus bidyanus) growth in concentrations above $1.43 \mathrm{mg} \mathrm{L}^{-1} \mathrm{NO}_{2-} . \mathrm{N}$ (Frances et al. 1998). Furthermore, phosphate and nitrogen are responsible for over-enrichment in lakes and rivers. Agriculture and urban activity, including industry, are a major source of phosphate and nitrogen. These compounds cause eutrophication, which has many negative impacts on aquatic ecosystems, such as water-use interference from increased algae and aquatic weed growth and increased fish kills from the oxygen depletion caused by their senescence and decomposition (Carpenter et al. 1998), as well as decreasing species diversity rapidly (Seehausen et al. 1997).

Increased nitrogen and phosphate in the future will threaten the Red Rainbowfish and its co-inhabitants in Lake Sentani. The likely consequence of their continued increase will be a decreasing Red Rainbowfish population, and 
eventually its extinction. Other fish species, as examples of the possible fate of the Red Rainbowfish, have been impacted by phosphate and nitrate and nitrite toxicity. Juvenile Channel Catfish (Ictalurus punctatus) showed reduced growth rates and increased mortality at $\geq 1.60 \mathrm{mg} \mathrm{NO}_{2}^{-} \mathrm{L}^{-1}$ and $\geq 3.71 \mathrm{mg} \mathrm{NO}_{2}^{-} \mathrm{L}^{-1}$, respectively (Colt et al. 1981). High nitrite caused a decrease in hemoglobin and increase in methemoglobin in the Common Carp (Cyprinus carpio), along with reduced oxygen consumption (Tilak et al. 2007). A nitrate concentration of $10 \mathrm{mg}$ $\mathrm{NO}_{3}^{-} \mathrm{L}^{-1}$ had a negative impact on the Rainbow Trout, Chinook Salmon, and Salmo clarki (Camargo, et al. 2005). It can be expected that fish will die after a long period of exposure to nitrate and nitrate. Meanwhile, in Udasaigar Lake in India, dissolved oxygen depletion because of effluents, sewage, and phosphate mining led to fish mortality (Das 1999). Agricultural waste-specifically fertilizer-sewage, and other human sources encouraged algal blooms, which exacerbated the process of euthropication. This process, and another threat factor, exotic fish species, contributed to the extinction of some native fish species in Lake Victoria (Primack 1998).

Human activities in terrestrial and aquatic ecosystems contribute to the increase of phosphate, nitrate, and nitrite in the latter ecosystem. Although the Red Rainbowfish was largely unaffected by the present concentrations of those pollutants in Lake Sentani, the continuing human population growth around the lake will result in concentrations that will be hazardous to the Red Rainbowfish and its co-inhabitants.

\subsection{Red Rainbowfish Body Length and the Impact of Pollutants on Body Length}

Water pollutants can have an effect on fish body growth. In this survey, however, we did not find a strong correlation between the pollutants and Red Rainbowfish body length. The longest Red Rainbowfish body size, with $70.72 \mathrm{~mm} \mathrm{SL}$, was observed in Group 3 (Table 4.5), which had better water quality than the other groups. Allen (1991) stated that Red Rainbowfish lengths reach $120 \mathrm{~mm}$ SL for males and $100 \mathrm{~mm} \mathrm{SL}$ for females, but fish of these lengths were rarely found in 
this study. Our inability to record fish with lengths matching those in Allen's findings may be due to our samples only being collected in shallow water. Analyses revealed a significant difference between groups in mean Red Rainbowfish body length, with Group 3 having the longest mean body length of the three groups. Better water quality in Group 3's locations may be the cause of the longer body lengths. Further analyses, however, showed that of all pollutants, only phosphate had a correlation with Red Rainbowfish body length (Table 4.7). Nonetheless, the correlation was not significant $(p=0.15)$. The other water parameters-temperature, $\mathrm{pH}, \mathrm{DO}, \mathrm{BOD}, \mathrm{COD}$, nitrate, and nitrite-made no contributions to body length. Thus, it could be concluded that the pollutants had no significant impact on the body length of the Red Rainbowfish.

With more than 30 individuals per site per visit during the three-year survey, the overall abundance of the Red Rainbowfish was high in Lake Sentani. However, physicochemical analysis of the water was conducted only in one sampling site per location, which is likely not adequate for a full analysis of its correlation with fish abundance and body length. Thus, the relatively low amount of water physicochemical parameter data may be the reason for the lack of a strong correlation between Red Rainbowfish abundance and body length, along with water physicochemical fluctuation throughout the year.

\subsection{Correlation between Red Rainbowfish and Introduced Fish}

Although there are many exotic fish in Lake Sentani and new species continue to be introduced, introduced fish abundance had a weak correlation with Red Rainbowfish abundance (Fig. 4.12-Fig. 4.14). Seven species of introduced fish were recorded during the survey: Tilapia (Oreochromis mossambicus), Hardlipped Barb (Osteochilus hasselti), Midas Cichlid (Amphilophus citrinellus), Red Breast Cichlid (A. longimanus), Striped Snakehead (Channa striata), Snakeskin Gourami (Trichogaster pectoralis), and Silver Barb (Puntius javanicus). Each species was rarely found in shallow waters (Fig. 4.11), except the Cichlids, 
A. citrinellus and $A$. longimanus, in some locations, particularly BAy and CR, in which they were abundant. Most of them were observed as juvenile individuals, suggesting that adult individuals occupied deeper areas of the lake. These species therefore had no significant impact on the abundance of the Red Rainbowfish.

There was a weak positive correlation between introduced species abundance and Red Rainbowfish abundance, especially in Group 1 and Group 3 (Fig. 4.12, Fig. 4.14). Red Rainbowfish abundance increased equally if the abundance of introduced fishes increased, although the increase was very small. Contrarily, a very weak negative correlation was found in Group 2 (Fig. 4.13). The exact reasons for the increase and decrease in Red Rainbowfish abundance in relation to an increase in introduced fish is beyond the scope of this study. However, it is possible that these species occupied different habitats vertically and different ecological niches. The preferred habitat of each species still provides sufficient resources, adequately supporting their population.

Generally, introduced fishes have adverse effects on native fishes, including predation, increased competition for resources, hybridization, and disease transmission (Hermoso et al. 2011; Gozlan et al. 2010; Arismendi et al. 2009; Vitule et al. 2009; Gozlan 2008; Dextrase and Mandrak 2006; Larsen et al. 2006; Canonico et al. 2005; Ogutu-Ohwayo 1990). Although these results showed no correlation between the abundance of introduced fish species and abundance of Red Rainbowfish, Allen (1991) argues that introduced fish species are one of the main threats to freshwater fish in New Guinea. An example of this occurring elsewhere is the Eastern Rainbowfish (Melanotaenia splendida splendida) in Australia. Reproductive activities of breeding groups of introduced Tilapia (Oreochromis mossambicus) severely impacted the spawning success of Eastern Rainbowfish (Doupé et al. 2009). Because Tilapia is also found in Lake Sentani, it is possible that the Red Rainbowfish and other native species may be affected by its presence, whether through habitat alteration or other means; however, there is presently no research on the impact of the Tilapia in Lake Sentani. 


\subsection{Sex Ratio of the Red Rainbowfish}

Red Rainbowfish along the shoreline of Lake Sentani were predominantly male. Sex ratios were similar across groups (M:F $=6-8: 1)$, with Group 3 having a slightly higher ratio, $M: F=8: 1$ (Table 4.8). Group 3 was much lower in female abundance than Group 1 and Group 2 (Table 4.3). Siby (2009) noted that female fish prefer to occupy deeper water amidst submerged water plants. Group 3's locations had no water plants, except for a small group of Water Hyacinth in BAy, BAs and BP. This may be the cause of the lower abundance of female Red Rainbowfish in Group 3 compared with the other two groups, both of which had dense submerged water plants, $H$. verticillata being the most abundant. Siby (2009) also found that Red Rainbowfish had a sex ratio of 1:1 in the months of December, April, and May, and 1:2.5 or 1:3 in the months of January and February. Siby's results were similar to those of Red Rainbowfish observed in captivity, which is 1:1, although different from ratios of other rainbowfish species, such as the Lake Tebera Rainbowfish (Melanotaenia herbertaxelrodi), which could have $100 \%$ males or females, depending on water temperature. Higher water temperature resulted in more males, while lower water temperature produced more females (Johannes Graf, pers. comm.). The different habitat preferences of male and female Red Rainbowfish might be a factor in the disparity between males and females sampled during this survey. Therefore, different methods of fish collection have to be used to determine sex ratios and the abundance of female Red Rainbowfish in Lake Sentani.

Although this study shows that there is an increase in pollutants in Lake Sentani, particularly in Groups 1 and 2, statistical analyses on the fish failed to detect serious impacts of these pollutants on Red Rainbowfish, with the exception of nitrate, which affected abundance. A number of other factors may have contributed to Red Rainbowfish abundance, such the physical conditions of the lake, food availability, substrate type, or presence of terrestrial or water 
vegetation. The former two factors, which were not part of this study, may be the subject of a future study..

\subsection{Red Rainbowfish Habitat Preferences}

Red Rainbowfish were found abundantly in sand, gravel, and cobble substrates, but rare in mud substrate (Fig. 4.15, Fig 4.16). Reasons for the substrate selection by the fish were not analyzed. However, selection may be related to food availability and predator avoidance. Gotceitas and Brown (1993) found that substrate selection by Atlantic Cod (Gadus morhua) is related to predation. The juvenile fish preferred sand or gravel-pebble when there was no risk of predation, and hiding in cobble substrate when predators were nearby. Meanwhile, the Three-spined Stickleback, Gasterosteus aculeatus, prefers specific substrates while foraging (Webster and Hart 2004). It prefers complex substrates (mixed sand-stone gravel) over simple substrates (sieved sand particles), even in cases when simple substrates have higher prey density. In experimental conditions, the Lake Sturgeon, Acipenser fulvescens, prefers sand substrate over gravel, rock, and smooth plastic, similar to its preference in the wild (Peake 1999). Habitat types were also determined by the existence of young fish in the littoral zone of Lake Müggelsee (Lewin et al. 2004).

The Red Rainbowfish prefers to shoal amongst water plants and terrestrial plants, the latter of which encompasses grasses and, more rarely, the roots of Sago Palms (Metroxylon sagu) along the shoreline. The presence of water and terrestrial vegetation were factors in Red Rainbowfish habitat selection, along with substrate type and food availability. Many Red Rainbowfish were observed searching for food amongst grasses, roots of Sago Palms, and Water Hyacinth. Wilde and Paulson (1989) found that fish abundance was more correlated with food abundance than physical water parameters. The existence of certain water

and terrestrial plants supported Red Rainbowfish abundance in its habitats. Overall, $H$. verticillata was the most common species. However, its presence or 
absence did not have a significant influence on Red Rainbowfish abundance, as abundance was not significantly different between locations with and without H. verticillata (Fig. 4.17). Contrarily, the presence of other water plants (Water Hyacinth), terrestrial plants (grasses and Sago Palms), and other habitat preferences (such as substrate type) supported Red Rainbowfish abundance. Water Hyacinth is a common water weed in freshwater ecosystems in Papua, and Lake Sentani is no exception, with the high level of phosphate in the lake contributing to the high density of the plant. A high input of nutrients will further increase population numbers of this plant, allowing it to extend as far as the shoreline and cause oxygen depletion in the water underneath it. Furthermore, the plant is reported to have negative social, economic, and environmental impacts in freshwater ecosystems (Baglioni 1959; Mailu 2001). In general, a DO concentration under $4 \mathrm{mg} \mathrm{L}^{-1}$ will be harmful for fishes (Matthews 1998). Thus, a dense population of this plant is detrimental to the Red Rainbowfish. However, in small groups and different parts of the shoreline, it able to attract Red Rainbowfish searching amongst its roots for food. The plant also has an additional positive role in water, such as removing color in wastewater, absorbing cadmium, arsenic, cyanide, mercury, nitrate, phosphate, and industrial and radioactive liquid waste, and serving as a biological indicator of heavy pollution in aquatic ecosystems (Tarawou et al. 2007; Nir et al. 1990; Marcus 1993; Wooten and Jodd 1976; Gossett and Norris 1971; Chigbo et al. 1982; Skinner et al. 2007; Hafez and Ramadan 2002; Pfeiffer et al. 1986). The Red Rainbowfish was also most commonly found around $H$. verticillata, and to a lesser extent, grasses, Vallisneria americana, and E. crassipes, probably to search for food and as refuge. Serafy and Harrell (1993) found high Banded Killifish (Fundulus diaphanus) densities in beds of $H$. verticillata, in particular, and $V$. americana, occupying them during the day and night as refuge and feeding areas. Hydrilla verticillata is an Old World plant that is widespread in Lake Sentani as a habitat to some native fish species, including the Red Rainbowfish. Except for disturbing water transportation in the lake (Sukarwo 1990), the 
negative impacts of the species on water organisms have so far gone unreported. Hattori and Warburton (2003) also showed that the Crimsonspotted Rainbowfish (Melanotaenia duboulayi) is more abundant in vegetated areas, with larger individuals using the plants as refuge and a food source, but did not enter Vallisneria beds, where predators were observed. Borg et al. (1997) also confirmed that water vegetation was a refuge from predation for juvenile Cod (Gadus morhua L.). Moreover, wood debris, which was influenced by lakeshore development (Marburg et al. 2006), was also important as a habitat for the Red Rainbowfish, as was the case with the Salmon (Oncorhynchus masou) in the Toikanbetsu Stream system and Pankenai Stream, whose abundance correlated positively with wood debris abundance (Inoue and Nakano 2001). Riparian vegetation was also significant, serving as a food source (pollen) and providing shade for the fish. Therefore, the existence of terrestrial vegetation is necessary for the survival of the Red Rainbowfish. Any habitat alteration along the shoreline that destroys water and terrestrial vegetation will have a negative impact on and threaten the Red Rainbowfish, as well as the other fishes occupying the area.

The Red Rainbowfish usually occupied very shallow waters, up to $200 \mathrm{~cm}$. Fish with smaller body lengths ( $<90 \mathrm{~mm} \mathrm{SL}$ ) tended to occupy the very shallow area near the shoreline, while fish with longer bodies ( $\geq 90 \mathrm{~mm} \mathrm{SL}$ ) were rare along the shoreline (Fig. 5.1). Red Rainbowfish were seldom caught by local fisherman with gill nets in the deeper parts of the lake. In Lake Constance, Germany, shallow areas were important for small species or juveniles of larger species. Turbulence in these areas was very high because of high wind and wave action, and might have prevented larger predators from preying on the small and juvenile fish, thus allowing them to use the shallow areas as a refuge (Fischer and Eckmann 1997). Moreover, Serafy and Harrell (1993) also found that shallow areas served as a refuge from predators and feeding area for smaller fish. Allen (1991) confirmed that rainbowfish species generally consume a variety of plant and animal items, 
which are all available in the shallow areas along shorelines. In the case of the Red Rainbowfish, these factors, turbulence and food availability, may be the reasons in their habitat selection.

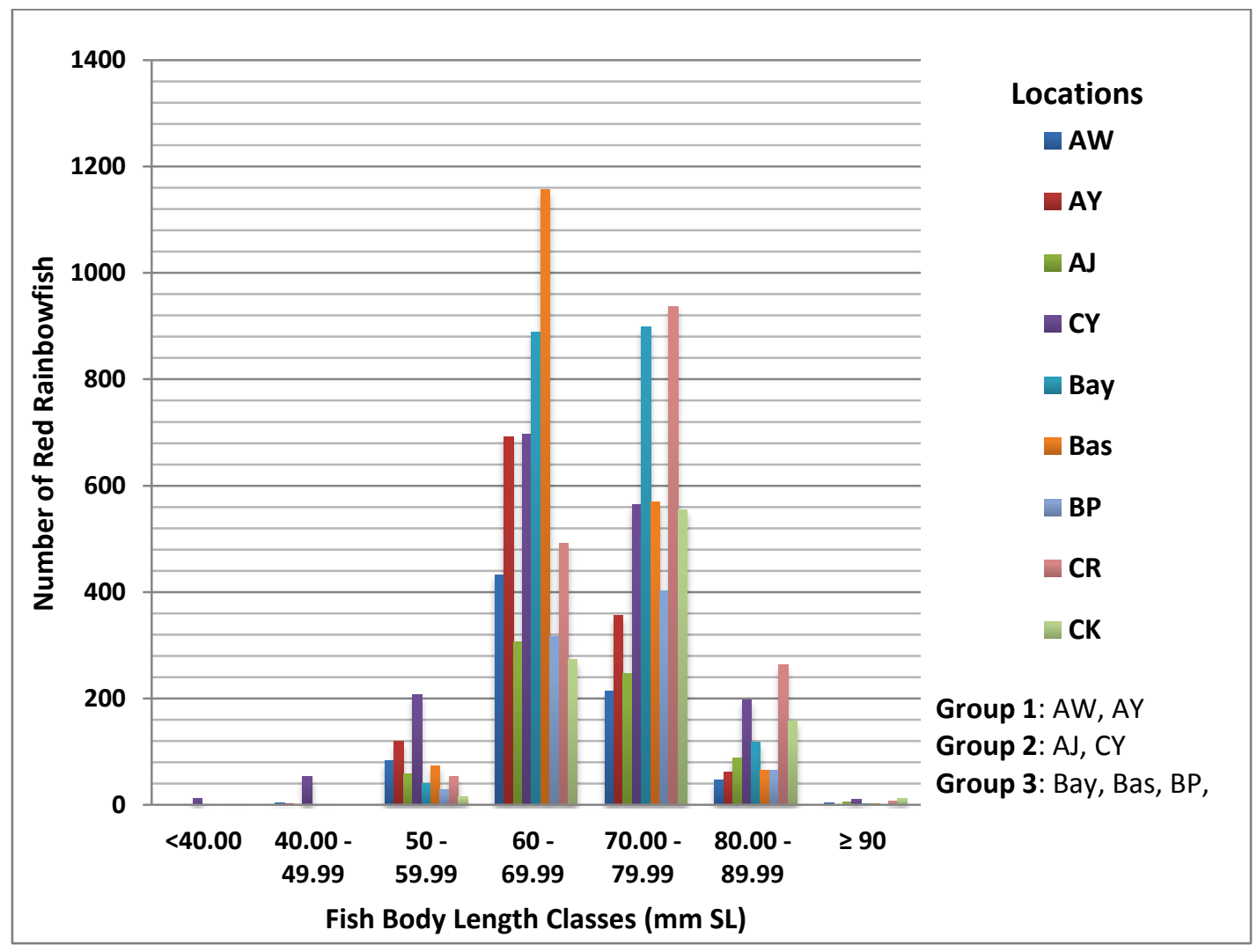

Fig. 5.1. Red Rainbowfish body length classes and its abundance in each location.

Although we found Red Rainbowfish in both clear water (5 NTU) and turbid water, they were predominantly found in clear water (Appendix 5). The only turbid waters in which they were found were the mouths of AW (Group 1) and AJ (Group 2) Creeks. The turbidity in these two locations was caused by erosion in the heads of the creeks and in the terrestrial areas along them, as the result of human activities. Some other rainbowfish species have also been found in still turbid or black tea water, such as Melanotaenia praecox, which is found in a small turbid creek in Mamberamo rainforest in Buare, Central Mamberamo, Papua; and Chilaterina fasciata and 
C. lorentzi in a turbid stream and creek in Haya at Van Rees Mountain, Mamberamo, while Glossolepis multisqumatus is only found in a small, blackcolored lake in Haya, Mamberamo as well. The Red Rainbowfish was observed up to 15 meters into the creeks in $\mathrm{AW}$ and $\mathrm{AJ}$; other lake-dwelling species of rainbowfish were found in tributaries, creeks, streams, and rivers. For instance, Melanotaenia ajamaruensis and $M$. boesemani are found in the Ayamura Lakes and their surrounding tributaries in the Bird's Head Peninsula, Papua; $M$. ajamaruensis is also found upstream in Kaliwensi River, about $5 \mathrm{~km}$ west of Ayamura Lake, while $M$. boesemani is also found in Tiwit Creek, less than $1 \mathrm{~km}$ north of Ayamura Lake (Kadarusman et al. 2010).

The Red Rainbowfish was found abundantly in the early morning, 06.00$09.00 \mathrm{am}$, and afternoon, 16.00-dark. It usually avoided high light intensities. Therefore, fish were rarely found in shallow waters during periods of high light intensity, such as from late-morning to mid-afternoon, having dived to deeper waters and shoaled near food sources. When they remained near the surface, they had moved to shadowed areas, such as under stilt houses or submerged plants. In contrast, juveniles and small fish of the Crimsonspotted Rainbowfish (M. duboulayi) shoal near the surface where it is warmest, even during the hottest time of day, feeding on floating material; in cloudy conditions, all sizes of the fish preferred deeper water (Hattori and Warburton 2003). Shaded areas can be used to avoid both higher temperatures and the sights of predators (Helfman 1981). In addition to the availability of food and turbulence, habitat selection of the Red Rainbowfish is probably also related to the spatial distribution of the temperature gradient in the lake, which is an important influence in the habitat selection of all fish (Matthews 1998). High temperatures broadly limited distributions of lentic and lotic fishes (Eaton et al. 1995). This shows that every single fish has a temperature range that limits their habitat selection or distribution in aquatic ecosystems. Moreover, gradients of oxygen and $\mathrm{pH}$ are also cues to fish habitat selection or avoidance (Matthews 1998). Therefore, the 
habitat selection of the Red Rainbowfish should be closely-related to abiotic factors, such as water temperature and food sources.

The habitat preferences of the Red Rainbowfish, including substrate types, and vegetation, contributed to its abundance, and these preferences serve as indicators of its habitat selection in Lake Sentani. Statistical analyses revealed no difference between groups in Red Rainbowfish abundance, despite the groups' different habitat conditions. Nevertheless, each group contained its preferred substrates, vegetation, and food sources, which may explain the consistency in abundance across groups, and further indicating that habitat preferences played a greater role in fish abundance than water quality.

\subsection{Conservation of the Red Rainbowfish}

The Red Rainbowfish is one of seven threatened rainbowfish species in Papua listed in the IUCN Red List of Threatened Species and is categorized as vulnerable (IUCN 2012; Allen 1996b). It has a very restricted range, less than 9,000 ha, and categorized as a restricted range species (Ohee 2005). This study revealed that the fish could still be found abundantly in the littoral zone up to a depth of 2 meters. However, habitat alteration occurred in almost all parts of Lake Sentani's littoral zone, especially near urban centers and along the provincial road. The only known habitat of the Red Rainbowfish is currently facing heavy humaninduced disturbances in the form of the establishment of settlements, restaurants, and harbors, public infrastructure development, land filling, road expansion, and domestic waste discharge. These activities threaten not just the Red Rainbowfish, but all of Lake Sentani's inhabitants. Habitat alteration in the lake has probably led to the near extinction of another endemic rainbowfish, the Sentani Rainbowfish (Chilatherina sentaniensis), in the wild. It is also one of the seven threatened rainbowfish species in Papua and has been categorized as Critically Endangered (CR) by IUCN, with its major threats being the domestic waste from increasing human populations near the lake, and the introduction of exotic species to the lake, such as Carp, Tilapia, Walking Catfish, Barbs, and 
Gouramies (Allen 1996a). The fish has not been found in Lake Sentani recently, and nor its last known habitat, Carwash Creek (AJ's Creek).

The increasing settlements around the lake belong mainly to people from outside of Jayapura and Sentani Regency seeking work and education, and accelerate habitat degradation around the lake. Moyle and Leidy (1992) have argued that five factors cause biodiversity loss in aquatic ecosystems: 1) competition for water; 2) habitat alteration; 3) pollution; 4) introduction of exotic species; and 5) commercial exploitation. At least three of the five causes, habitat alteration, pollution, and introduced exotic species, are currently happening in Lake Sentani. The human population in Sentani District also poses a problem. With a population and density of 47,758 and 598.47, respectively (Kantor Distrik Sentani 2009), population growth led to increases in 1) pollution from domestic waste in the lake, 2) introduced exotic species, either deliberately or accidentally, and 3) resource over-exploitation.

However, based on our observations, the biggest cause of habitat degradation was road expansion, which in some locations extended to the shoreline, although this was not the case in any of our survey locations. Vegetation in and near the shoreline was felled and land filled to build Papua's provincial road. Sedimentation was observed in the parts of the shoreline encroached on by the road, causing water turbidity and decreasing the water quality, and the habitats, feeding areas, and nursery grounds of the Red Rainbowfish and other native fish species, such as the Sentani Gudgeon (Oxyeleotris heterodon) and Snakehead Gudgeon (Giurus margaritaceus), both of which are the most important fish species to the local people, were damaged. Although the Red Rainbowfish was still abundant in Lake Sentani, the current rate of habitat alteration and degradation will likely threaten the species in the near future.

The physicochemical indicators of habitat alteration, increasing nitrate, nitrite, and phosphate, were from human activities around the lake. While nitrate and nitrite levels were still within acceptable limits, phosphate concentrations were 
high in all locations. We believe this result would need special attention in considerations of the future of the Red Rainbowfish, as well as Lake Sentani's other native fish species. One of the ways of mitigating the increase in phosphate and nitrogen would be for the local governments of Papua Province and Jayapura Regency to establish an awareness campaign on proper waste management.

Furthermore, both the central and local government should be made aware of Lake Sentani's ecological importance as Papua's largest lowland lake, as proposed by Conservation International (1999) and Polhemus et al. (2004), in order to protect its endemic and native species. Time is a critical factor in this respect, as quicker action may prevent further species extinction, which has already occurred with the Sawfish (Pristis microdon) and probably Sentani Rainbowfish.

Over two decades ago, Allen (1991) stated that Lake Sentani is one of the most endangered freshwater ecosystems in New Guinea, as the result of exotic species and population increase. He added that, even then, it was too late for it to be saved. Nevertheless, with proper and meaningful conservation efforts, an opportunity to protect the lake and its inhabitants still exists. Conservation efforts should focus on increasing local awareness of proper waste management, establishing community-based environmental initiatives, and educating policymakers of the ecological and cultural significance of Lake Sentani and its inhabitants. Finally, further research into the relation between the Red Rainbowfish and its habitat preferences may shed further light on their ecological relevance to both the Red Rainbowfish and Lake Sentani. 


\section{Conclusion}

This study revealed that the habitats of the Red Rainbowfish in Lake Sentani have suffered from degradation as the result of human activities, as shown in the levels of nitrate, nitrite, phosphate, biological oxygen demand (BOD) and chemical oxygen demand (COD) that exceeded the Indonesian government's limits. Two groups ( 1 and 2 ) were categorized as having heavy human impacts on the Red Rainbowfish's habitats, with Group 1 having the highest nitrate and nitrite levels and Group 2 having the highest phosphate, BOD and COD levels. The third group (3) had low to medium levels all five physicochemical parameters; thus, the impact of human activities in its locations was low. However, all but one pollutant had a negligible influence on the abundance of the Red Rainbowfish, which was similar across groups. The one exception was nitrate, of which increased concentrations had a significant negative correlation with abundance, albeit with a limited impact because nitrate levels were not very high. Instead, abundance was shown to have been more affected by habitat preference, including substrate type, vegetation, and food availability, suggesting that the Red Rainbowfish is able to tolerate the present level of pollution in Lake Sentani, although further increases in nitrate, nitrite, and phosphate through locals' continued deposition of organic waste into the lake, will have a detrimental and possibly irreversible effect on the species, along with the rest of the lake's fish community.

Body length, which is associated with abundance, was also largely unaffected by the pollutants in the lake. Only phosphate contributed to the body length of the Red Rainbowfish, but the effect was so low, that Group 3, with its higher overall water quality, had the highest mean body length, whereas Group 2 , with the highest concentrations of phosphate, had the second-highest mean body length. It is possible that there may be a correlation between habitat preference and Red Rainbowfish body length, and further research may shed light on whether this is the case. 
Contrary to our original assumption, males were far more abundant in shallow waters than females, who seemed to prefer the lake's deeper water. Female abundance tends to correlate with overall abundance, but this was not true of the Red Rainbowfish, where overall abundance was unaffected by the lack of females. The reason for females' depth preference is presently inconclusive. In captivity, where there is no variation in temperature and light, no depth preference has been observed. In Lake Sentani, these two factors may be the cause.

Correlations between introduced fish abundance and Red Rainbowfish abundance were very weak in all three groups; in Groups 1 and 3, a very weak positive correlation was found, whereas in 2 , we found a very weak negative correlation. Different abundances of different exotic species between groups, and specifically between Groups 1 and 3 and Group 2, is the likely cause of the positive and negative correlations, respectively, as well as the prevalence of adequate shelter or food, or lack thereof.

The habitat preferences of the Red Rainbowfish included sand, gravel, and cobble substrates; very shallow, clear waters (up to two meters); and Hydrilla verticillata, Eichhornia crassipes, Metroxylon sagu, and some grasses. These preferences affect its abundance, but not its survivability, as it was observed in areas that lacked them. Nevertheless, the importance of these vegetation and substrate types in providing shelter and food means they will continue to play a role in the future of the Red Rainbowfish in where it shoals and what it eats, and their continued prevalence enables it to thrive with very little risk of predation and starvation. Reducing the availability of these preferences will not only affect its abundance, but increase competition amongst the aquatic community for limited food and shelter sources, and increase predation on smaller fish such as the Red Rainbowfish.

Pollution in Lake Sentani has now made its water unsafe for human consumption. Despite that, human activities around the lake only contribute 
more organic and inorganic waste, further polluting it. So far, the Red Rainbowfish has managed to cope with the pollution through its ability to adapt to changes in water quality. However, it is only a matter of time before the level of pollution in the water makes the Lake Sentani uninhabitable, for both humans and aquatic organisms. This will also lead to the extinction of its three endemic fish species.

The results of this study provide baseline data for Red Rainbowfish conservation in Lake Sentani, and will supply policy-makers with a means of pursuing the protection of its habitats, create a strategy to control pollutants, and encourage community-based environmental management. Further research should investigate the roles and concentrations of other aquatic indicators of pollution, and the relationship between the Red Rainbowfish and its habitat preferences, as well as its susceptibility to certain types and concentrations of pollutants. Another research focus should be female Red Rainbowfish, specifically, and why their habitat preferences differ from those of males, in addition to the effect of females' different behavior on overall abundance. More broadly, other parts of Lake Sentani should be surveyed as a supplement to this research, and a lake-wide monitoring program should be established to understand the exact ecological and physicochemical condition of the lake. Only then, rehabilitation of its vast ecosystem may follow. 


\section{References}

Allen, G. R. 1980. "A Generic Classification of the Rainbowfishes (Family Melanotaeniidae)." Records of the Western Australian Museum 8 (3): 449-490.

. 1991. Field Guide to the Freshwater Fishes of New Guinea. Madang, Papua New Guinea: Christensen Research Institute.

. 1995. Rainbowfishes in Nature and in the Aquarium. Melle, Germany: Tetra-Verlag.

. 1996a. Chilatherina sentaniensis. In IUCN 2012. IUCN Red List of Threatened Species. Version 2012.2. Accessed November 7, 2012. http://www.iucnredlist.org/details/4631/0.

. 1996b. Glossolepis incisus. In IUCN 2012. IUCN Red List of

Threatened Species. Version 2012.1. Accessed October 11, 2012. http://www.iucnredlist.org/details/9268/0.

1996c. Melanotaenia boesemani. In IUCN 2012. IUCN Red List of

Threatened Species. Version 2012.2. Accessed November 7, 2012. http://www.iucnredlist.org/details/13058/0.

1996d. Chilatherina bleheri. In UCN 2012. IUCN Red List of Threatened Species. Version 2012.2. Accessed June 20, 2013. http://www.iucnredlist .org/details/4629/0.

1996e. Melanotaenia parva. In IUCN 2012. IUCN Red List of Threatened Species. Version 2012.2. Accessed June 20, 2013. http://www.iucnredlist .org/details/13072/0.

. 1998. "A new genus and species of rainbowfish (Melanotaeniidae) from fresh waters of Irian Jaya, Indonesia." Revue fr. Aquariol. 25 (1-2): 11-15.

2001. "Lentipes multiradiatus, a new species of freshwater goby (Gobiidae) from Irian Jaya, Indonesia." Aqua 4 (3): 121-124.

Allen, G. R., and N. J. Cross. 1980. "Description of five new rainbowfishes (Melanotaeniidae) from New Guinea." Records of the Western Australian Museum 8 (3): 377-396.

1982. "Rainbow Fishes of Australia and Papua New Guinea." Australia: Angus \& Robertson. 
Allen G. R. and R. K. Hadiaty. 2011. "A New Species of Rainbowfish (Melanotaeniidae) from Western New Guinea (West Papua Province, Indonesia)." Fishes of Sahul 25 (1): 602-607.

Allen, G. R., H. L. Ohee, P. Boli, R. Bawole, and M. Warpur. 2002. "Fishes of the Yongsu and Dabra areas, Papua, Indonesia." In A Biodiversity Assessment of the Yongsu - Cyclops Mountains and the Southern Mamberamo Basin, Northern Papua, Indonesia, edited by S. J. Richards and S. Suryadi. RAP Bulletin of Biological Assessment 25. Washington, DC, USA: Conservation International.

Allen, G. R., and S. J. Renyaan. 1995. Survey of the Freshwater Fishes of Irian Jaya Phase I-1995, Interim Research Report. Western Australian Museum and Universitas Cenderawasih.

1996a. "Three New Species of Rainbowfishes (Melanotaeniidae) from the Triton Lakes, Irian Jaya, New Guinea." Aqua 2 (2): 13-24.

1996b. "Chilaterina pricei, a new species of rainbowfish (Melanotaeniidae) from Irian Jaya." Revue fr. Aquariol. 23 (1-2): 5-8.

1998a. Survey of the Freshwater Fishes of Irian Jaya Phase II (B) - 1998 Fishes of the Raja Ampat Islands, Interim Research Report. Western Australian Museum and Universitas Cenderawasih.

1998b. "Three new species of rainbowfishes (Melanotaeniidae) from Irian Jaya, Indonesia." Aqua 3 (2): 69-80.

2000a. "Fishes of the Wapoga River System, Northwestern Irian Jaya, Indonesia." In A biological assessment of the Wapoga river area of northwestern Irian Jaya, Indonesia, edited by A. L. Mack and L. E. Alonso. RAP Bulletin of Biological Assessment 14. Washington, DC, USA: Conservation International.

2000b. Survey of the Freshwater Fishes of Irian Jaya: Fishes of the Raja Ampat Islands, Misool Island, and South-Central Vogelkop Peninsula, Interim Research Report. Western Australian Museum and Universitas Cenderawasih.

Allen, G. R., and P. J. Unmack. 2008. "A new species of rainbowfish (Melanotaeniidae: Melanotaenia), from Batanta Island, Western New Guinea." Aqua 13 (3-4): $109-120$.

- 2012. "A new species of Rainbowfish (CHILATHERINA: Melanotaeniidae), from the Sepik River System of Papua New Guinea." Aqua 18 (4): 227-237. 
Allen, G. R., P. J. Unmack, and R. K. Hadiaty. 2008. "Two new species of rainbowfishes (Melanotaenia: Melanotaeniidae), from western New Guinea (Papua Barat Province, Indonesia)." Aqua 14 (4): 209-224.

Allison, A. 2007. "Introduction to the Fauna of Papua." In The Ecology of Papua: Part One, vol. 6 of The Ecology of Indonesia Series, edited by A. J. Marshall and B. M. Beehler. Singapore: Periplus Editions.

Almendras, J. M. E. 1987. "Acute Nitrite Toxicity and Methemoglobinemia in Juvenile Milkfish (Chanos chanos Forsskal)." Aquaculture 61: 33-40.

APHA (American Public Health Association), AWWA (American Water Works Association), and WPCF (Water Pollution Control Federation). 1980. Standard Methods for the Examination of Water and Wastewater, $15^{\text {th }}$ edition. Washington, DC, USA: APHA, AWWA, and WPCF.

Arismendi, I., D. Soto, B. Penaluna, C. Jara, C. Leal, and J. L. Muñoz. 2009. "Aquaculture, non-native Salmonid invasions and associated declines of native fishes in Northern Patagonian lakes." Freshwater Biology 54: 11351147.

Astuti, P., and H. Satria. 2009. "Kelimpahan dan Komposisi Fitoplankton di Danau Sentani, Papua." Limnotek 16 (2): 88-98.

Baglioni, C. 1959. "Effects of the Water Hyacinth (Eichornia crassipes) in the Nile Valley." Nature 492: 1085-1086.

BAPEDALDA (Badan Pengendalian Dampak Lingkungan Daerah) Kabupaten Jayapura. 2005. Pemeriksaan kualitas air Danau Sentani. Jayapura, Papua: BAPEDALDA Kabupaten Jayapura.

BAPEDALDA (Badan Pengendalian Dampak Lingkungan Daerah) Provinsi Papua dan LPPM-ITB. 2004. Laporan Akhir Studi ekosistem kawasan Danau Sentani Proyek Pengendalian Kerusakan Sumberdaya Alam kawasan perbatasan di Kabupaten Jayapura, Merauke, dan Jayawijaya. Bandung, Indonesia: Badan Pengendalian Dampak Lingkungan Daerah Provinsi Papua dan LPPM-ITB.

BAPPENAS (Badan Perencanaan dan Pembangunan Nasional). 2003. Strategi dan Rencana Aksi Keanekaragaman Hayati Indonesia 2003-2020 IBSAP Dokumen Regional. Jakarta, Indonesia: BAPPENAS.

Beehler, B. 2007. "Introduction to Papua." In The Ecology of Papua: Part One, vol. 6 of The Ecology of Indonesia Series, edited by A. J. Marshall and B. M. Beehler. Singapore: Periplus Editions. 
Borg, A., L. Phil, and H. Wennhage. 1997. "Habitat choice by juvenile cod (Gadus morhua L.) on sandy soft bottoms with different vegetation types." Helgoländer Meeresunters. 51: 197-212.

BP3D (Badan Perencanaan dan Pengendalian Pembangunan Daerah) Provinsi Papua. 2003. Gambar peta kabupaten di Provinsi Papua. Jayapura, Indonesia: BP3D Provinsi Papua.

BP3D dan BPS Provinsi Papua. 2003. Papua dalam angka 2002. Jayapura, Papua: BP3D dan BPS Provinsi Papua.

BPS (Badan Pusat Statistik). 2010. Hasil Sensus Penduduk 2010 Data Agregat per Provinsi. Jakarta, Indonesia: Badan Pusat Statistik.

BPS (Badan Pusat Statistik) Kabupaten Jayapura. 2010. Kabupaten Jayapura dalam Angka 2010. Jayapura, Indonesia: Badan Pusat Statistik Kabupaten Jayapura.

BPS (Badan Pusat Statistik) Provinsi Papua. 2012. Papua dalam Angka 2012. Jayapura, Indonesia: Badan Pusat Statistik Provinsi Papua.

BPS (Badan Pusat Statistik) Provinsi Papua Barat. 2012. Papua Barat dalam Angka 2012. Manokwari, Indonesia: Badan Pusat Statistik Provinsi Papua Barat.

BPSDALH (Badan Pengelolaan Sumber Daya Alam dan Lingkungan Hidup) Provinsi Papua. 2009. Laporan Akhir Pemantauan Kualitas Air Danau Sentani, Jayapura. Indonesia: Badan Pengelolaan Sumber Daya Alam dan Lingkungan Hidup Provinsi Papua.

Br. Surbakti, S., and E. R. P. F. Ramandey. 2010. "Eksplorasi dan identifikasi jenisjenis mollusca di Cagar Alam Cyclop serta Pemanfaatannya oleh asyarakat yang bermukim di sekitar Danau Sentani dan Daerah - Daerah Aliran Sungai (DAS) Jayapura." Universitas Cenderawasih.

Brönmark, C., and L-A. Hansson. 2005. The Biology of Lakes and Ponds, $2^{\text {nd }}$ edition. New York, USA: Oxford University Press.

Burleson, M. L., D. R. Wilhelm, and N. J. Smatresk. 2001. "The Influence of fish size on the avoidance of hypoxia and oxygen selection by largemouth bass." Journal of Fish Biology 59: 1336-1349.

Camargo, J. A., A. Alonso, and A. Salamanca. 2005. "Nitrate toxicity to aquatic animals: a review with new data for freshwater invertebrates." Chemosphere 58: 1255-1267. 
Canonico, G. C., A. Arthington, J. K. Mccrary, and M. L. Thiemes. 2005. "The effects of introduced tilapias on native biodiversity." Aquatic Conservation: Marine and Freshwater Ecosystems 15: 463-483.

Carpenter, S. R., N. F. Caraco, D. L. Correll, R. W. Howarth, A. N. Sharpley, and V. H. Smith. 1998. "Nonpoint pollution of surface waters with phosphorus and nitrogen." Ecological Applications 8 (3): 559-568.

Chigbo, F. E., R. W. Smith, and F. L. Shore. 1982. "Uptake of arsenic, cadmium, lead and mercury from polluted waters by the water hyacinth Eichornia crassipes." Environmental Pollution (Series A) 27: 31-36.

Colt, J., R. Ludwig, G. Tchobanoglous, and J. J. Cech, Jr. 1981. "The effects of nitrite on the short-term growth and survival of Channel Catfish, Ictalurus punctatus." Aquaculture 24: 111-122.

Compagno, L. J. V., S. F. Cook, and S. L. Fowler. 2006. Pristis microdon. In IUCN 2012. IUCN Red List of Threatened Species. Version 2012.2. Accessed January 10, 2013. http://www.iucnredlist.org/details/18174/0.

Conservation International. 1999. Laporan akhir lokakarya penentuan prioritas konservasi keanekaragaman hayati Irian Jaya. Washington, DC, USA: Conservation International.

Das, B. K. 1999. "Environmental pollution of Udaisagar Lake and impact of phosphate mine, Udaipur, Rajasthan, India." Environmental Geology 38 (3): 244-248.

de Fretes, Y. 2007. "The protected area system in Papua." In The Ecology of Papua: Part Two, vol. 6 of The Ecology of Indonesia Series, edited by A. J. Marshall and B. M. Beehler. Singapore: Periplus Editions.

Dextrase, A. J., and N. E. Mandrak. 2006. "Impacts of alien invasive species Of freshwater fauna at risk in Canada." Biological Invasions 8: 13-24.

Doupé, R. G., J. Schaffer, M. J. Knott, and D. W. Burrows. 2009. "How might an exotic fish disrupt spawning success in a sympatric native species?" Marine and Freshwater Research $60:$ 379-383.

Eaton, J. G., J. H. McCormick, H. G. Stefan, and M. Hondzo. 1995. "Extreme value analysis of a fish/temperature field database." Ecological Engineering 4: 289-305.

Eddy, F. B., and E. M. Williams. 1987. "Nitrite and Freshwater Fish." Chemistry and Ecology 3: 1-38. 
FAO (Food and Agriculture Organization) of the United Nations. 1972. Inland fisheries development in West Irian - report on Project Results Conclusions and Recommendations. Roma: FAO.

Fischer, P., and R. Eckmann. 1997. "Spatial distribution of littoral fish species in a large European Lake, Lake Constance, Germany." Archiv für Hydrobiologie 140 (1): 91-116.

Frances, J., G. L. Allan, and B. F. Nowak. 1998. "The effects of nitrite on the shortterm growth of silver perch (Bidyanus bidyanus)." Aquaculture 163: 6372 .

Gotceitas, V., and J. A. Brown. 1993. "Substrate selection by juvenile Atlantic cod (Gadus morhua): effects of predation risk." Oecologia 93: 31-37.

Gozlan, R. E. 2008. "Introduction of non-native freshwater fish: is it all bad?" Fish and Fisheries 9: 106-115.

Gozlan, R. E., J. R. Britton, I. Cowx, and G. H. Copp. 2010. "Current knowledge on non-native freshwater fish introductions." Journal of Fish Biology 76: 751786.

Gossett, D. R., and W. E. Norris, Jr. 1971. "Relationship between nutrient availability and content of nitrogen and phosphorus in tissues of the aquatic macrophyte, Eichornia crassipes (Mart.) Solms." Hydrobiologia 38 (1): 15-28.

Graf, J. 2010. Die Gattung Glossolepis/The genus Glossolepis/Het ges/acht Glossolepis. Solingen, Germany: Verlag Natur \& Wissenschaft.

Gray, N. F. 1989. Biology of Wastewater Treatment. New York, USA: Oxford University Press.

Hafez, M. B., and Y. S. Ramadan. 2002. "Treatment of radioactive and industrial liquid wastes by Eichornia crassipes." Journal of Radioanalytical and Nuclear Chemistry 252 (3): 537-540.

Hattori, A. and K. Warburton. 2003. "Microhabitat use by the rainbowfish Melanotaenia duboulayi in a subtropical Australian stream." Journal of Ethology 21: 15-22.

Helfman, G. S. 1981. "The Advantage to Fishes of Hovering in Shade." Copeia 2: 392-400. 
Hellawell, J. M. 1986. Biological Indicators of Freshwater Pollution and Environmental Management. London, England: Elsevier.

Hermoso, V., M. Clavero, F. Blanco-Garrido, and J. Prenda. 2011. "Invasive species and habitat degradation in Iberian streams: an analysis of their role in freshwater fish diversity loss." Ecological Applications 21 (1): 175188.

Hieronimus, H. 2002. Regenbogenfische und verandte Familien/All Rainbows and related Families. Morfelden-Walldorf, Germany: Verlag A.C.S.

Hilbe, J. M. 2011. Negative Binomial Rregression, $2^{\text {nd }}$ edition. Cambridge, England: Cambridge University Press.

Hill, D., M. Fasham, G. Tucker, M. Shewry, and P. Shaw, eds. 2005. Handbook of biodiversity methods survey, evaluation and monitoring. New York, USA: Cambridge University Press.

Howard, K. T. 1987. Inland Fisheries Development Irian Jaya. Jakarta, Indonesia: Government of the Republic of Indonesia and UNDP.

Inoue, M., and S. Nakano. 2001. "Fish abundance and habitat relationships in forest and grassland streams, northern Hokkaido, Japan." Ecological Research 16: 233-247.

IUCN 2012. IUCN Red List of Threatened Species. Version 2012.2.

Accessed November 7, 2012. http://www.iucnredlist.org.

Kadarusman, R. K. Hadiaty, G. Segura, G. S. Wibawa, D. Caruso, and J. Pouyaud. 2012. "Four new species of Rainbowfishes (Melanotaeniidae) from Arguni Bay, West Papua, Indonesia." Cybium, 36 (2): 369-382.

Kadarusman, Sudarto, E. Paradis, and L. Pouyaud. 2010. "Description of Melanotaenia fasinensis, a new species of Rainbowfish (Melanotaeniidae) from West Papua, Indonesia with comments on the rediscovery of $M$. ajamaruensis and the endangered status of M. parva." Cybium 34 (2): 207-215.

Kadarusman, Sudarto, J. Slembrouck, and L. Pouyaud. 2011. "Description of Melanotaenia salawati, a new species of rainbowfish (Melanotaeniidae) from Salawati Island, West Papua, Indonesia." Cybium 35 (3): 223-230.

Kantor Distrik Sentani. 2009. Profil Distrik Sentani. Sentani: Kantor Distrik Sentani. 
Kaufman, L. and P. J. Rousseeuw. 1990. Finding Groups in Data: an Introduction to Cluster Analysis. New Jersey, USA: John Wiley \& Sons.

Kouamélan, E. P., G. G. Teugels, V. N’Douba, G.G. Bi, and T. Koné. 2003. “Fish diversity and its relationships with environmental variables in a West African Basin." Hydrobiologia 505: 139-146.

Kramer, D. L. 1987. "Dissolved Oxygen and Fish Behavior." Environmental Biology of Fishes 18 (2): 81-92.

Larsen, B. M., O. T. Sandlund, H. M. Berger, and T. Hesthage. 2006. "Invasives, Introductions and Acidification: The Dynamics of a Stressed River Fish Community." Water, Air, and Soil Pollution: Focus. doi: 10.1007/s11267006-9073y.

Lewin, W-C, N. Okun, and T. Mehner. 2004. "Determinants of the distribution of juvenile fish in the littoral area of a shallow lake." Freshwater Biology 49: 410-424.

Lewis, W. M., and D. P. Morris. 1986. "Toxicity of Nitrite to Fish: A Review." Transactions of the American Fisheries Society 115: 183-195.

Mack, A. L., and L. E. Alonso, eds. 2000. A biological assessment of the Wapoga river area of northwestern Irian Jaya, Indonesia. RAP Bulletin of Biological Assessment 14. Washington, DC, USA: Conservation International.

Mailu, A. M. 2001. Preliminary Assessment of the Social, Economic and Environmental Impacts of Water Hyacinth in the Lake Victoria Basin and the Status of Control. Nairobi, Kenya: Kenya Agricultural Research Institute.

Marburg, A. E., M. G. Turner, and T. K. Kratz. 2006. "Natural and anthropogenic variation in coarse wood among and within Lakes." Journal of Ecology 94: 558-568.

Marcus, G. 1993. "Cyanide degradation by water hyacinths, Eichornia crassipes (Mart.) Solms." Biotechnology Letters 15 (10): 1085-1090.

Marshall, A. J. 2007. "The Diversity and Conservation of Papua's Ecosystems." In The Ecology of Papua: Part Two, vol. 6 of The Ecology of Indonesia Series, edited by A. J. Marshall and B. M. Beehler. Singapore: Periplus Editions.

Matthews, W. J. 1998. Patterns in Freshwater Fish Ecology. Norwell, USA: Kluwer Academic Publishers. 
McGuigan, K., D. Zhu, G. R. Allen, and C. Moritz. 2000. "Phylogenetic relationships and historical biogeography of melanotaeniid fishes in Australia and New Guinea." Marine \& Freshwater Research 51: 713-723.

Moyle, P. B., and R. A. Leidy. 1992. "Loss of Biodiversity in Aquatic Systems: Evidence from Fish Fauna" In Conservation Biology: The Theory and Preservation and Management, edited by P. L. Fiedler and S. K. Jain. New York, USA: Chapman \& Hall.

Moyle, P. B., and F. R. Senanayake. 1984. "Resource partitioning among the fishes of rainforest streams in Sri Lanka." Journal of Zoology 202: 195223.

Myre, E. and R. Shaw. 2006. "The Turbidity Tube: Simple and Accurate Measurement of Turbidity in the Field." Department of civil and environmental engineering, Michigan Technological University.

Nelson, J. S. 2006. Fishes of the World, $4^{\text {th }}$ edition. New Jersey, USA: John Wiley \& Sons.

Nir, R., A. Gasith, and A. S. Perry. 1990. "Cadmium Uptake and Toxicity to Water Hyacinth: Effect of Repeated Exposures Under Controlled Conditions." Bulletin of Environmental Contamination and Toxicology 44: 149-157.

Odum, E. P. 1971. Fundamentals of Ecology, $3^{\text {rd }}$ edition. Philadelphia, USA: W. B. Saunders.

Ogutu-Ohwahyo, R. 1990. "The reduction in fish species diversity in Lakes Victoria and Kyoga (East Africa) following human exploitation and introduction of non-native species." Journal of Fish Biology 37 (A): 207208.

Ohee, H. L. 2005. Pendekatan penilaian status konservasi jenis pada ikan pelangi endemik Papua dan konservasi habitatnya (master thesis). Depok, Indonesia: Universitas Indonesia.

Orrego, R., S. M. Adams, R. Barra, G. Chiang, and J. F. Gavilan. 2009. "Patterns of fish community composition along a river affected by agricultural and urban disturbance in South-Central Chile." Hydrobiologia 620: 35-46.

Peake, S. 1999. "Substrate preferences of juvenile hatchery-reared lake sturgeon, Acipenser fulvescens." Environmental Biology of Fishes 56: 367-374. 
Petocz, R. G. 1987. Konservasi alam dan pembangunan di Irian Jaya: Strategi pemanfaatan sumber daya alam secara rasional. Jakarta, Indonesia: Pustaka Grafitipers.

Pfeiffer, W. C., M., Fiszman, O. Malm, and J. M. Azcue. 1986. "Heavy metal pollution in the Paraiba do Sul River, Brazil." The Science of the Total Environment 58: 73-79.

Pison, G., A. Struyf and P. J. Rousseeuw. 1999. "Displaying a Clustering with CLUSPLOT." Computational Statistics and Data Analysis 30: 381-392.

Polhemus, D. A., R. A. Englund, and G. R. Allen. 2004. Freshwater Biotas of New Guinea and Nearby Islands: an Analysis of Endemism, Richness, and Threats. Washington, DC, USA: Conservation International.

Portt, C. B., G. A. Coker, D. L. Ming, and R. G. Randall. 2006. A review of fish sampling methods commonly used in Canadian freshwater habitats. Canadian Technical Report of Fisheries and Aquatic Sciences 2604. Ottawa: Fisheries and Oceans Canada.

Primack, R. B. 1998. Essentials of Conservation Biology, $2^{\text {nd }}$ edition. Massachusetts, USA: Sinauer Associates.

Pusey, B., M. Kennard, and A. Arthington. 2004. Freshwater Fishes of North Eastern Australia. Collingwood, Australia: CSIRO Publishing.

R Development Core Team. 2011. R: a language and environment for statistical computing. Vienna, Austria: $\mathrm{R}$ Foundation for Statistical Computing. http://www.R-project.org/.

-2012. $R$ : a language and environment for statistical computing. Vienna, Austria: R Foundation for Statistical Computing. ISBN: 3-900051-07-0. http://www.R-project.org/.

Renyaan, S. J. 1993. "The Freshwater Fishes of Sentani Lake, Jayapura, Irian Jaya." In Proceedings of the Biological Society of New Guinea, edited by R. Hoeft. Lae, Papua New Guinea: WAU Ecology Institute.

Richards, S. J., and S. Suryadi, eds. 2002. A Biodiversity Assessment of the Yongsu - Cyclops Mountains and the Southern Mamberamo Basin, Northern Papua, Indonesia. RAP Bulletin of Biological Assessment 25. Washington, DC, USA: Conservation International. 
Saeed, B., W. Ivantsoff, and G. R. Allen. 1989. "Taxonomic revision of the family Pseudomugiliidae (Order Atheriniformes)." Australian Journal of Marine \& Freshwater Research 40: 719-734.

Sekretaris Negara Republik Indonesia. 2001. Peraturan Pemerintah Republik Indonesia Nomor 82 tahun 2001 tentang pengelolaan kualitas air dan pengendalian pencemaran air. Jakarta: Sekretaris Negara Republik Indonesia.

Seehausen, O., J. J. M. van Alphen, and F. Witte. 1997. "Cichlid fish diversity threatened by eutrophication that curbs sexual selection." Science 277 : 1808-1811.

Serafy, J. E., and R. M. Harrell. 1993. "Behavioural response of fishes to increasing $\mathrm{pH}$ and dissolved oxygen: field and laboratory observations." Freshwater Biology 30: 53-61.

Siby, L. S. 2009. Biologi reproduksi Ikan Pelangi Merah (Glossolepis incisus, Weber 1907) di Danau Sentani. Bogor, Indonesia: Sekolah Pascasarjana Institut Pertanian Bogor.

Simbala, H.E.I. 2000. Kajian tingkat pencemaran air Danau Sentani Irian Jaya (master thesis). Manado, Indonesia: Universitas Sam Ratulangi.

Skinner, K., N. Wright, and E. Porter-Goff. 2007. "Mercury uptake and accumulation by four species of aquatic plants." Environmental pollution 145: 234-237.

Søndergaard, M., and E. Jeppesen. 2007. "Anthropogenic impacts on lake and stream ecosystems, and approaches to restoration." Journal of Applied Ecology 44: 1089-1094.

Spoor, W. A. 1990. "Distribution of fingerling brook trout, Salvelinus fontinalis (Mitchill), in dissolved oxygen concentration gradients." Journal Fish Bioogy 36: 363-373.

Sukarwo, P. 1990. Analisa vegetasi gulma air di Danau Sentani Jayapura, Irian Jaya. Manokwari, Indonesia: Fakultas Pertanian UNCEN.

Sutherland, W. J., ed. 1996. Ecological Census Techniques. Cambridge, UK: Cambridge University Press.

Sumantri, H. 2002. Laporan analisis spasial kondisi penutupan hutan di Papua dan perubahannya. Jayapura, Indonesia: Conservation International. 
Tappin, A. R. 2012. "Rainbowfish Species." Accessed January 9, 2013. http://rainbowfish.angfaqld.org.au/Melano.htm

Tarawou, T., M. Horsfall Jr., and J. L. Vicente. 2007. "Adsorption of Methyl Red by Water-Hyacinth (Eichornia crassipes) Biomass." Chemistry and Biodiversity 4: 2236-2245.

Tawari-Fufeyin, P., and S. A. Ekaye. 2007. "Fish species diversity as indicator of pollution in Ikpoba River, Benin City, Nigeria." Reviews in Fish Biology and Fisheries 17: 21-30.

Tilak, K. S., K. Veeraiah, and J. M. P. Raju. 2007. "Effects of ammonia, nitrite and nitrate on hemoglobin content and oxygen consumption of freshwater fish, Cyprinus carpio (Linnaeus)." Journal of Environmental Biology. 28 (1): 45-47.

Tim peneliti Biologi Universitas Cenderawasih (UNCEN). 2008. Survey Biodiversitas Kampung Buare, Kecamatan Mamberamo Hulu, Kabupaten Mamberamo Tengah. Jayapura, Indonesia: UNCEN.

Troell, M., and H. Berg. 1997. "Cage fish farming in the tropical Lake Kariba, Zimbabwe: impact and biogeochemical changes in sediment." Aquaculture Research 28: 527-544.

Umar, C., E. S. Kartamihardja, D. W. H. Tjahyo, Mujianto, L. P. Astuti, Y. Sugianti, N. Widarmanto, S. Romdom, U. Sukandi, and E. Kosasih. 2005. Laporan Tahunan Identifikasi dan karakteristik habitat dan populasi ikan di Danau Sentani Propinsi Papua. Jakarta, Indonesia: Badan riset kelautan dan perikanan Departemen Perikanan dan Kelautan.

Vila-Gispert, A., E. Garcia-Berthou, and R. Moreno-Amich. 2002. "Fish zonation in a Mediterranean stream: Effects of human disturbances." Aquatic Sciences 64: 163-170.

Vitule, J. R. S., C. A. Freire, and D. Simberloff. 2009. "Introduction of non-native freshwater fish can certainly be bad." Fish and Fisheries 10: 98-108.

Wanamaker, C. M., and J. A. Rice. 2000. "Effects of hypoxia on movements and behavior of selected estuarine organisms from the southeastern United States." Journal of Experimental Marine Biology and Ecology 249: 145163.

Watson, R. E., and G. R. Allen. 1999. "New species of freshwater gobies from Irian Jaya, Indonesia (teleostei: gobioidei: sicydiinae)." Aqua 3 (3): 113118. 
Webster, M. M., and P. J. B. Hart. 2004. "Substrate discrimination and preference in foraging fish." Animal Behaviour 68: 1071-1077.

Westin, D.T. 1974. "Nitrate and Nitrite Toxicity to Salmonoid Fishes." The Progressive Fish-Culturist 36 (2): 86-89.

Wilde, G. R., and L. J. Paulson. 1989. "Temporal and spatial variation in pelagic fish abundance in Lake Mead determined from echograms." Publications (WR) Paper 35. University of Nevada, Las Vegas.

Wooten, J. W., and J. D. Dodd. 1976. "Growth of Water Hyacinths in Treated Sewage Effluent." Economic Botany 30: 29-37. 
Appendix 1. Rainbowfish species of Papua and their distribution area.

\begin{tabular}{|c|c|c|c|c|c|c|}
\hline \multirow[b]{2}{*}{ No. } & \multirow[b]{2}{*}{ Species } & \multirow[b]{2}{*}{ Common Name } & \multirow[b]{2}{*}{ Distribution } & \multicolumn{3}{|c|}{ Region } \\
\hline & & & & $\begin{array}{l}\text { Northern } \\
\text { New Guinea }\end{array}$ & $\begin{array}{l}\text { Southern } \\
\text { New Guinea }\end{array}$ & $\begin{array}{l}\text { Western New } \\
\text { Guinea (Bird's } \\
\text { Head region) }\end{array}$ \\
\hline 1 & 2 & 3 & 4 & 5 & 6 & 7 \\
\hline 1 & Chilatherina alleni & Allen's Rainbowfish & $\begin{array}{l}\text { Aiborei River of the Siriwo drainage, situated in the Derewo River } \\
\text { Basin, southeast of Cenderawasih Bay in northern West Papua. }\end{array}$ & $\mathrm{x}$ & & \\
\hline 2 & C. bleheri & Bleher's Rainbowfish & Lake Holmes (Danau Bira), lower Mamberamo system. & $\mathrm{x}$ & & \\
\hline 3 & C. crassispinosa* & Silver Rainbowfish & $\begin{array}{l}\text { Widespread in northern New Guinea, including the Markham, } \\
\text { Gogol, Ramu, Sepik, Pual, and Mamberamo Rivers. }\end{array}$ & $\mathrm{x}$ & & \\
\hline 4 & C. fasciata* & Barred Rainbowfish & $\begin{array}{l}\text { Widespread in northern New Guinea, including the Markham, } \\
\text { Ramu, Sepik, and Mamberamo river systems; has also recently } \\
\text { been discovered on Yapen Island. }\end{array}$ & $x$ & & \\
\hline 5 & C. lorentzi* & Lorentz's Rainbowfish & $\begin{array}{l}\text { Tawarin River on the north coast of Irian Jaya about } 200 \mathrm{~km} \text { west } \\
\text { of Jayapura, and Puive Creek, a tributary of the Pual River near } \\
\text { Vanimo. }\end{array}$ & $x$ & & \\
\hline 6 & C. pricei & Price's Rainbowfish & $\begin{array}{l}\text { The Reifafeif River in Yapen Island, which is situated in } \\
\text { Cenderawasih Bay (formerly Geelvink Bay) off the northern coast } \\
\text { of West Papua. }\end{array}$ & $\mathrm{x}$ & & \\
\hline 7 & C. sentaniensis & Sentani Rainbowfish & $\begin{array}{l}\text { Lake Sentani, which is located some } 10 \text { kilometers west of } \\
\text { Jayapura. }\end{array}$ & $\mathrm{x}$ & & \\
\hline 8 & Glossolepis dorityi & Dority's Rainbowfish & Grime River of northern West Papua. & $x$ & & \\
\hline 9 & G. incisus & Red Rainbowfish & Lake Sentani. & $x$ & & \\
\hline 10 & G. leggeti & Leggett's Rainbowfish & Wapoga River system of northern West Papua. & $\mathrm{x}$ & & \\
\hline 11 & G. multisquamatus & Sepik Rainbowfish & Mamberamo river system in Papua. & $x$ & & \\
\hline 12 & G. pseudoincisus & $\begin{array}{l}\text { Tami River } \\
\text { Rainbowfish }\end{array}$ & Tami River, Enfote Lake, Yaniruk Lake. & $\mathrm{x}$ & & \\
\hline
\end{tabular}




\begin{tabular}{|c|c|c|c|c|c|c|}
\hline 1 & 2 & 3 & 4 & 5 & 6 & 7 \\
\hline 13 & I. werneri** & $\begin{array}{l}\text { Threadfin } \\
\text { Rainbowfish }\end{array}$ & $\begin{array}{l}\text { Central-southern New Guinea between the Merauke and Fly } \\
\text { Rivers. }\end{array}$ & & $\mathrm{x}$ & \\
\hline 14 & M. affinis* & $\begin{array}{l}\text { North New Guinea } \\
\text { Rainbowfish }\end{array}$ & $\begin{array}{l}\text { North of the Central Dividing Range; the distribution extends } \\
\text { from the vicinity of Lae, Papua New Guiea, and westward into } \\
\text { Papua as far as Nabire. }\end{array}$ & $x$ & & \\
\hline 15 & M. ajamaruensis & $\begin{array}{l}\text { Ajamaru Lakes } \\
\text { Rainbowfish }\end{array}$ & $\begin{array}{l}\text { The Ayamaru Lakes, situated near the centre of the Bird's Head } \\
\text { Peninsula, and Kaliwensi River, about } 5 \mathrm{~km} \text { west of the } \\
\text { Ayamaru Lakes. }\end{array}$ & & & $\mathrm{X}$ \\
\hline 16 & M. ammeri & - & Gusimawa stream, northern part of Arguni Bay. & & & $\mathrm{X}$ \\
\hline 17 & M. angfa & Yakati Rainbowfish & $\begin{array}{l}\text { Kurumoi Creek, near Lake Kurumoi and about } 12 \mathrm{~km} \text { north of } \\
\text { Yakati Village, and Pondok Creek, which are both in the Yakati } \\
\text { river system of West Papua. }\end{array}$ & & & $x$ \\
\hline 18 & M. arfakensis & Arfak Rainbowfish & Tributaries of the Prafi River system near Manokwari, only. & & & $x$ \\
\hline 19 & M. arguni & $\begin{array}{l}\text { Arguni } \\
\text { Rainbowfish }\end{array}$ & $\begin{array}{l}\text { Egerwara village, Jasu Creek, } 61 \text { km north of Kaimana, District } \\
\text { Arguni Bawah, West Papua. }\end{array}$ & & & $\mathrm{X}$ \\
\hline 20 & M. batanta & $\begin{array}{l}\text { Batanta } \\
\text { Rainbowfish }\end{array}$ & $\begin{array}{l}\text { Batanta island in the Raja Ampat Group, west of the Bird's } \\
\text { Head Peninsula. }\end{array}$ & & & $x$ \\
\hline 21 & M. boesemani & $\begin{array}{l}\text { Boeseman's } \\
\text { Rainbowfish }\end{array}$ & $\begin{array}{l}\text { Found mainly in the Ayamaru Lakes and a few surrounding } \\
\text { tributaries, as well as in Lake Hain and Lake Aitinjo. The } \\
\text { Ayamaru Lakes region is located about } 120 \mathrm{~km} \text { east-southeast } \\
\text { of Sorong, at the headwaters of the Ayamaru River in a } \\
\text { mountainous region of the Bird's Head Peninsula. }\end{array}$ & & & $x$ \\
\hline 22 & M. catherinae & $\begin{array}{l}\text { Waigeo } \\
\text { Rainbowfish }\end{array}$ & $\begin{array}{l}\text { Waigeo and Batanta Islands in the Raja Ampat Group that lie } \\
\text { immediately west of the Bird's Head Peninsula. }\end{array}$ & & & $x$ \\
\hline 23 & M. corona & $\begin{array}{l}\text { Corona } \\
\text { Rainbowfish }\end{array}$ & $\begin{array}{l}\text { Upper Sermowai River on the north coast of West Papua, } \\
\text { about } 75 \text { kilometers west of Jayapura. }\end{array}$ & $\mathrm{X}$ & & \\
\hline 24 & M. fasinensis & - & Tributary of Kladuk River, Fasin creek, northwest Teminabuan. & & & $x$ \\
\hline
\end{tabular}




\begin{tabular}{|c|c|c|c|c|c|c|}
\hline 1 & 2 & 3 & 4 & 5 & 6 & 7 \\
\hline 25 & M. fredericki & $\begin{array}{l}\text { Sorong } \\
\text { Rainbowfish }\end{array}$ & $\begin{array}{l}\text { Samson river system and streams near Sorong on the western } \\
\text { portion of the Bird's Head Peninsula. }\end{array}$ & & & $\mathrm{x}$ \\
\hline 26 & M. goldiei* & $\begin{array}{l}\text { Goldie River } \\
\text { Rainbowfish }\end{array}$ & $\begin{array}{l}\text { South of the Central Dividing Range, extending from Port Moresby } \\
\text { in Papua New Guinea to Etna Bay in Papua, as well as the Aru } \\
\text { Islands. }\end{array}$ & & & $\mathrm{x}$ \\
\hline 27 & M. irianjaya & $\begin{array}{l}\text { Irian Jaya } \\
\text { Rainbowfish }\end{array}$ & $\begin{array}{l}\text { Widely distributed in southerly-flowing river systems of the Bird's } \\
\text { Head Peninsula, as well as southern Bomberai Peninsula. }\end{array}$ & & & $\mathrm{X}$ \\
\hline 28 & M. japenensis & Yapen Rainbowfish & $\begin{array}{l}\text { Yapen Island, which is situated in the gulf (Teluk Sarera) on the } \\
\text { north coast of West Papua. }\end{array}$ & $\mathrm{X}$ & & \\
\hline 29 & M. kamaka & $\begin{array}{l}\text { Kamaka } \\
\text { Rainbowfish }\end{array}$ & $\begin{array}{l}\text { Lake Kamakawaiar and several smaller ones just inland from Triton } \\
\text { Bay, which is situated on the southern coast of West Papua, } \\
\text { immediately east of the Bomberai Peninsula. }\end{array}$ & & & $\mathrm{X}$ \\
\hline 30 & M. kokasensis & - & Small stream near Kokas Village on the north Fak Fak Peninsula. & & & $\mathrm{x}$ \\
\hline 31 & M. lakamora & $\begin{array}{l}\text { Lakamora } \\
\text { Rainbowfish }\end{array}$ & $\begin{array}{l}\text { Lake Lakamora and Lake Aiwaso, which are also inland from Triton } \\
\text { Bay. }\end{array}$ & & & $\mathrm{x}$ \\
\hline 32 & M. mairasi & - & $\begin{array}{l}\text { Lake Furnusu, which lies approximately } 15 \mathrm{~km} \text { northeast of } \\
\text { Kaimana, West Papua. }\end{array}$ & & & $\mathrm{X}$ \\
\hline 33 & M. maylandi & $\begin{array}{l}\text { Mayland's } \\
\text { Rainbowfish }\end{array}$ & $\begin{array}{l}\text { Known only from a small creek about 2-3 km from Lake Holmes, } \\
\text { Mamberamo. }\end{array}$ & $\mathrm{X}$ & & \\
\hline 34 & M. misoolensis & $\begin{array}{l}\text { Misool } \\
\text { Rainbowfish }\end{array}$ & $\begin{array}{l}\text { Tama River in Misool Island, which is part of the Raja Ampat } \\
\text { Group. }\end{array}$ & & & $\mathrm{x}$ \\
\hline 35 & M. ogilbyi & $\begin{array}{l}\text { Ogilby's } \\
\text { Rainbowfish }\end{array}$ & Lower Lorentz River and Timika Region. & & $X$ & \\
\hline 36 & M. parva & $\begin{array}{l}\text { Lake Kurumoi } \\
\text { Rainbowfish }\end{array}$ & $\begin{array}{l}\text { Known only from Lake Kurumoi in the middle of the narrow } \\
\text { isthmus that connects the Bird's Head Peninsula to the remainder } \\
\text { of New Guinea. The lake is within the Yakati River watershed. }\end{array}$ & & & $\mathrm{X}$ \\
\hline
\end{tabular}


Appendix 1. Rainbowfish species of Papua and their distribution area (continued).

\begin{tabular}{|c|c|c|c|c|c|c|}
\hline 1 & 2 & 3 & 4 & 5 & 6 & 7 \\
\hline 37 & M. pierucciae & $\begin{array}{l}\text { Pierucci's } \\
\text { Rainbowfish }\end{array}$ & Werfyang Creek and Lake Kamakawaiar. & & & $\mathrm{X}$ \\
\hline 38 & M. praecox & Dwarf Rainbowfish & Mamberamo and Wapoga river systems. & $x$ & & \\
\hline 39 & M. rubripinnis & $\begin{array}{l}\text { Red-finned } \\
\text { Rainbowfish }\end{array}$ & Wapoga river system of northern West Papua. & $x$ & & \\
\hline 40 & M. salawati & - & $\begin{array}{l}\text { Doktor Creek, a stream 5-10 m wide, in the vicinity of } \\
\text { Waipule village on the northwestern part of Salawati Island. }\end{array}$ & & & $\mathrm{X}$ \\
\hline 41 & M. rubrostriata** & $\begin{array}{l}\text { Red-striped } \\
\text { Rainbowfish }\end{array}$ & $\begin{array}{l}\text { South of the Central Dividing Range, on the Aramia River } \\
\text { (near the Fly River) of Papua New Guinea and Etna Bay, } \\
\text { central Papua. }\end{array}$ & & & $\mathrm{x}$ \\
\hline 42 & M. synergos & $\begin{array}{l}\text { Batanta Island } \\
\text { Rainbowfish }\end{array}$ & Batanta Island, west of the Bird's Head Peninsula. & & & $x$ \\
\hline 43 & M. urisa & Urisa Rainbowfish & $\begin{array}{l}\text { Sewiki Lake, } 6 \text { km SE of Urisa Village, } 44 \text { km north of } \\
\text { Kaimana }\end{array}$ & & & $\mathrm{X}$ \\
\hline 44 & M. vanheurni & $\begin{array}{l}\text { Van Heurn's } \\
\text { Rainbowfish }\end{array}$ & $\begin{array}{l}\text { The Taritatu River and Doorman River (which is a tributary } \\
\text { of theTaritatu). }\end{array}$ & $x$ & & \\
\hline 45 & M. veoliae & Veolia Rainbowfish & $\begin{array}{l}\text { Gebiasi Creek, } 22 \mathrm{~km} \text { north of Kaimana and } 14 \mathrm{~km} \text { south of } \\
\text { Wanoma Village. }\end{array}$ & & & $x$ \\
\hline 46 & M. wanoma & $\begin{array}{l}\text { Wanoma } \\
\text { Rainbowfish }\end{array}$ & $\begin{array}{l}\text { Wermura Creek, } 20 \mathrm{~km} \text { north of Kaimana and } 16 \mathrm{~km} \text { south } \\
\text { of Wanoma Village. }\end{array}$ & & & $x$ \\
\hline 47 & $\begin{array}{l}\text { Pelangia } \\
\text { mbutaensis }\end{array}$ & $\begin{array}{l}\text { Lake Mbuta } \\
\text { Rainbowfish }\end{array}$ & Mbuta Basin, Bintuni Bay. & & & $x$ \\
\hline \multicolumn{2}{|c|}{ Total } & & & 19 & 2 & 26 \\
\hline
\end{tabular}

*New Guinean species.

**New Guinean and Australian species.

Sources: Allen and Hadiaty 2011; Kadarusman et al. 2010, 2011, 2012; Tappin 2010; Allen and Unmack 2008; Allen et al. 2008; Mack and Alonso 2000; Richards and Suryadi 2002; Allen and Renyaan 1995, 1996a, 1996b, 1998a, 1998b, $2000 a, 2000 b ;$ Allen $1991,1998$. 
Appendix 2. Description of research locations.

\begin{tabular}{|c|c|c|c|}
\hline Zone/Group & Location & Description & Sampling sites \\
\hline 1 & 2 & 3 & 4 \\
\hline $1 / 1$ & AW (Waena) & $\begin{array}{l}\text { - There are two administrative villages in the area, } \\
\text { Waena and Yabansai. Waena has an area of 14,024 ha } \\
\text { and population of } 15,738, \text { while Yabansai has an area } \\
\text { and population of } 12.5 \text { ha } \pm 13,000 \text {. } \\
\text { - It is located adjacent to a major provincial road } \\
\text { connecting the districts of Jayapura Municipality to } \\
\text { those of Sentani Regency. } \\
\text { - The biggest state university in Papua, Cenderawasih } \\
\text { University (UNCEN), is located in the area, resulting in } \\
\text { population flux throughout the year. } \\
\text { Mostly of the houses in the area are modern and } \\
\text { located away from the lake. However, domestic waste, } \\
\text { both organic and inorganic, is drained into the lake by } \\
\text { rain. } \\
\text { Waste is often dumped into the creeks, and then } \\
\text { washed or drained into the lake. } \\
\text { Deforestation occurs in the area, causing habitat } \\
\text { alteration in the terrestrial area and consequently } \\
\text { impacting the lake's ecosystem by increasing turbidity } \\
\text { and sedimentation. }\end{array}$ & $\begin{array}{l}\text { I. Located } 2^{\circ} 36.032^{\prime} \mathrm{S}, 140^{\circ} 37.575^{\prime} \mathrm{E} \text {, } \\
\text { around the mouth of a creek; mostly silt } \\
\text { and sand substrate; water was turbid; } \\
\text { large amount of inorganic and organic } \\
\text { waste was found in the site; dense } \\
\text { Hydrilla verticilata; small number of } \\
\text { houses near the lake, using its water for } \\
\text { daily needs and fishing. Fish sampling was } \\
\text { conducted at a depth of less than } 130 \mathrm{~cm} \text {. } \\
\text { II. Located } 2^{\circ} 35.837^{\prime} \mathrm{S}, 140^{\circ} 37.391^{\prime} \mathrm{E} \text {, } \\
\text { around } 272 \mathrm{~m} \text { NE of sampling site I; } \\
\text { sampling took place near a house with } \\
\text { sand, gravel, and cobble substrates; dense } \\
\text { Hydrilla verticillata. Fish sampling was } \\
\text { conducted at a depth of less than } 150 \mathrm{~cm} \text {. } \\
\text { III. Located } 2^{\circ} 35.895^{\prime} \mathrm{S}, 140^{\circ} 37.170^{\prime} \mathrm{E} \text {, } \\
\text { around } 414 \text { m NE of sampling site I; sand, } \\
\text { gravel, and cobble substrates; Hydrilla } \\
\text { verticillata, and some Eichhornia } \\
\text { crassipes. Fish sampling was conducted at } \\
\text { a depth of around and less than } 100 \mathrm{~cm} \text {. } \\
\text { By } 2011 \text {, the number of houses had } \\
\text { increased, causing sedimentation and } \\
\text { increased turbidity. }\end{array}$ \\
\hline
\end{tabular}


Appendix 2. Description of research locations (continued).

\begin{tabular}{|c|c|c|c|}
\hline 1 & 2 & 3 & 4 \\
\hline$I / 1$ & AY (Yoka) & $\begin{array}{l}\text { - It is a village in the eastern part of the lake, adjacent to } \\
\text { a road connecting Jayapura to a number of villages } \\
\text { south of Lake Sentani. } \\
\text { - Population numbered } 2000 \text { within a } 10 \text { ha } \\
\text { administrative area. } \\
\text { - Human impact includes organic and inorganic domestic } \\
\text { waste and use of the shoreline as a landfill by } \\
\text { restaurants and governmental buildings. }\end{array}$ & $\begin{array}{l}\text { I. Located } 2^{\circ} 36.560^{\prime} \mathrm{S} 140^{\circ} 37.306^{\prime} \mathrm{E} \text {, near } \\
\text { houses on the edge of the village; gravel } \\
\text { and cobble substrates; Hydrilla verticillata } \\
\text { present only in some spots. Fish sampling } \\
\text { was conducted at a depth of less than } 60 \\
\mathrm{~cm} \text {. } \\
\text { II. Located } 2^{\circ} 36.433^{\prime} \mathrm{S} 140^{\circ} 37.399^{\prime} \mathrm{E} \text {; around } \\
302 \mathrm{~m} \mathrm{SW} \text { of sampling site I; only gravel } \\
\text { substrate; Hydrilla verticillata was found in } \\
\text { almost the entire area. Fish sampling was } \\
\text { conducted at a depth of around and less } \\
\text { than } 150 \mathrm{~cm} \text {. } \\
\text { III. Located } 2^{\circ} 36.409^{\prime} \mathrm{S}, 140^{\circ} 37.484^{\prime} \mathrm{E} \text {, around } \\
458 \mathrm{~m} \mathrm{SW} \text { of sampling site I; silt and sand } \\
\text { substrates; Hydrilla verticillata and } \\
\text { Vallisneria americana were abundant in the } \\
\text { area. Fish sampling was conducted at a } \\
\text { depth of around } 50 \mathrm{~cm} \text { and lower. }\end{array}$ \\
\hline $1 / 2$ & $\begin{array}{l}\text { AJ (Jembatan } \\
\text { 2) }\end{array}$ & $\begin{array}{l}\text { Located along a provincial major road connecting } \\
\text { districts in Jayapura Municipality and Jayapura } \\
\text { Regency. } \\
\text { - Jembatan II Creek, (famous amongst rainbowfish } \\
\text { researchers as Carwash Creek) is found in this } \\
\text { location. } \\
\text { - Small-scale gold mining takes place in the creek's } \\
\text { headwaters, causing turbidity and sedimentation in } \\
\text { the creek and lake. }\end{array}$ & $\begin{array}{l}\text { I. Located } 2^{\circ} 35.433^{\prime} \mathrm{S}, 140^{\circ} 36.977^{\prime} \mathrm{E} \text {, around } \\
\text { the mouth of the creek; water was turbid; } \\
\text { substrates were silt, sand, and gravel; } \\
\text { erosion in the headwaters of the creek } \\
\text { caused sedimentation in the creek's mouth } \\
\text { and some meters into the lake, as well; } \\
\text { vegetation was dominated by Hydrilla } \\
\text { verticillata. Fish sampling was conducted at } \\
\text { a depth of less than } 50 \mathrm{~cm} \text {. }\end{array}$ \\
\hline
\end{tabular}


Appendix 2. Description of research locations (continued).

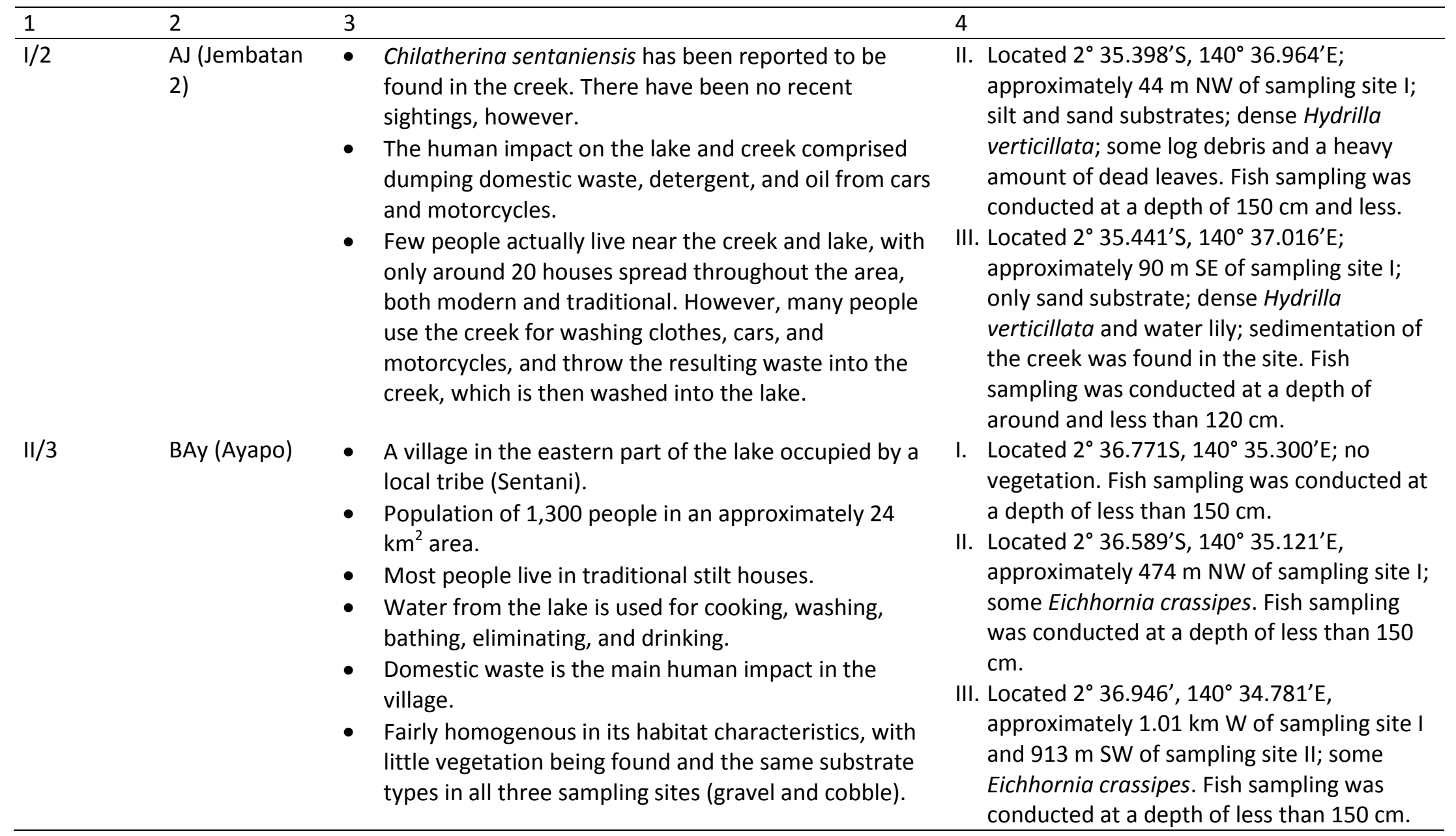


Appendix 2. Description of research locations (continued).

\begin{tabular}{|c|c|c|c|}
\hline 1 & 2 & 3 & 4 \\
\hline $1 \mathrm{II} 3$ & BAs (Asei) & $\begin{array}{l}\text { - It is a small island, less than } 21.6 \mathrm{~km}^{2} \text {, in the eastern } \\
\text { part of the lake, with a population of } 400 \text {. } \\
\text { Lake water is used for daily activities, including } \\
\text { cooking, drinking, washing and bathing, and } \\
\text { eliminating. Therefore, household waste is the main } \\
\text { human impact, in addition to waste from livestock, } \\
\text { specifically pigs. } \\
\text { Gravel and cobble are the main substrates, and } \\
\text { vegetation is not common, only being found in one } \\
\text { sampling site. }\end{array}$ & $\begin{array}{l}\text { I. Located } 2^{\circ} 36.304 \mathrm{~S}, 140^{\circ} 34.798^{\prime} \mathrm{E} \text {. Fish } \\
\text { sampling was conducted at a depth of } 150 \\
\mathrm{~cm} \text { and less. } \\
\text { II. Located } 2^{\circ} 36.312 \mathrm{~S}, 140^{\circ} 34.856^{\prime} \mathrm{E} \text {, } \\
\text { approximately } 107 \mathrm{~m} \mathrm{E} \text { of sampling site I; } \\
\text { small groups of Eichhornia crassipes, which } \\
\text { are distributed by wind. Fish sampling was } \\
\text { conducted at a depth of } 150 \mathrm{~cm} \text { and less. } \\
\text { III. Located } 2^{\circ} 36.265^{\prime} \mathrm{S}, 140^{\circ} 34.859^{\prime} \mathrm{E} \text {, } \\
\text { approximately } 134 \mathrm{~m} \mathrm{NE} \text { of sampling site I } \\
\text { and around } 88 \mathrm{~m} \mathrm{~N} \text { of sampling site II. Fish } \\
\text { sampling was conducted at a depth of } 150 \\
\mathrm{~cm} \text { and less. }\end{array}$ \\
\hline $11 / 3$ & BP (Puay) & $\begin{array}{l}\text { - It is a village of } 523 \text { in the southern part of the lake, } \\
\text { near its only outlet, Djafuri Stream. } \\
\text { - It is also located adjacent to the road connecting the } \\
\text { southern part of the lake to Jayapura. } \\
\text { - Although some inhabitants live in the terrestrial area, } \\
\text { most build their homes on stilts on the shoreline. } \\
\text { - } \text { being lake is used for most activities, with the result } \\
\text { small-scale deforestation from traditional gardens. } \\
\text { Fish are commonly found amidst Eichhornia crassipes } \\
\text { and Metroxylon sagu. }\end{array}$ & $\begin{array}{l}\text { I. Located } 2^{\circ} 40.771 \mathrm{~S}, 140^{\circ} 35.234^{\prime} \mathrm{E} \text {; mud was } \\
\text { the predominant substrate; Eichhornia } \\
\text { crassipes was present. Fish sampling was } \\
\text { conducted at a depth of less than } 100 \mathrm{~cm} \text {. } \\
\text { II. Located } 2^{\circ} 40.708 \mathrm{~S}, 140^{\circ} 35.153 \mathrm{E} \text {, } \\
\text { approximately } 190 \mathrm{~m} \mathrm{NW} \text { of sampling site I; } \\
\text { silt and sand substrates; dense grass along } \\
\text { the shoreline. Fish sampling was conducted } \\
\text { at a depth of less than } 100 \mathrm{~cm} \text {. } \\
\text { III. Located } 2^{\circ} 40.433^{\prime} \mathrm{S}, 140^{\circ} 35.281^{\prime} \mathrm{E} \text {, } \\
\text { approximately } 635 \mathrm{~m} \mathrm{~N} \text { of sampling site I } \\
\text { and around } 564 \mathrm{~m} \mathrm{NE} \text { of sampling site II; } \\
\text { were sand and gravel substrates; dense } \\
\text { grass. Fish sampling was conducted at a }\end{array}$ \\
\hline
\end{tabular}


Appendix 2. Description of research locations (continued).

\begin{tabular}{|c|c|c|c|c|c|}
\hline 1 & 2 & 3 & & 4 & \\
\hline $11 / 3$ & BP (Puay) & & & & depth of less than $100 \mathrm{~cm}$. \\
\hline $\mathrm{III} / 3$ & CY (Yakonde) & & $\begin{array}{l}\text { It is a village in the western part of the lake, with a } \\
\text { population of } 400 \text { in a } 2,658 \text { ha area. } \\
\text { Lake water is used for bathing, cooking, drinking, } \\
\text { fishing, and eliminating waste, although modern } \\
\text { toilets are available in the terrestrial area. Livestock } \\
\text { can also be found around locals' houses, along with } \\
\text { their dung in the water. } \\
\text { Inorganic waste is less common than organic waste. } \\
\text { There has been an increasing prevalence of caged fish } \\
\text { farms, as observed during the three years of the } \\
\text { survey. } \\
\text { The Red Rainbowfish is abundant in this location, } \\
\text { especially in gravel, cobble, and boulder substrates. }\end{array}$ & I. & $\begin{array}{l}\text { Located } 2^{\circ} 34.426^{\prime} \mathrm{S}, 140^{\circ} 23.750^{\prime} \mathrm{E} \text {; gravel } \\
\text { and cobble substrates; abundant Hydrilla } \\
\text { verticillata. Fish sampling was conducted at } \\
\text { a depth of less than } 2 \mathrm{~m} \text {. } \\
\text { Located } 2^{\circ} 34.283^{\prime} \mathrm{S}, 140^{\circ} 23.837^{\prime} \mathrm{E} \text {, } \\
\text { approximately } 311 \mathrm{~m} \text { NE of sampling site I; } \\
\text { sand and gravel substrates; Hydrilla } \\
\text { verticillata was the only vegetation. Fish } \\
\text { sampling was conducted at a depth of less } \\
\text { than } 2 \mathrm{~m} \text {. } \\
\text { Located } 2^{\circ} 34.291^{\prime} \mathrm{S}, 140^{\circ} 23.873^{\prime} \mathrm{E} \text {, } \\
\text { approximately } 339 \mathrm{~m} \text { NE of sampling site I; } \\
\text { gravel, cobble, and boulder substrates; } \\
\text { some Hydrilla verticillata. Fish sampling was } \\
\text { conducted at a depth of less than } 2 \text { m. }\end{array}$ \\
\hline $1 \mathrm{II} / 3$ & CR (Rimi) & & $\begin{array}{l}\text { Located in the southern part of the lake, between BAy } \\
\text { and BP, with less than five people in each sampling } \\
\text { site. } \\
\text { Although activities based on the lake include cooking, } \\
\text { drinking, fishing, bathing, and eliminating, the impact } \\
\text { of human activities is lower here than in other } \\
\text { locations, because of the small population. } \\
\text { Only some deforestation occurs for small-scale } \\
\text { traditional gardens. }\end{array}$ & I. & $\begin{array}{l}\text { Located } 2^{\circ} 39.049^{\prime} \mathrm{S}, 140^{\circ} 35.440^{\prime} \mathrm{E} \text {, near a } \\
\text { stilt house; silt and sand substrates; dense } \\
\text { grass near the shoreline. Fish sampling was } \\
\text { conducted at a depth of around } 150 \mathrm{~cm} \text {. } \\
\text { Located } 2^{\circ} 39.168^{\prime} \mathrm{S}, 140^{\circ} 35.294^{\prime} \mathrm{E} \text {, } \\
\text { approximately } 350 \mathrm{~m} \mathrm{SW} \text { of sampling site I; } \\
\text { silt and sand substrates; small number of } \\
\text { Metroxylon sagu, grass, and trees. Fish } \\
\text { sampling was conducted at a depth of } \\
\text { around } 150 \mathrm{~cm} \text {. } \\
\text { Located } 2^{\circ} 38.719^{\prime} \mathrm{S}, 140^{\circ} 35.399^{\prime} \mathrm{E} \text {, }\end{array}$ \\
\hline
\end{tabular}


Appendix 2. Description of research locations (continued).

\begin{tabular}{|c|c|c|c|}
\hline 1 & 2 & 3 & 4 \\
\hline $\mathrm{III} / 3$ & CR (Rimi) & & $\begin{array}{l}\text { approximately } 617 \mathrm{~m} \mathrm{~N} \text { of sampling site I; } \\
\text { silt and sand substrates; no vegetation. Fish } \\
\text { sampling was conducted at a depth of } \\
\text { around } 150 \mathrm{~cm} \text {. }\end{array}$ \\
\hline III/3 & CK (Kanale) & $\begin{array}{l}\text { Kanale is an isolated area in the south of the lake, } \\
\text { between BAy and BP, with almost no human } \\
\text { population. } \\
\text { Two houses can be found in the area, but people } \\
\text { rarely stay in them. } \\
\text { As there is no water vegetation, the Red Rainbowfish } \\
\text { is only found near the shoreline, amongst Metroxylon } \\
\text { sagu and its roots, the roots of trees, and dense beds } \\
\text { of grass. }\end{array}$ & $\begin{array}{l}\text { I. Located } 2^{\circ} 39.144 \mathrm{~S}, 140^{\circ} 36.234^{\prime} \mathrm{E} \text {, near a } \\
\text { house with no residents; sand and gravel } \\
\text { substrates. Fish sampling was conducted at } \\
\text { a depth of less than } 2 \mathrm{~m} \text {. } \\
\text { II. Located } 2^{\circ} 38.936^{\prime} \mathrm{S}, 140^{\circ} 36.328^{\prime} \mathrm{E} \text {, } \\
\text { approximately } 400 \mathrm{~m} \mathrm{~N} \text { of sampling site I. } \\
\text { Fish sampling was conducted at a depth of } \\
\text { less than } 1 \mathrm{~m} \text {. } \\
\text { III. Located } 2^{\circ} 38.794^{\prime} \mathrm{S}, 140^{\circ} 36.359^{\prime} \mathrm{E} \text {, } \\
\text { approximately } 700 \mathrm{~m} \mathrm{~N} \text { of sampling site I; } \\
\text { gravel substrate. Fish sampling was } \\
\text { conducted at a depth of less than } 2 \mathrm{~m} \text {. }\end{array}$ \\
\hline
\end{tabular}


Appendix 3.1. Fish sampling sites in Lake Sentani. Zone I/Group 1: Waena (AW); (a) sampling site 1 , (b) sampling site 2 , and (c) sampling site 3 .

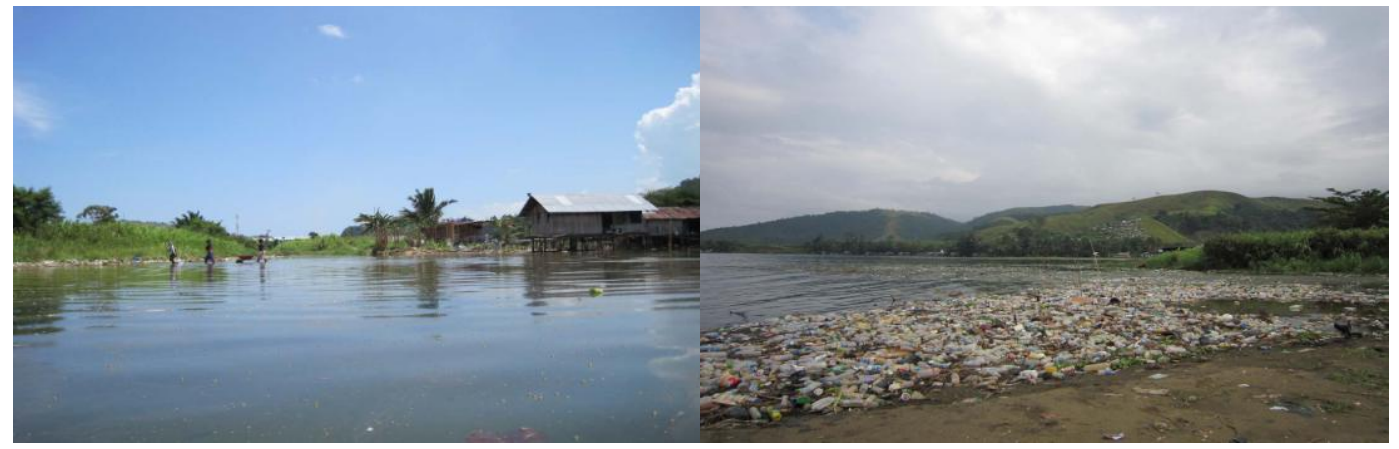

(a)

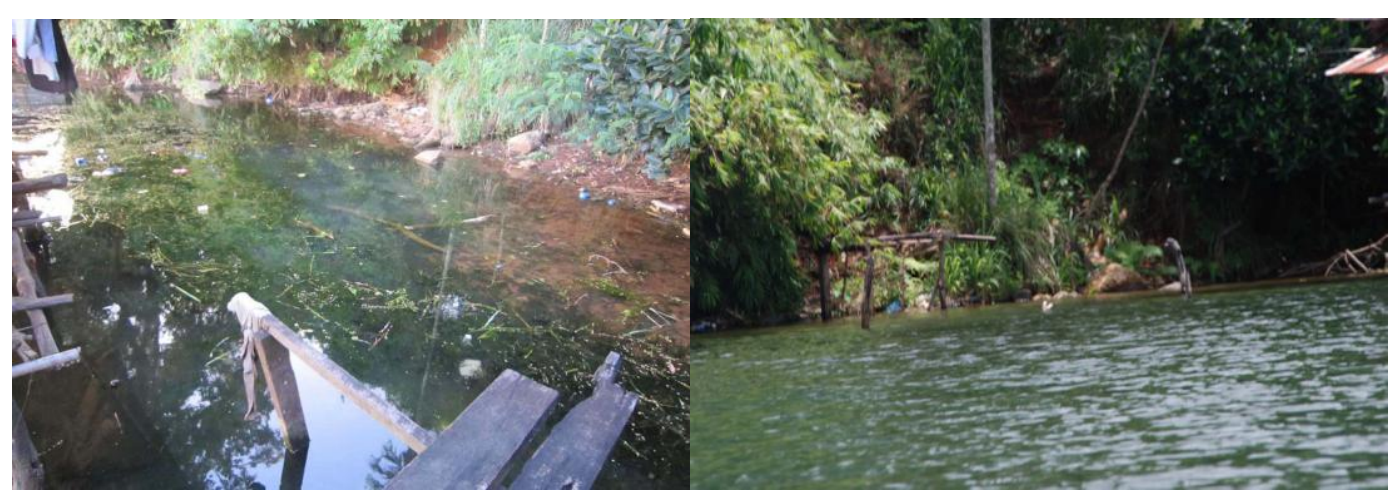

(b)

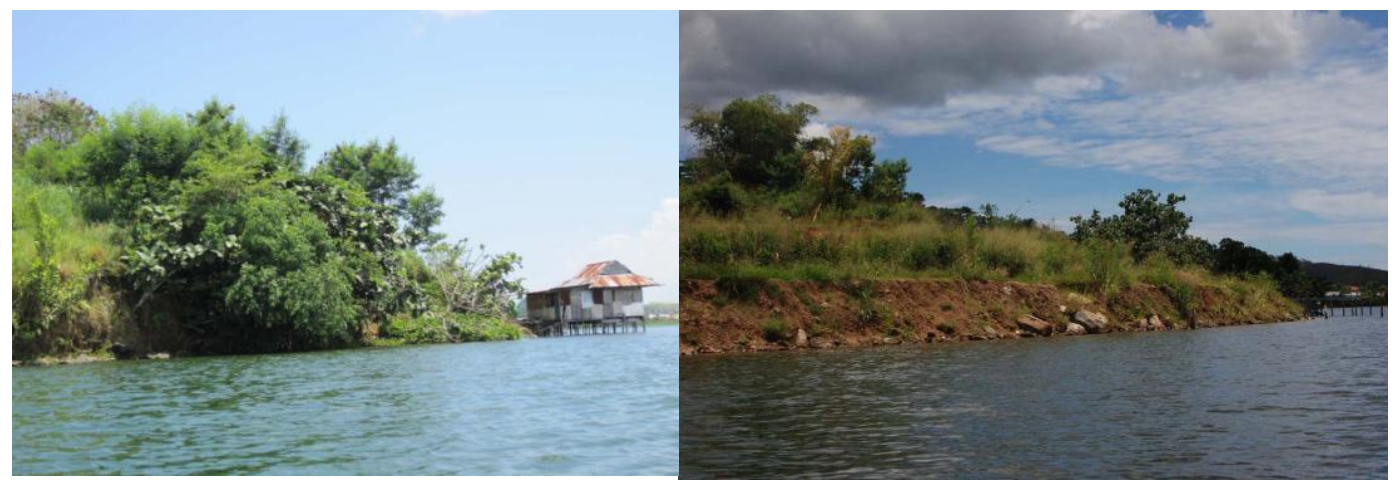

(c) 
Appendix 3.2. Fish sampling sites in Lake Sentani. Zone I/Group 1: Yoka (AY); (a) sampling site 1, (b) sampling site 2, and (c) sampling site 3 .

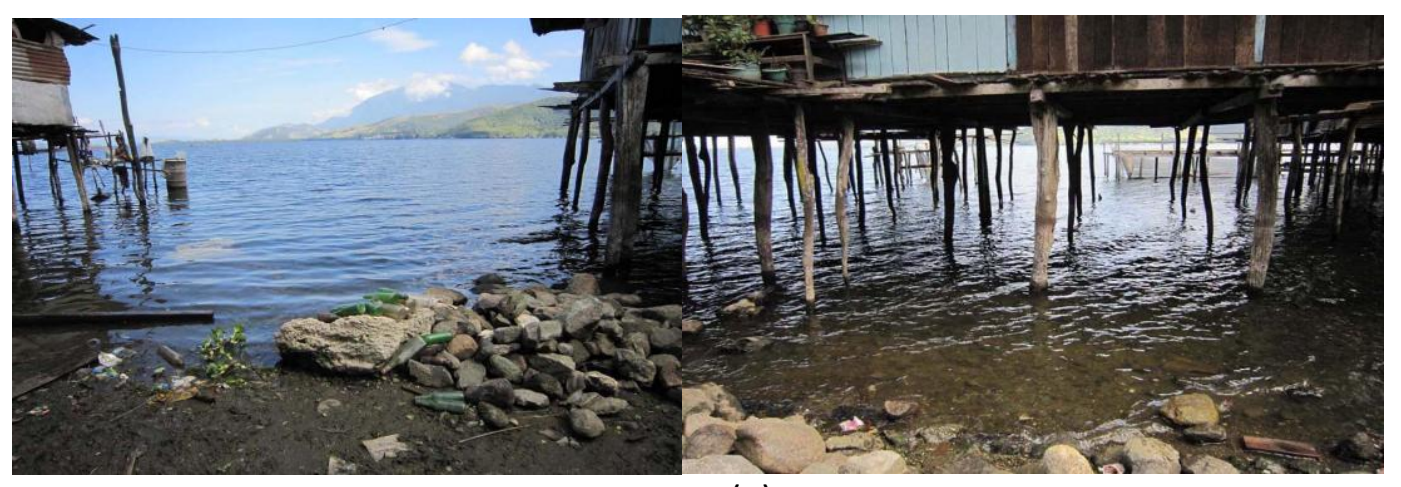

(a)

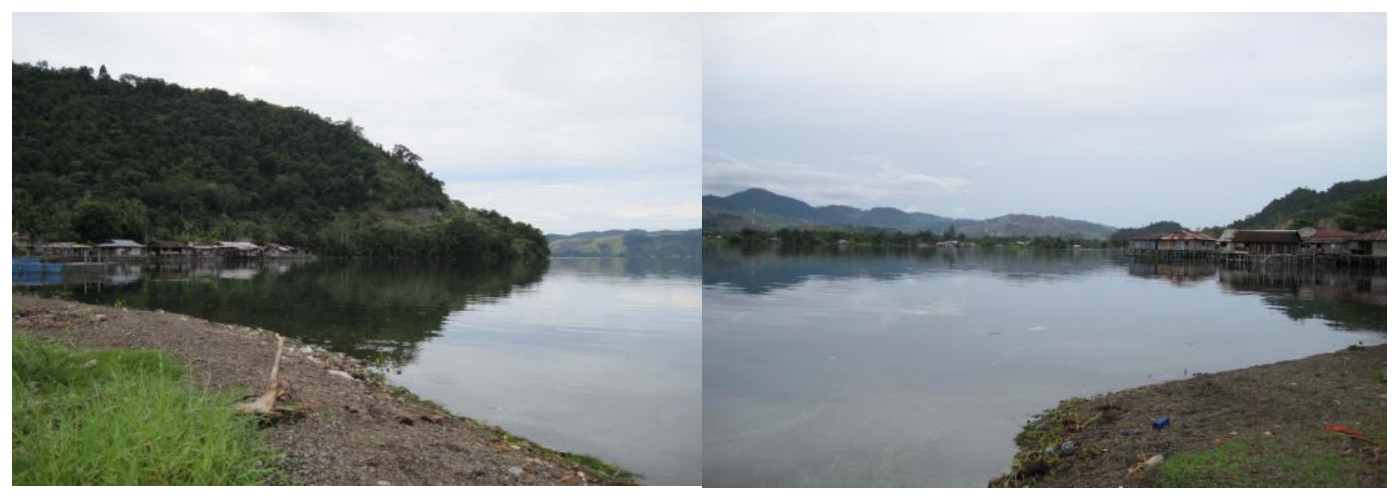

(b)

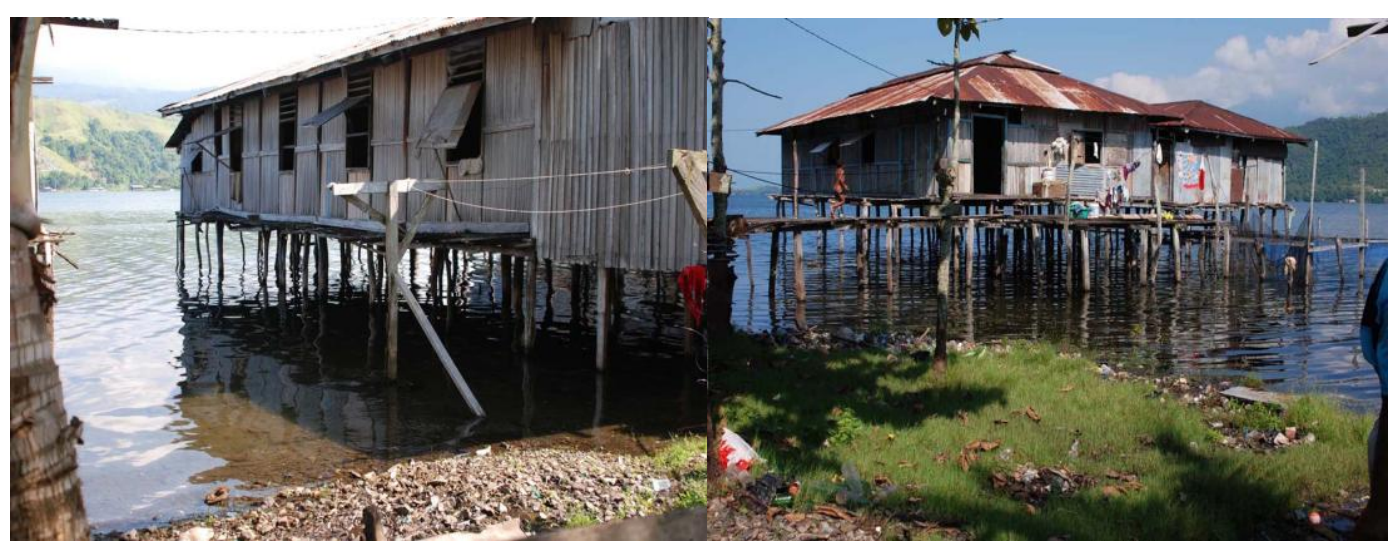

(c) 
Appendix 3.3. Fish sampling sites in Lake Sentani. Zone I/Group 2: Jembatan II (AJ); (a) sampling site 1, (b) sampling site 2 , and (c) sampling site 3.

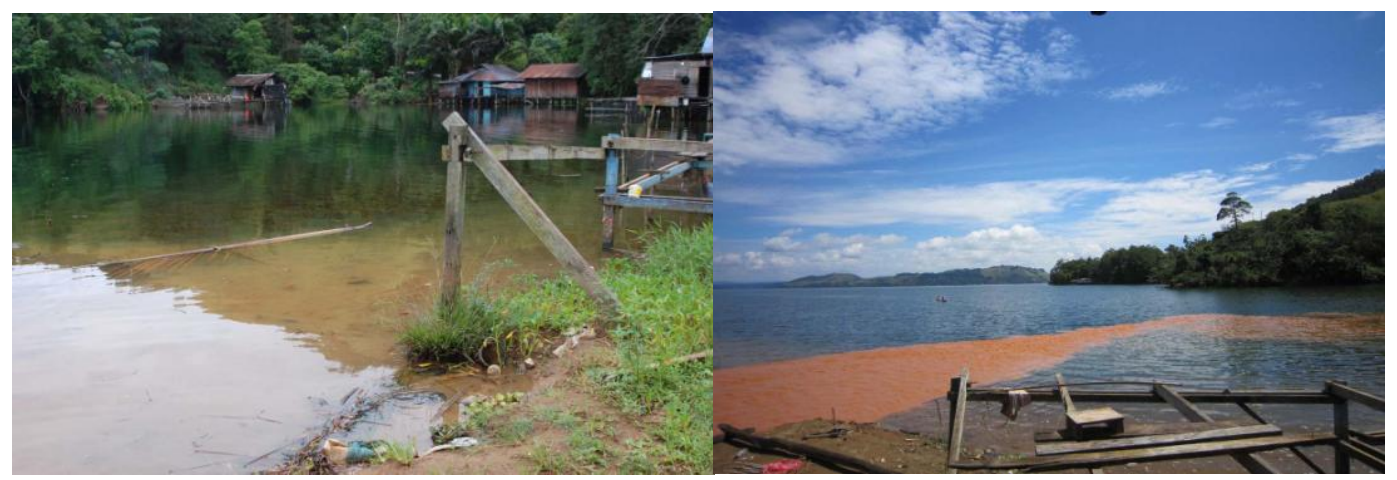

(a)

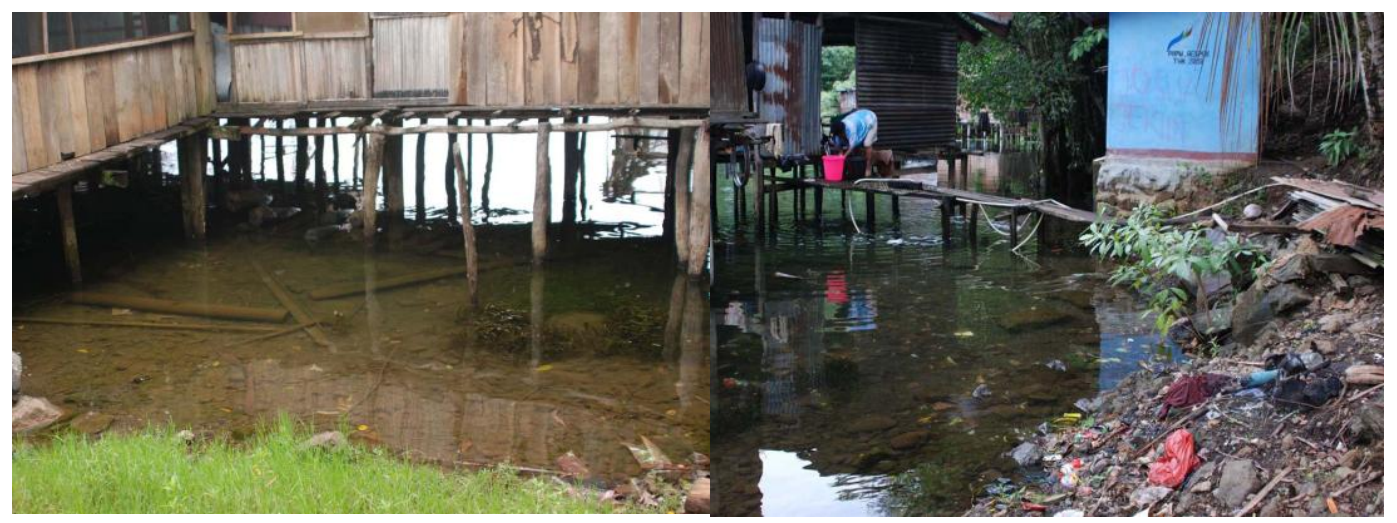

(b)

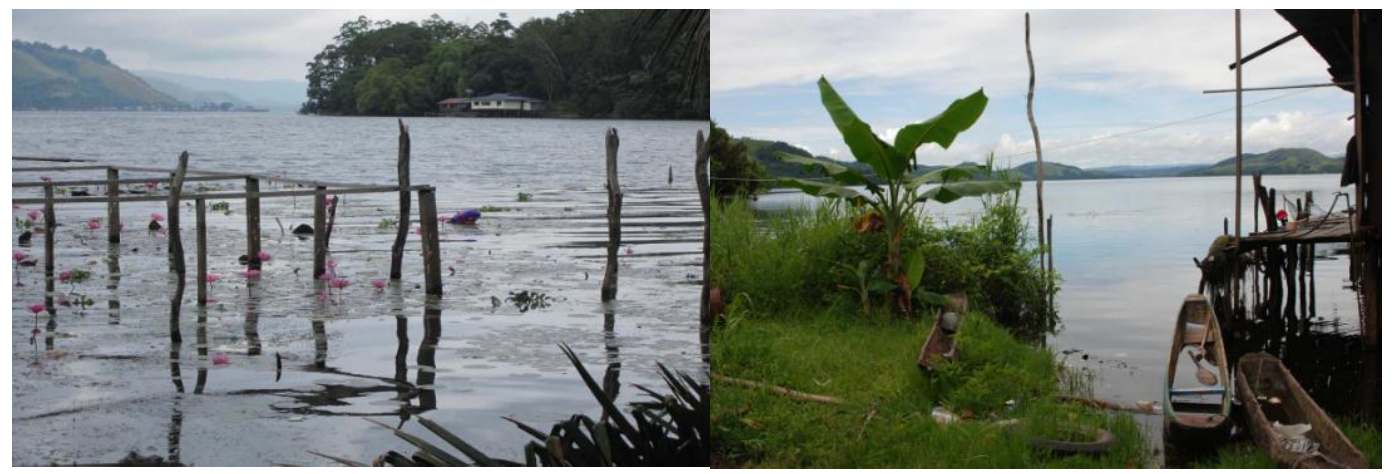

(c) 
Appendix 3.4. Fish sampling sites in Lake Sentani. Zone II/Group 3: Ayapo (BAy); (a) sampling site 1, (b) sampling site 2 , and (c) sampling site 3 .

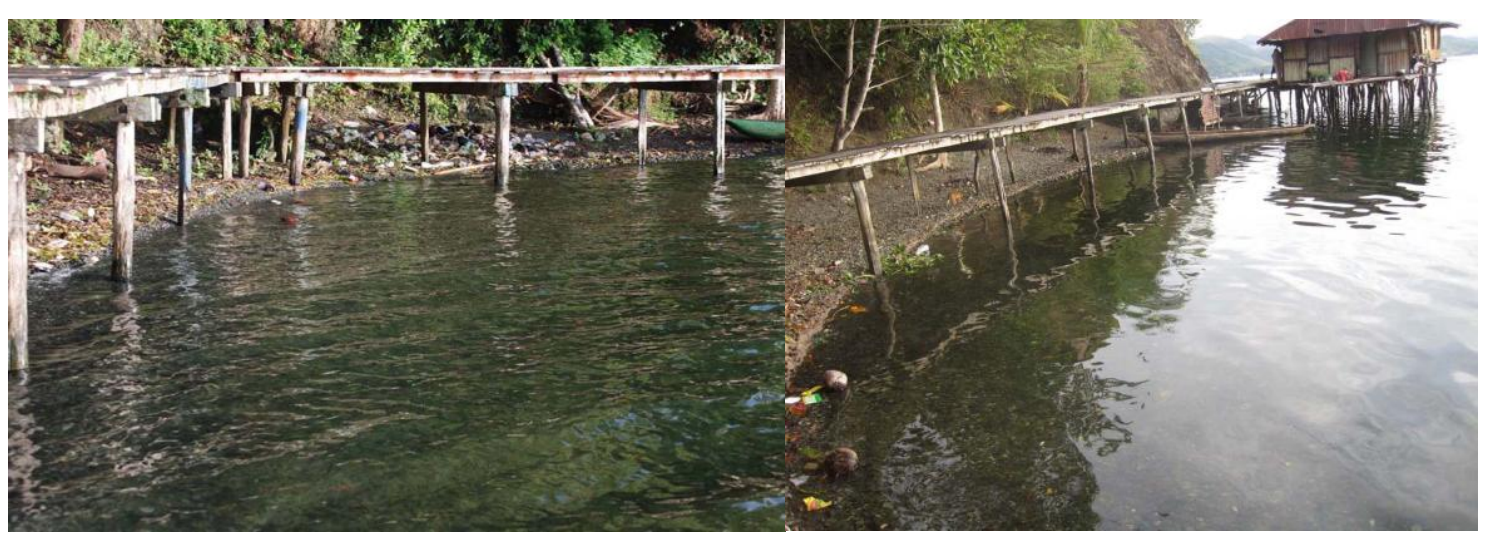

(a)

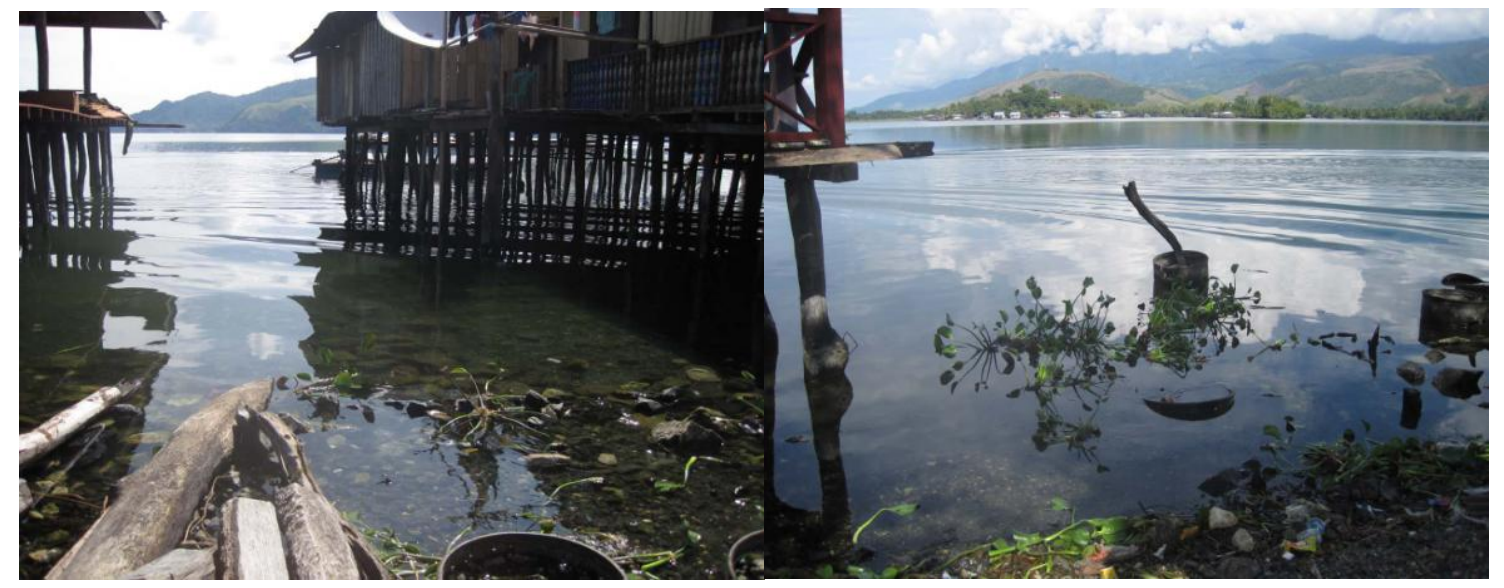

(b)

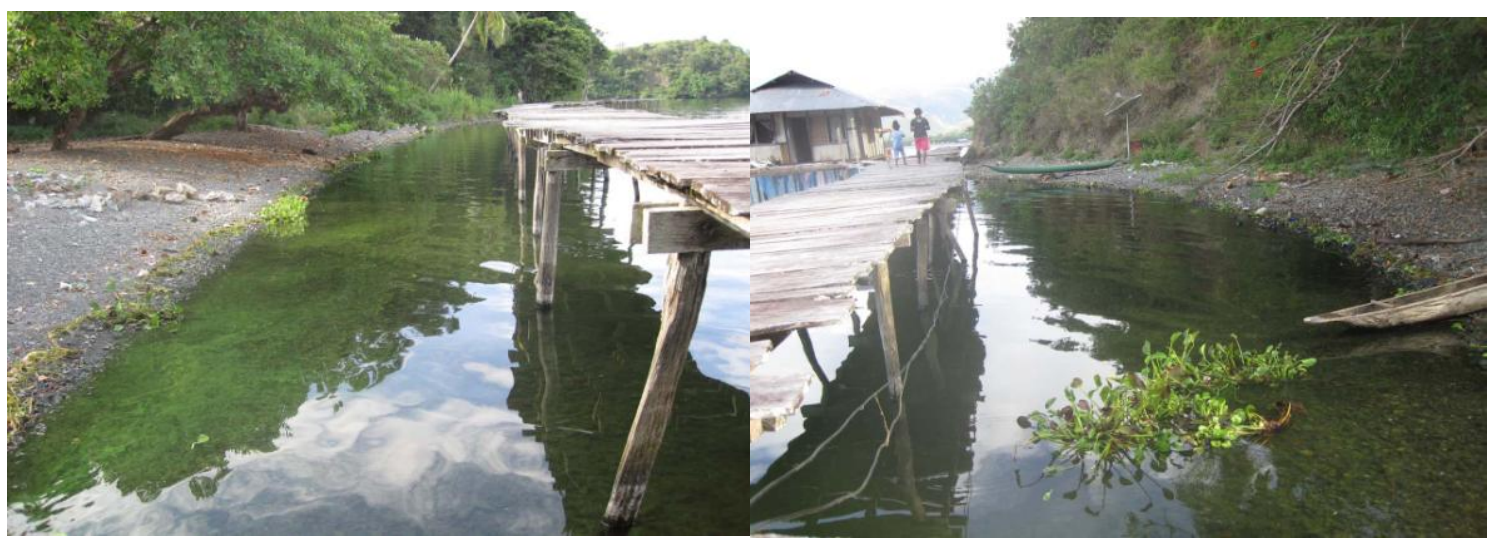

(c) 
Appendix 3.5. Fish sampling sites in Lake Sentani. Zone II/Group 3: Asei (BAs); (a) sampling site 1, (b) sampling site 2 , and (c) sampling site 3 .

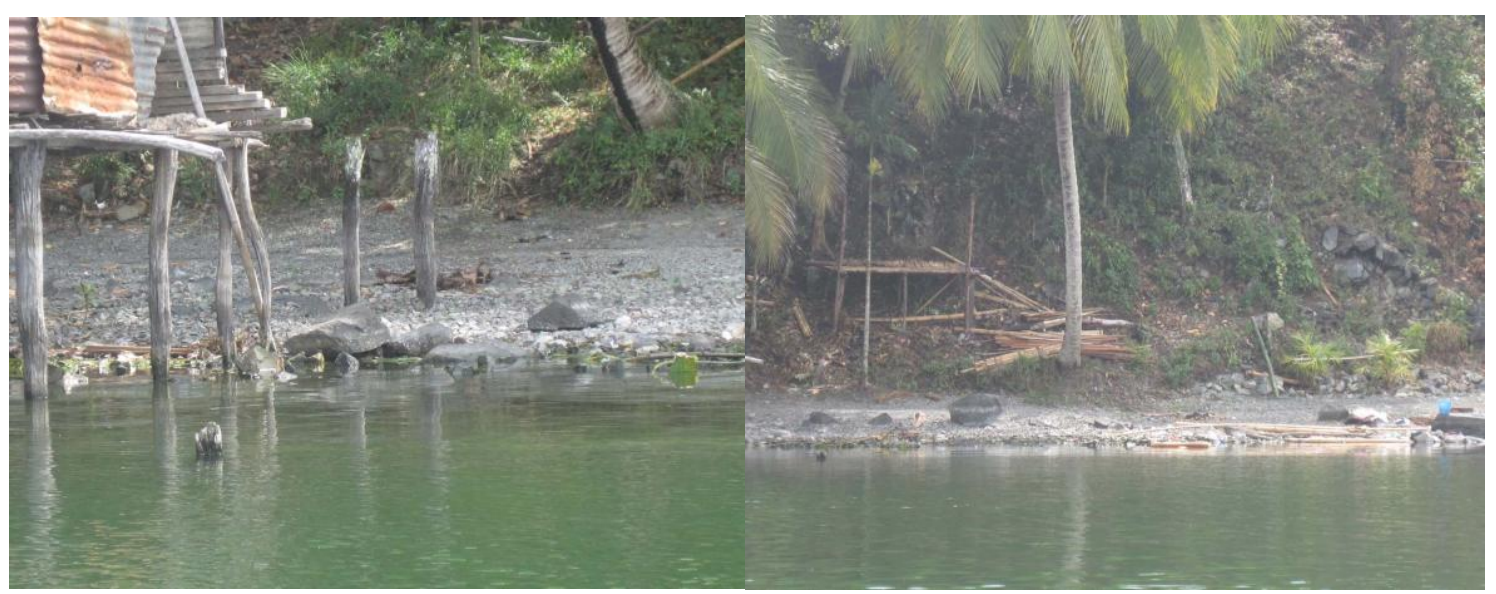

(a)

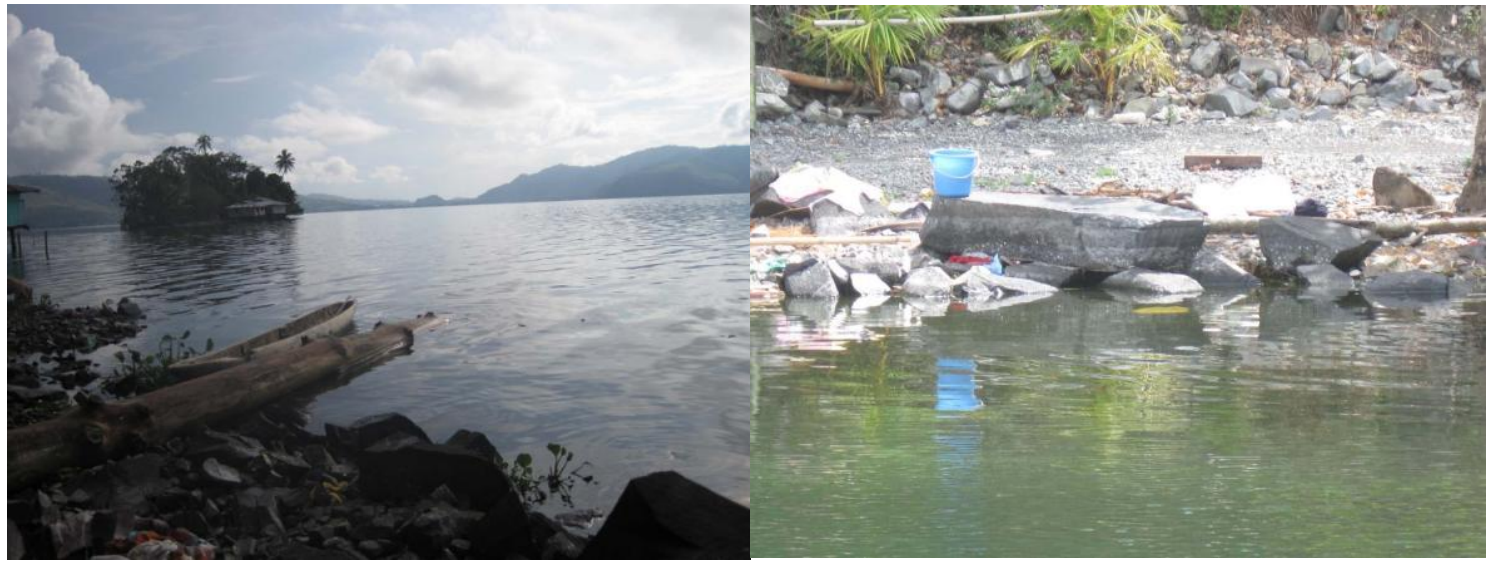

(b)

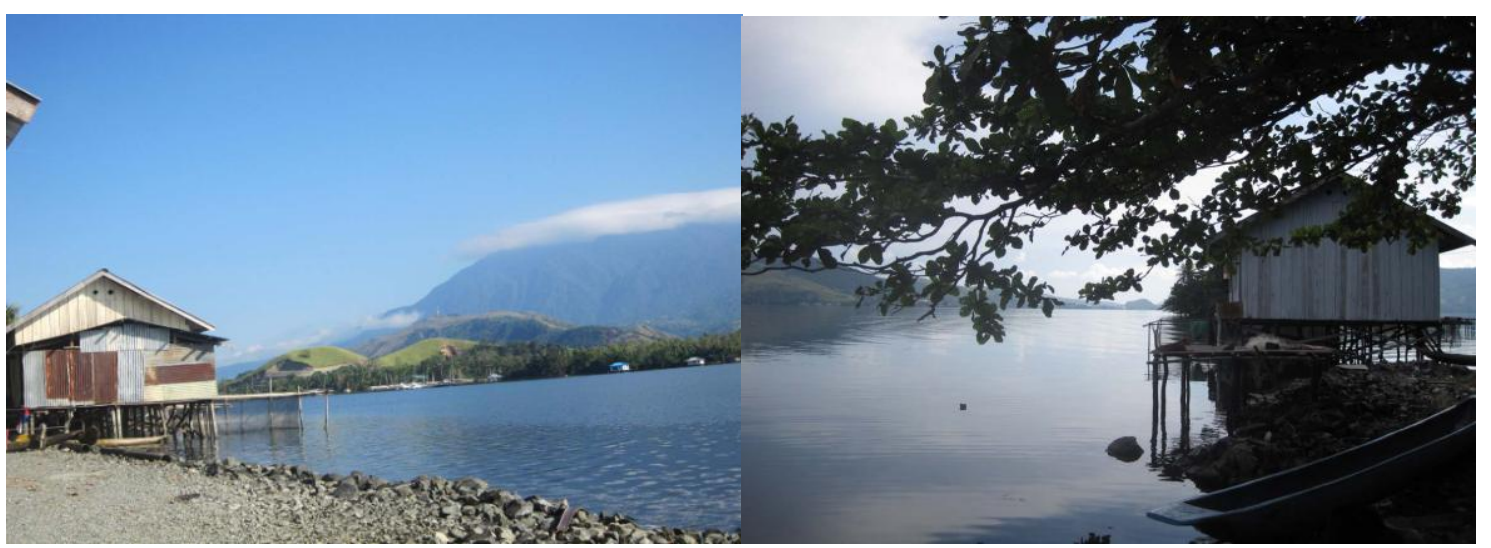

(c) 
Appendix 3.6. Fish sampling sites in Lake Sentani. Zone II/Group 3: Puai (BP); (a) sampling site 1, (b) sampling site 2 , and (c) sampling site 3 .

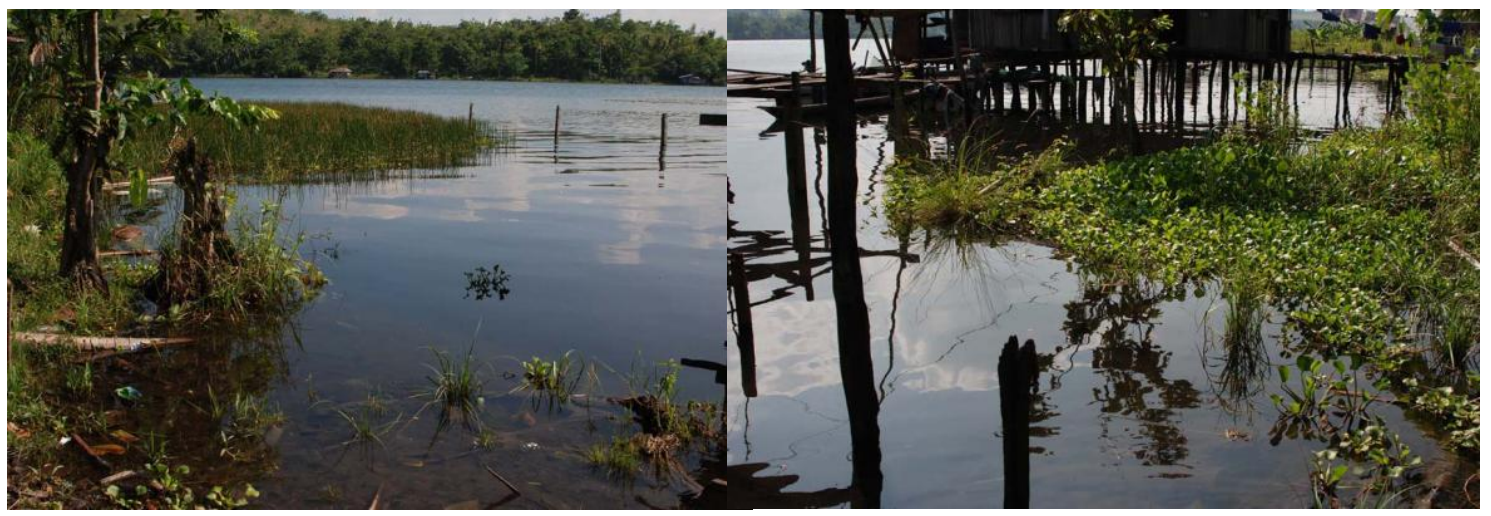

(a)

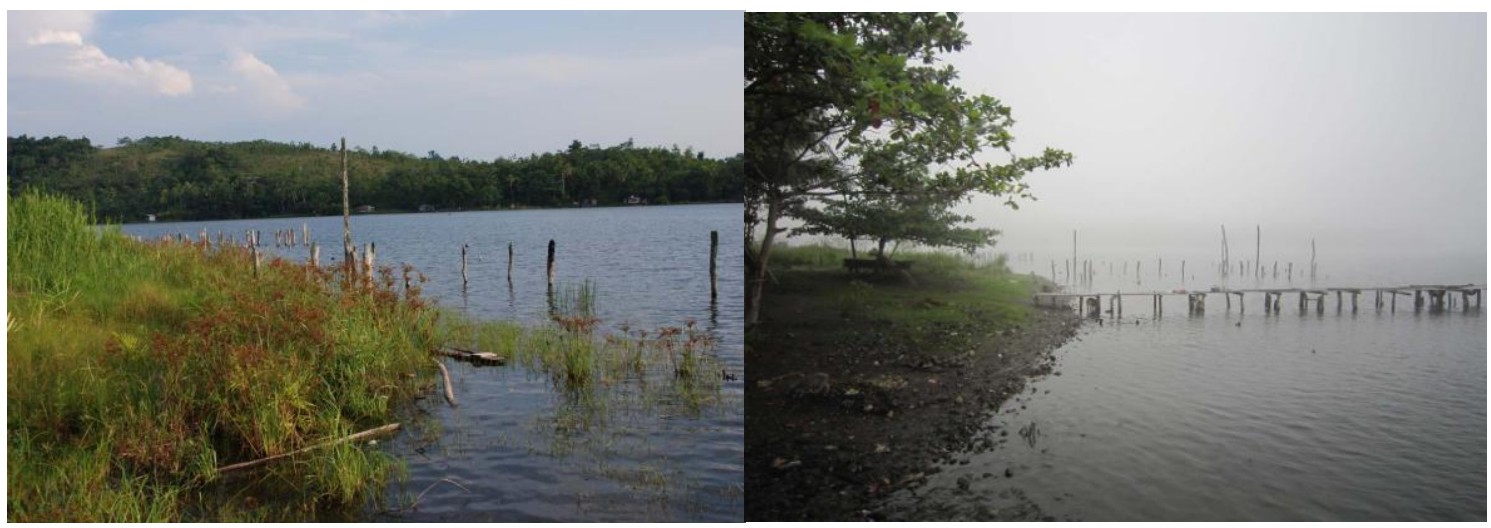

(b)

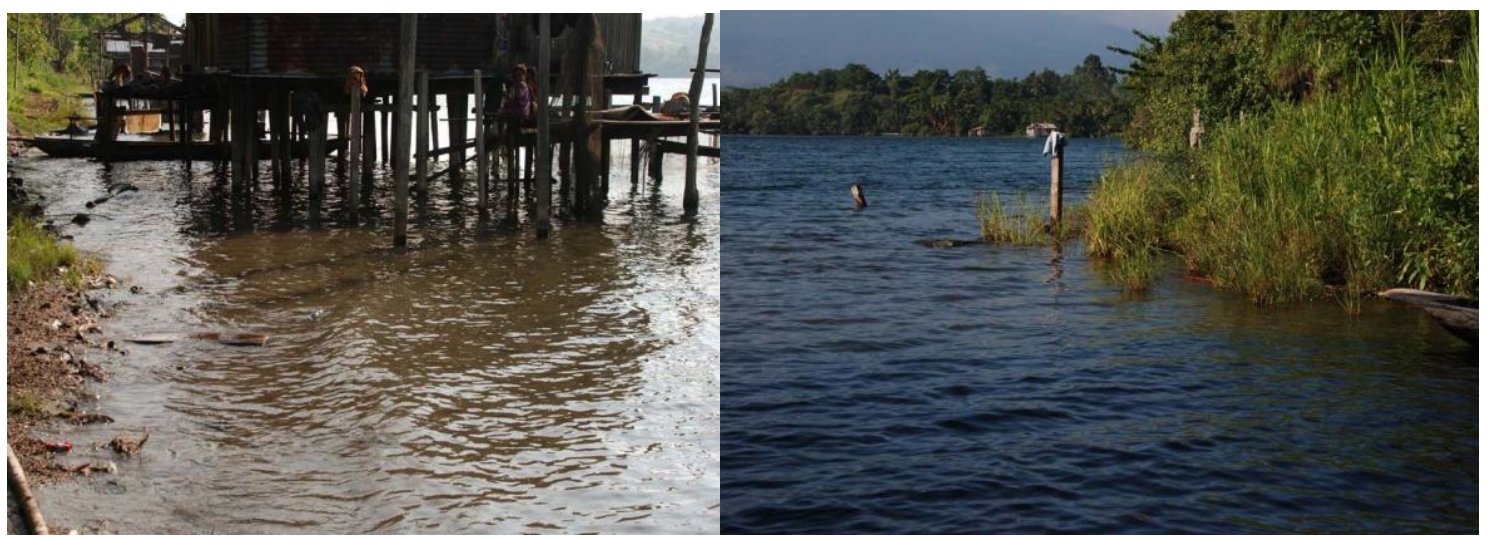

(c) 
Appendix 3.7. Fish sampling sites in Lake Sentani. Zone III/Group 2: Yakonde (CY); (a) sampling site 1 , (b) sampling site 2 , and (c) sampling site 3 .

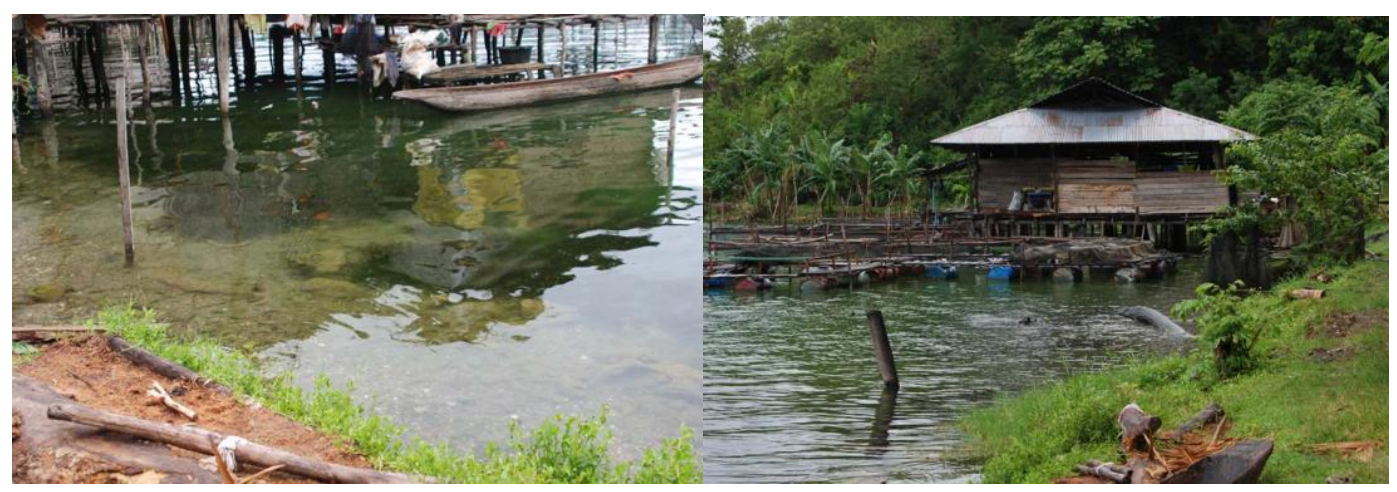

(a)

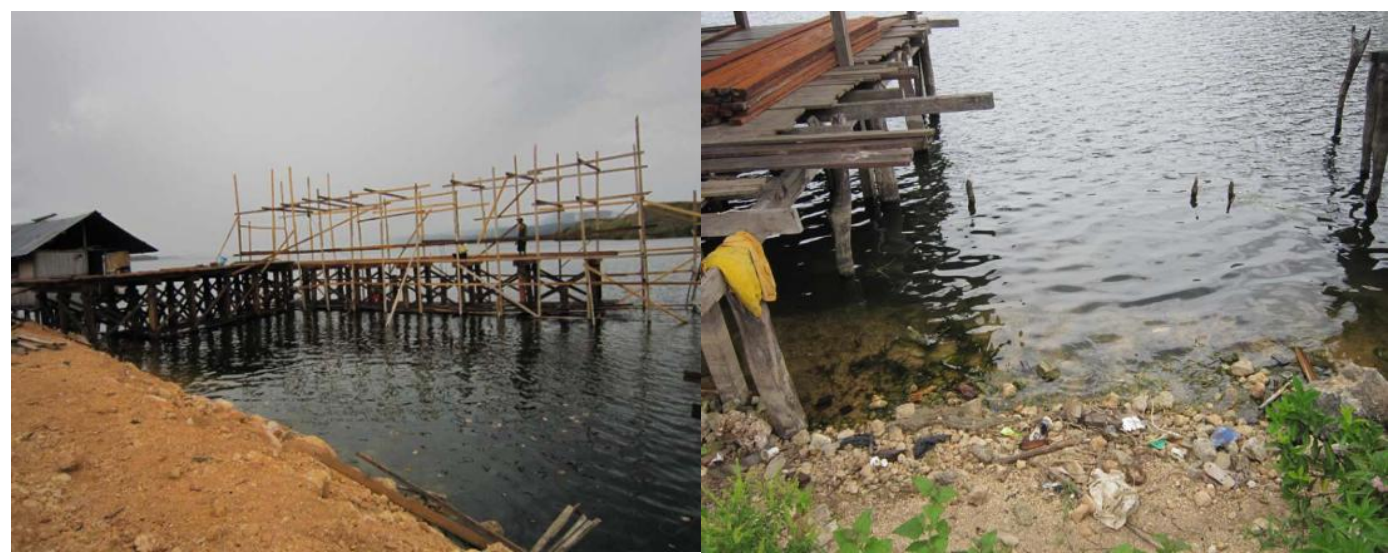

(b)

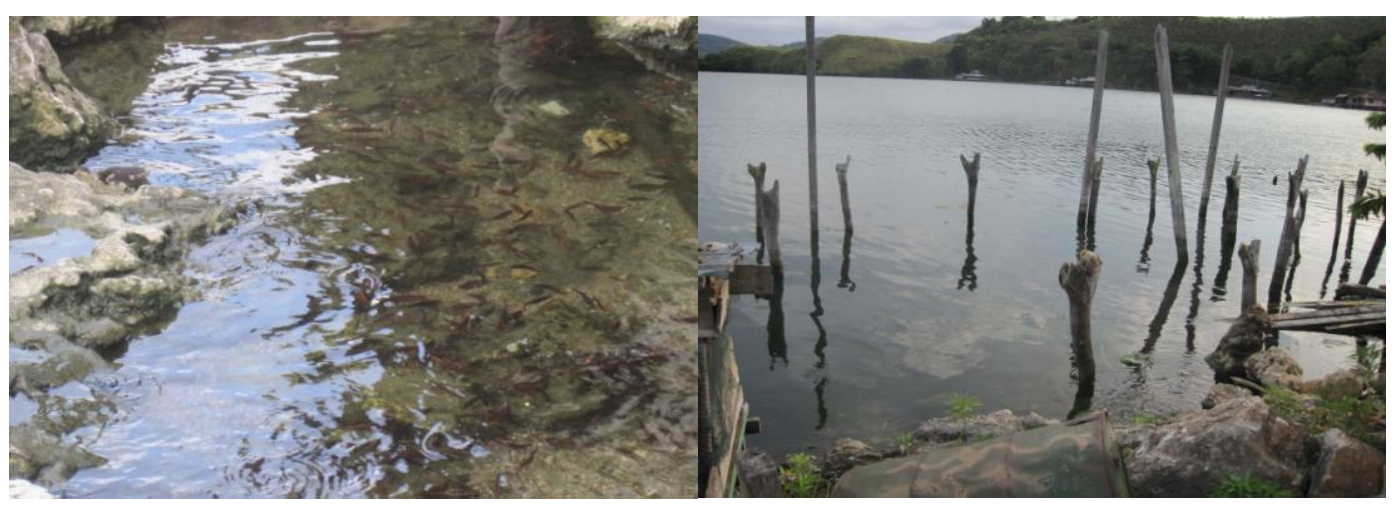

(c) 
Appendix 3.8. Fish sampling sites in Lake Sentani. Zone III/Group 3: Rimi (CR); (a) sampling site 1, (b) sampling site 2 , and (c) sampling site 3 .

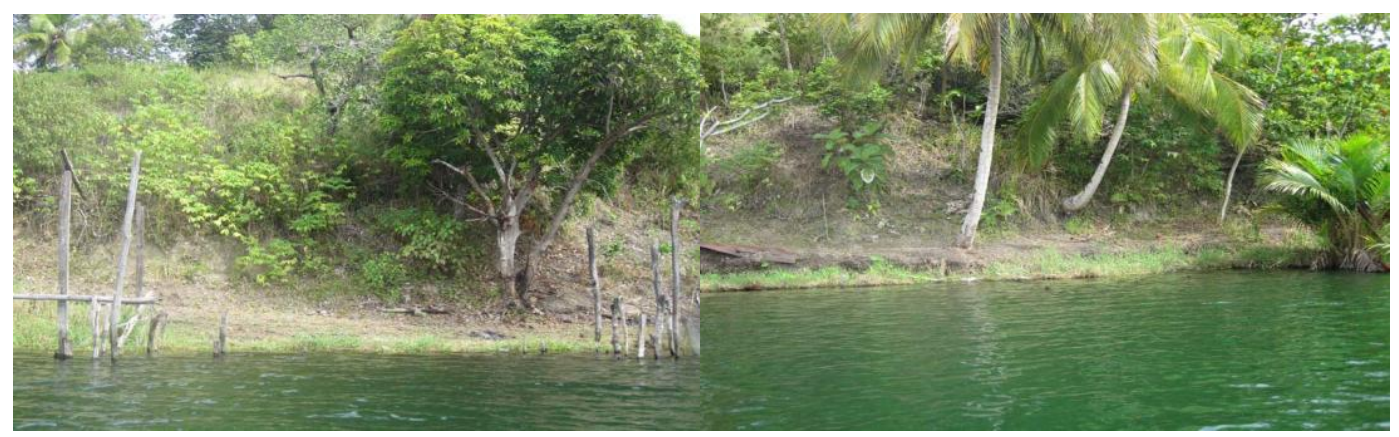

(a)

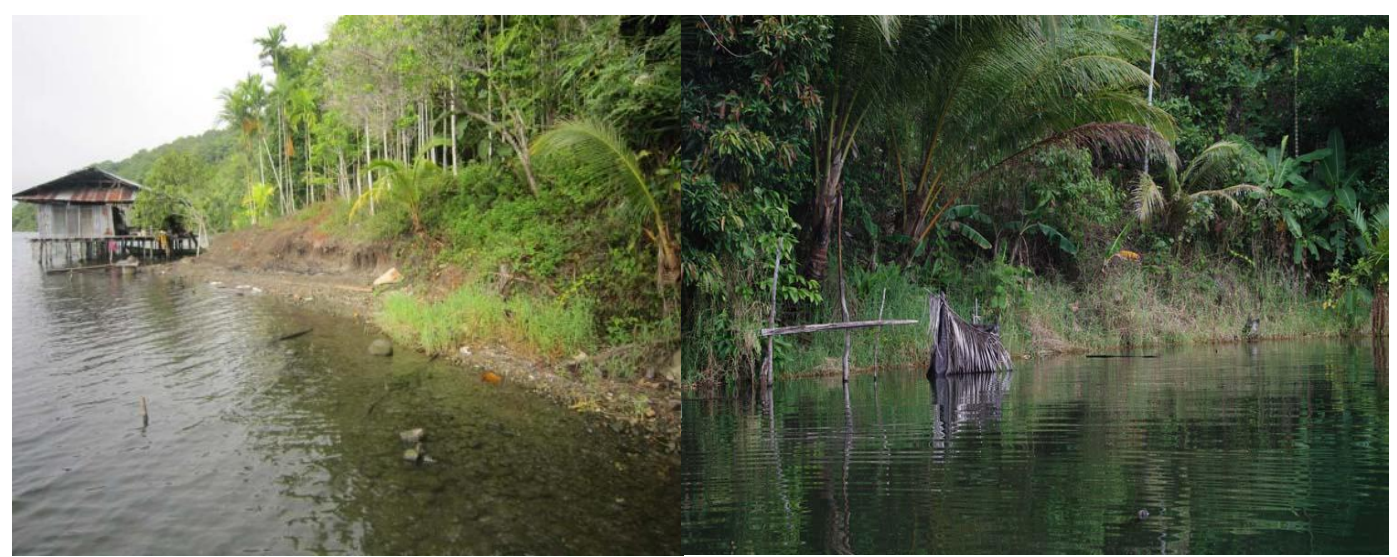

(b)

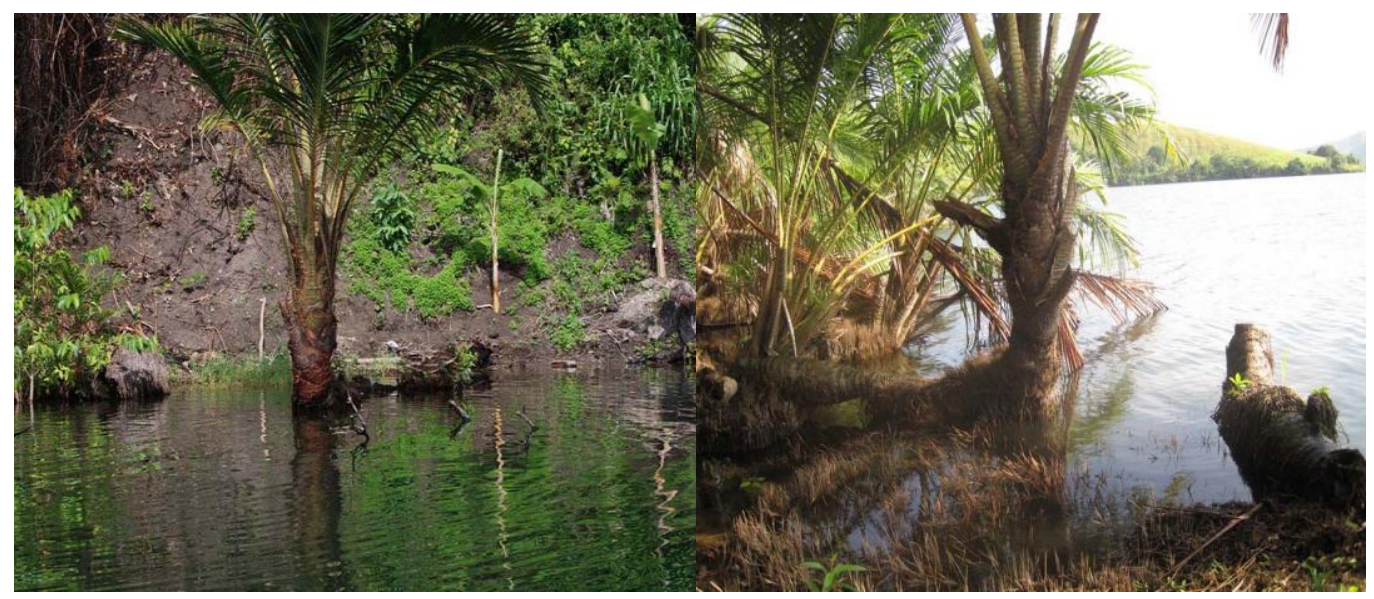

(c) 
Appendix 3.9. Fish sampling sites in Lake Sentani. Zone III/Group 3: Kanale (CK); (a) sampling site 1 , (b) sampling site 2 , and (c) sampling site 3 .

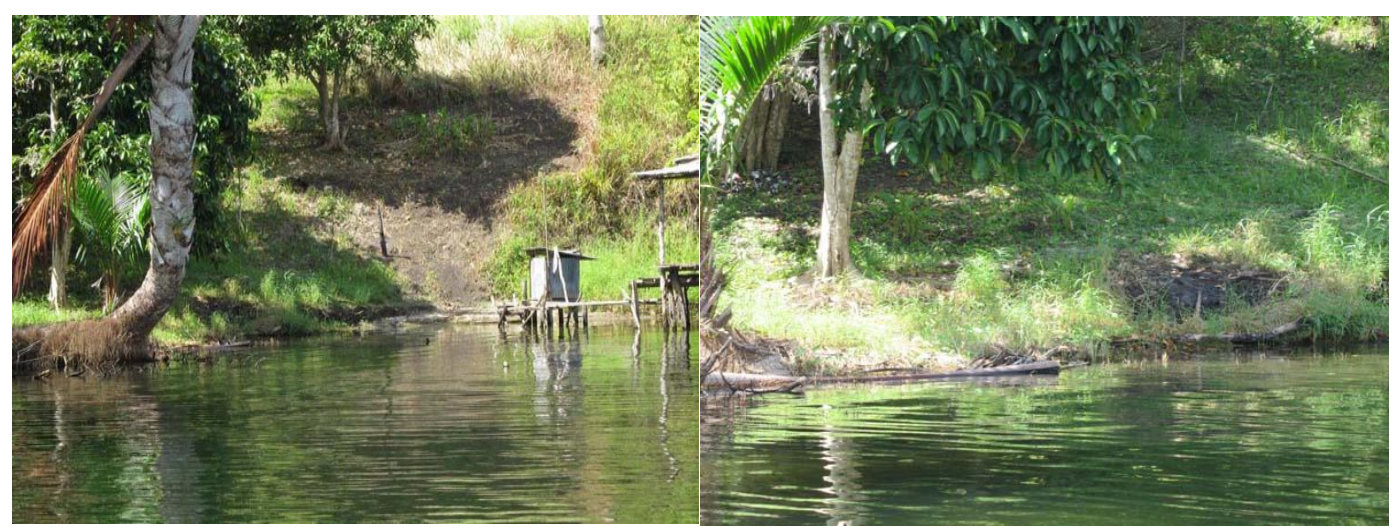

(a)

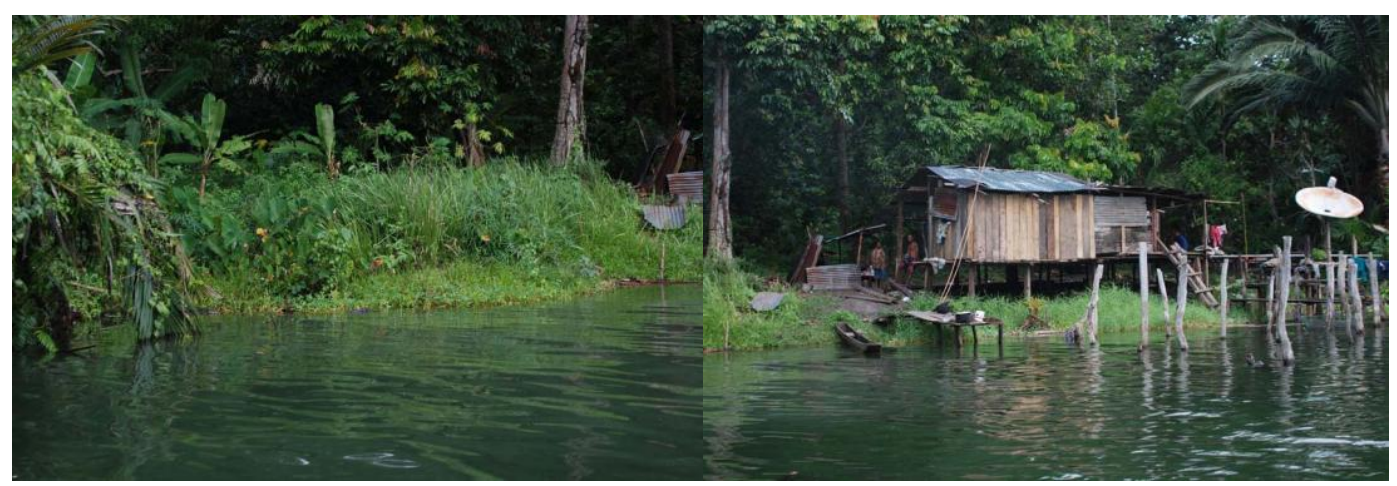

(b)

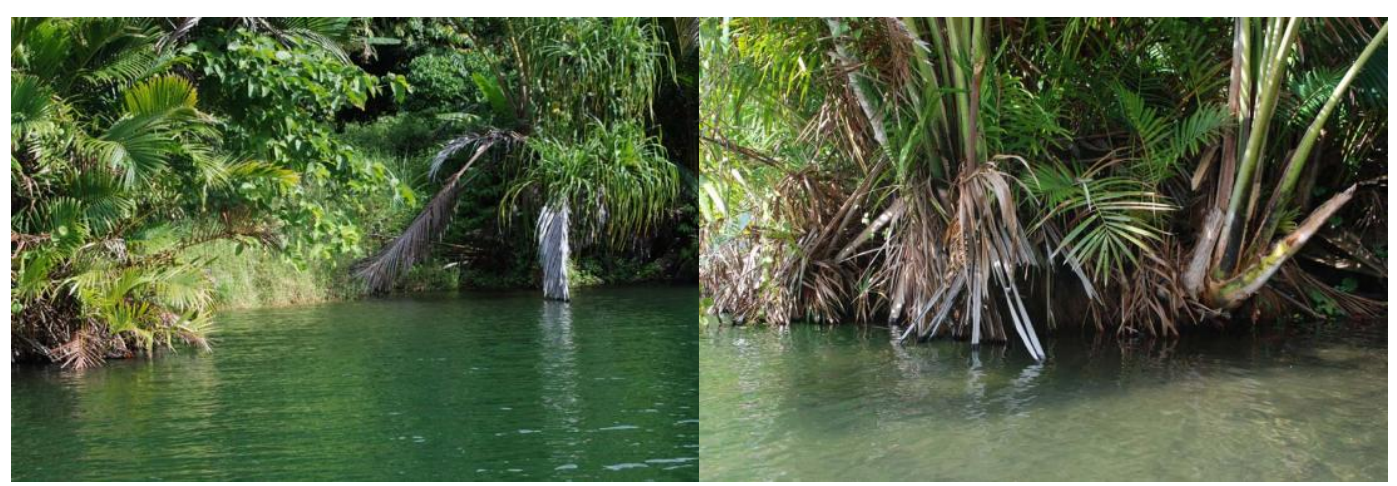

(c) 
Appendix 4. Regrouping of research locations based on water physicochemical parameters. Group 1 comprises AW and AY (red circles), Group 2 comprises AJ and CY (yellow circles), and Group 3 comprises BAy, BAs, BP, CR, and CK (blue circles).

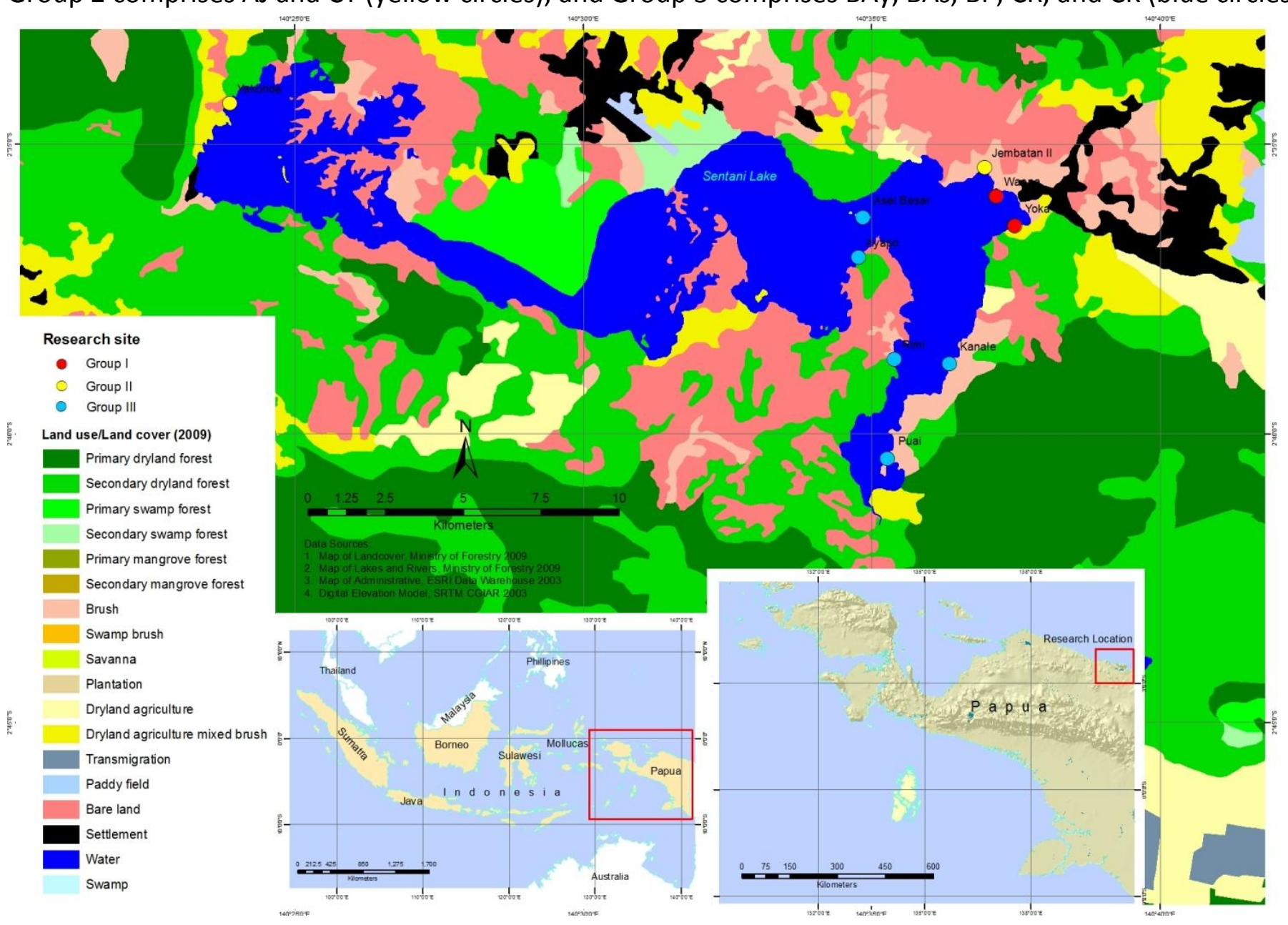


Appendix 5. The ecology of the Red Rainbowfish, including substrate types, turbidity levels, water physicochemical parameter levels, and water and terrestrial vegetation.

\begin{tabular}{|c|c|c|c|c|c|c|c|c|c|c|c|c|c|c|}
\hline \multirow{2}{*}{$\begin{array}{l}\text { Zone/ } \\
\text { Group }\end{array}$} & \multirow[b]{2}{*}{ Location } & \multirow{2}{*}{$\begin{array}{r}\text { Sampling } \\
\text { site }\end{array}$} & \multirow{2}{*}{$\begin{array}{l}\text { Substrate } \\
\text { type }\end{array}$} & \multirow[b]{2}{*}{ Turbidity } & \multicolumn{8}{|c|}{ Physicochemical parameters } & \multirow{2}{*}{$\begin{array}{l}\text { Water } \\
\text { vegetation }\end{array}$} & \multirow{2}{*}{$\begin{array}{l}\text { Terrestrial } \\
\text { vegetation }\end{array}$} \\
\hline & & & & & Temp & $\mathrm{pH}$ & DO & BOD & COD & Nitrate & Nitrite & Phosphate & & \\
\hline \multirow[t]{3}{*}{$1 / 1$} & Waena & 1 & $\begin{array}{l}\text { Mostly silt } \\
\text { and sand; } \\
\text { gravel in } \\
\text { some spots }\end{array}$ & $\begin{array}{l}<14 \text { NTU } \\
(\text { creek); }< \\
5 \text { NTU } \\
\text { (lake) }\end{array}$ & 30.22 & 7.25 & 4.98 & 5.11 & 24.29 & 0.71 & 0.0133 & 0.41 & $\begin{array}{l}\text { Hydrilla } \\
\text { verticillata }\end{array}$ & Predominantly grass \\
\hline & & II & $\begin{array}{l}\text { Sand; } \\
\text { gravel; } \\
\text { rubble }\end{array}$ & $<5$ NTU & & & & & & & & & $\begin{array}{l}\text { Hydrilla } \\
\text { verticillata }\end{array}$ & $\begin{array}{l}\text { Ficus sp.; Artocarpus } \\
\text { heterophyllus; } \\
\text { Pometia pinnata; } \\
\text { Areca catechu; grass }\end{array}$ \\
\hline & & III & $\begin{array}{l}\text { Sand; } \\
\text { gravel; } \\
\text { rubble }\end{array}$ & $<5 \mathrm{NTU}$ & & & & & & & & & $\begin{array}{l}\text { Hydrilla } \\
\text { verticillata; } \\
\text { Eichhornia } \\
\text { crassipes }\end{array}$ & Predominantly grass \\
\hline \multirow[t]{3}{*}{$1 / 1$} & Yoka & I & $\begin{array}{l}\text { Gravel; } \\
\text { rubble }\end{array}$ & $<5$ NTU & & & & & & & & & $\begin{array}{l}\text { Hydrilla } \\
\text { verticillata }\end{array}$ & $\begin{array}{l}\text { Artocarpus } \\
\text { heterophyllus; } \\
\text { Eugenia sp. }\end{array}$ \\
\hline & & II & Gravel & $<5$ NTU & & & & & & & & & $\begin{array}{l}\text { Hydrilla } \\
\text { verticillata }\end{array}$ & Predominantly grass \\
\hline & & III & Silt; sand & $<5$ NTU & & & & & & & & & $\begin{array}{l}\text { Hydrilla } \\
\text { verticillata; } \\
\text { Vallisneria } \\
\text { americana }\end{array}$ & \\
\hline $1 / 2$ & $\begin{array}{l}\text { Jembatan } \\
\text { II }\end{array}$ & I & $\begin{array}{l}\text { Silt; sand; } \\
\text { gravel }\end{array}$ & $\begin{array}{l}<240 \text { NTU } \\
\text { (creek); } \\
<5 \text { NTU } \\
\text { (lake) }\end{array}$ & 31.06 & 7.14 & 4.99 & 8.23 & 83.60 & 0.0035 & 0.0012 & 0.875 & $\begin{array}{l}\text { Hydrilla } \\
\text { verticillata }\end{array}$ & $\begin{array}{l}\text { Metroxylon sagu; } \\
\text { grasses }\end{array}$ \\
\hline
\end{tabular}


Appendix 5. The ecology of the Red Rainbowfish, including substrate types, turbidity levels, water physicochemical parameter levels, and water and terrestrial vegetation (continued).

\begin{tabular}{|c|c|c|c|c|c|c|c|c|c|c|c|c|c|c|}
\hline \multirow{2}{*}{$\begin{array}{l}\text { Zone/ } \\
\text { Group }\end{array}$} & \multirow[b]{2}{*}{ Location } & \multirow{2}{*}{$\begin{array}{r}\text { Sampling } \\
\text { site }\end{array}$} & \multirow[b]{2}{*}{ Substrate type } & \multirow[b]{2}{*}{ Turbidity } & \multicolumn{8}{|c|}{ Physicochemical parameters } & \multirow{2}{*}{$\begin{array}{l}\text { Water } \\
\text { vegetation }\end{array}$} & \multirow{2}{*}{$\begin{array}{l}\text { Terrestrial } \\
\text { vegetation }\end{array}$} \\
\hline & & & & & Temp & $\mathrm{pH}$ & $\mathrm{DO}$ & $\mathrm{BOD}$ & COD & Nitrate & Nitrite & Phosphate & & \\
\hline \multirow[t]{2}{*}{$1 / 2$} & $\begin{array}{l}\text { Jembatan } \\
\text { II }\end{array}$ & II & Gravel; rubble & $<5$ NTU & & & & & & & & & $\begin{array}{l}\text { Hydrilla } \\
\text { verticillata }\end{array}$ & \\
\hline & & III & Silt; sand & $<5$ NTU & & & & & & & & & $\begin{array}{l}\text { Hydrilla } \\
\text { verticillata; } \\
\text { water lily }\end{array}$ & $\begin{array}{l}\text { Artocarpus } \\
\text { heterophyllus; } \\
\text { Eugenia sp.; Musa } \\
\text { sp. }\end{array}$ \\
\hline \multirow[t]{3}{*}{$111 / 2$} & Yakonde & 1 & Gravel; rubble & $<5$ NTU & & & & & & & & & $\begin{array}{l}\text { Hydrilla } \\
\text { verticillata }\end{array}$ & Grass \\
\hline & & II & Sand; gravel & $<5 \mathrm{NTU}$ & & & & & & & & & $\begin{array}{l}\text { Hydrilla } \\
\text { verticillata }\end{array}$ & \\
\hline & & III & $\begin{array}{l}\text { Gravel; } \\
\text { rubble; } \\
\text { boulder }\end{array}$ & $<5$ NTU & & & & & & & & & $\begin{array}{l}\text { Hydrilla } \\
\text { verticillata }\end{array}$ & \\
\hline \multirow[t]{3}{*}{$11 / 3$} & Ayapo & I & Gravel; rubble & $<5$ NTU & 30.33 & 7.06 & 4.80 & 3.11 & 23.29 & 0.18 & 0.0024 & 0.295 & & Pometia pinnata \\
\hline & & II & Gravel; rubble & $<5 \mathrm{NTU}$ & & & & & & & & & & Ficus sp. \\
\hline & & III & Gravel; rubble & $<5 \mathrm{NTU}$ & & & & & & & & & & $\begin{array}{l}\text { Anacardium sp.; } \\
\text { Delonix regia }\end{array}$ \\
\hline \multirow[t]{3}{*}{$11 / 3$} & Asei & 1 & Gravel; rubble & $<5 \mathrm{NTU}$ & & & & & & & & & $\begin{array}{l}\text { Eichhornia } \\
\text { crassipes }\end{array}$ & $\begin{array}{l}\text { Cocos nucifera; } \\
\text { herbs }\end{array}$ \\
\hline & & ॥ & Gravel; rubble & $<5$ NTU & & & & & & & & & & Inocarpus fagifer \\
\hline & & III & Gravel; rubble & $<5$ NTU & & & & & & & & & & Terminalia catappa \\
\hline
\end{tabular}


Appendix 5. The ecology of the Red Rainbowfish, including substrate types, turbidity levels, water physicochemical parameter levels, and water and terrestrial vegetation (continued).

\begin{tabular}{|c|c|c|c|c|c|c|c|c|c|c|c|c|c|c|}
\hline \multirow{2}{*}{$\begin{array}{l}\text { Zone/G } \\
\text { roup }\end{array}$} & \multirow{2}{*}{ Location } & \multirow{2}{*}{$\begin{array}{r}\text { Sampling } \\
\text { site }\end{array}$} & \multirow{2}{*}{$\begin{array}{l}\text { Substrate } \\
\text { type }\end{array}$} & \multirow[b]{2}{*}{ Turbidity } & \multicolumn{8}{|c|}{ Physicochemical parameters } & \multirow{2}{*}{$\begin{array}{l}\text { Water } \\
\text { vegetation }\end{array}$} & \multirow{2}{*}{$\begin{array}{l}\text { Terrestrial } \\
\text { vegetation }\end{array}$} \\
\hline & & & & & Temp & $\mathrm{pH}$ & $\mathrm{DO}$ & $\mathrm{BOD}$ & COD & Nitrate & Nitrite & Phosphate & & \\
\hline \multirow[t]{3}{*}{$\mathrm{II} / 3$} & Puai & 1 & Mud & $<5$ NTU & & & & & & & & & $\begin{array}{l}\text { Eichhornia } \\
\text { crassipes; } \\
\text { Grass }\end{array}$ & $\begin{array}{l}\text { Eugenia sp.; Pometia } \\
\text { pinnata }\end{array}$ \\
\hline & & II & Sand & $<5$ NTU & & & & & & & & & & Predominantly grass \\
\hline & & III & Sand; gravel & $<5$ NTU & & & & & & & & & & Predominantly grass \\
\hline \multirow[t]{3}{*}{$\mathrm{III} / 3$} & Rimi & I & Silt; sand & $<5$ NTU & 30.33 & 7.06 & 4.80 & 3.11 & 23.29 & 0.18 & 0.0024 & 0.295 & & $\begin{array}{l}\text { Herbs including } \\
\text { Ludwigia octovaluis; } \\
\text { Desmodium sp.; } \\
\text { Kylinga } \\
\text { monocephala; } \\
\text { Commelina } \\
\text { nudiflora; Brachiaria } \\
\text { sp.; and Vigna sp. }\end{array}$ \\
\hline & & ॥ & Silt; sand & $<5$ NTU & & & & & & & & & & $\begin{array}{l}\text { Trees including } \\
\text { Pterocarpus indicus; } \\
\text { Hibiscus sp.; Ficus sp }\end{array}$ \\
\hline & & III & Sand; gravel & $<5$ NTU & & & & & & & & & & $\begin{array}{l}\text { Trees such as } \\
\text { Metroxylon sagu, } \\
\text { Pterocarpus indicus, } \\
\text { Commersonia } \\
\text { bartramia, Bambusa } \\
\text { sp.; Cyperus sp.; } \\
\text { Imperata cylindrica }\end{array}$ \\
\hline
\end{tabular}


Appendix 5. The ecology of Red Rainbowfish, including substrate types, turbidity levels, water physicochemical parameters levels, water and terrestrial vegetation (continued).

\begin{tabular}{|c|c|c|c|c|c|c|c|c|c|c|c|c|c|c|}
\hline \multirow{2}{*}{$\begin{array}{l}\text { Zone/ } \\
\text { Group }\end{array}$} & \multirow[b]{2}{*}{ Location } & \multirow{2}{*}{$\begin{array}{r}\text { Sampling } \\
\text { site }\end{array}$} & \multirow{2}{*}{$\begin{array}{l}\text { Substrate } \\
\text { type }\end{array}$} & \multirow[b]{2}{*}{ Turbidity } & \multicolumn{8}{|c|}{ Physicochemical parameters } & \multirow{2}{*}{$\begin{array}{l}\text { Water } \\
\text { vegetation }\end{array}$} & \multirow{2}{*}{$\begin{array}{l}\text { Terrestrial } \\
\text { vegetation }\end{array}$} \\
\hline & & & & & Temp & $\mathrm{pH}$ & DO & BOD & COD & Nitrate & Nitrite & Phosphate & & \\
\hline \multirow[t]{3}{*}{$\mathrm{III} / 3$} & Kanale & 1 & Sand; gravel & $<5$ NTU & 30.33 & 7.06 & 4.80 & 3.11 & 23.29 & 0.18 & 0.0024 & 0.295 & & $\begin{array}{l}\text { Predominantly grass } \\
\text { and some domestic } \\
\text { trees; Metroxylon } \\
\text { sagu }\end{array}$ \\
\hline & & II & Mud & $<5$ NTU & & & & & & & & & & $\begin{array}{l}\text { Paspalum } \\
\text { conjugatum and } \\
\text { some unidentified } \\
\text { species }\end{array}$ \\
\hline & & III & Gravel & $<5$ NTU & & & & & & & & & & $\begin{array}{l}\text { Herbs including } \\
\text { Alternanthera sp., } \\
\text { Lepistemon } \\
\text { urceolatus, Pueraria } \\
\text { sp., Piper aduncum, } \\
\text { and Cyperus diffuses; } \\
\text { trees such as } \\
\text { Anthocephalus } \\
\text { chinensis }\end{array}$ \\
\hline
\end{tabular}


Appendix 6.1. The fish community in Lake Sentani: endemic species.

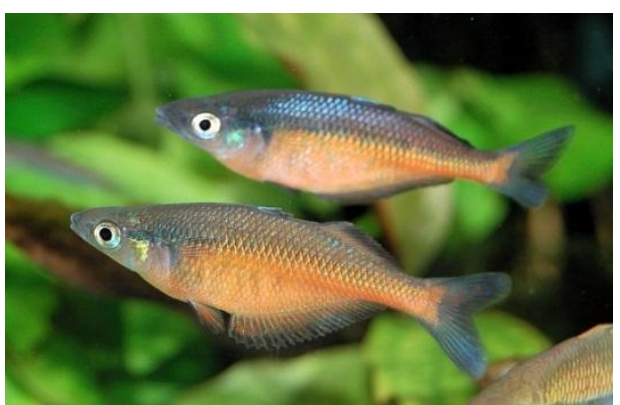

Fig. 6.1.1. Chilatherina sentaniensis (Photo by G.R. Allen)

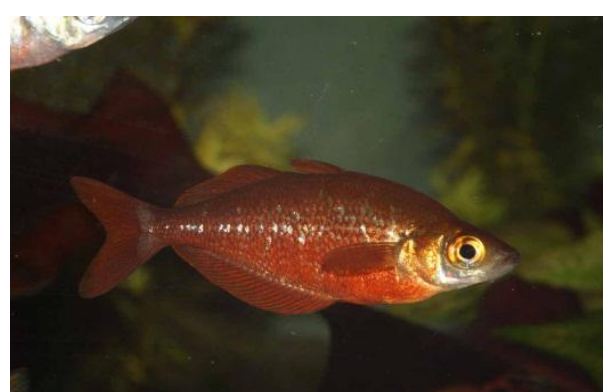

Fig. 6.1.2. Glossolepis incisus (Photo by J. Graf)

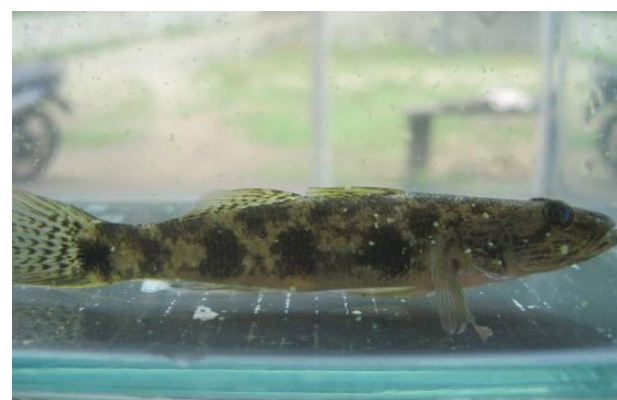

Fig. 6.1.3. Glossogobius sp.

(Photo by H. L. Ohee) 
Appendix 6.2. The fish community in Lake Sentani: indigenous species.

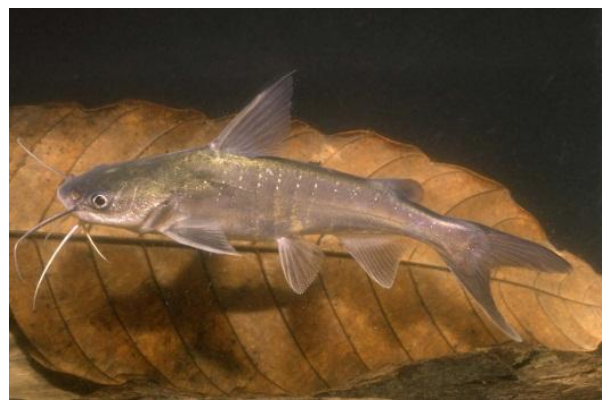

Fig. 6.2.1. Arius velutinus (Photo by G. R. Allen)

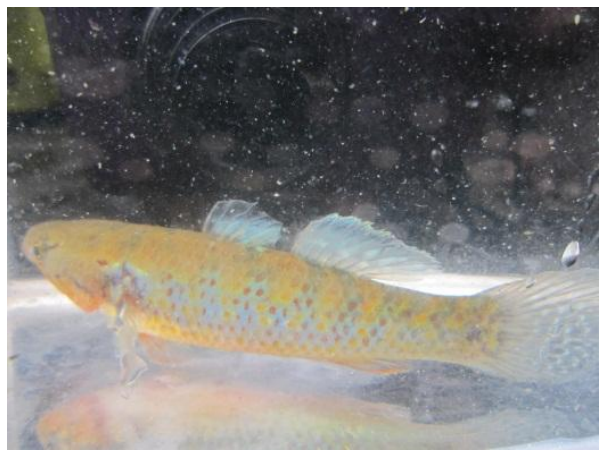

Fig. 6.2.3. Giuris margaritacea (Photo by H. L. Ohee)

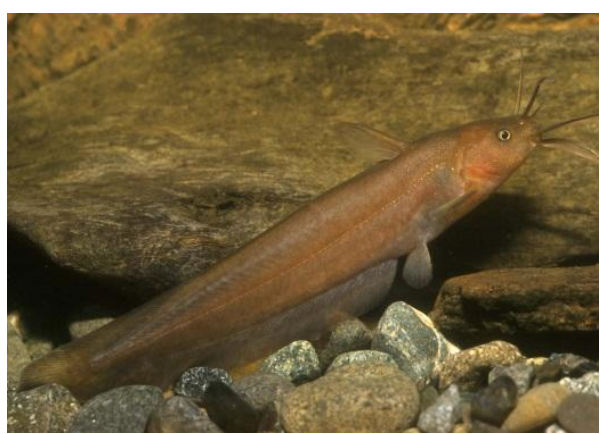

Fig. 6.2.5. Neosilurus novaeguineae (Photo by G. R. Allen)

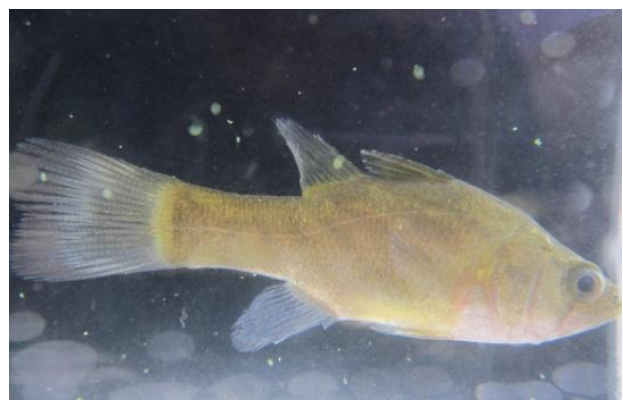

Fig. 6.2.2. Glossamia wichmanni (Photo by H. L. Ohee)

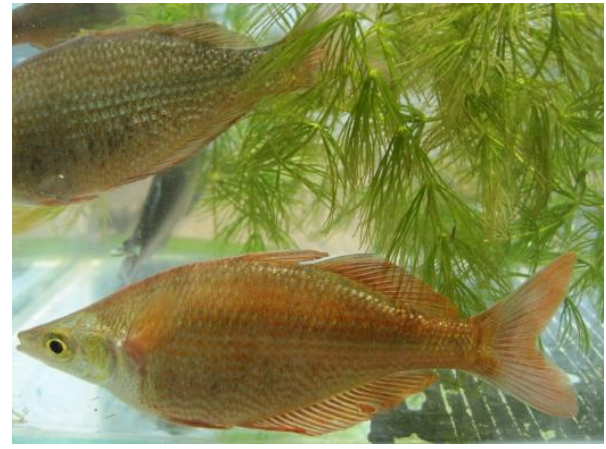

Fig. 6.2.4. Chilatherina fasciata (Photo by H. L. Ohee)

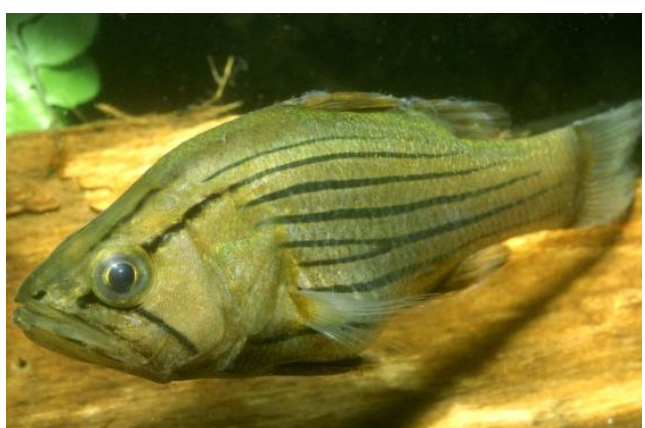

Fig. 6.2.6. Glossamia beauforti

(Photo by G. R. Allen)

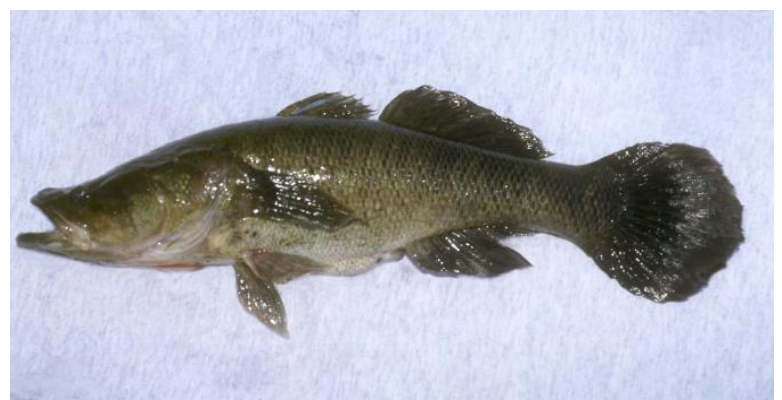

Fig. 6.2.7. Oxyeleotris heterodon

(Photo by G. R. Allen) 
Appendix 6.3. The fish community in Lake Sentani: anadromous species.

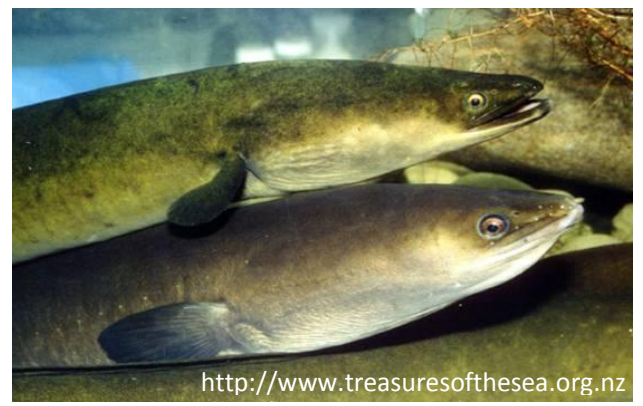

Fig. 6.3.1. Anguilla australis (Photo by S. M. Moore)

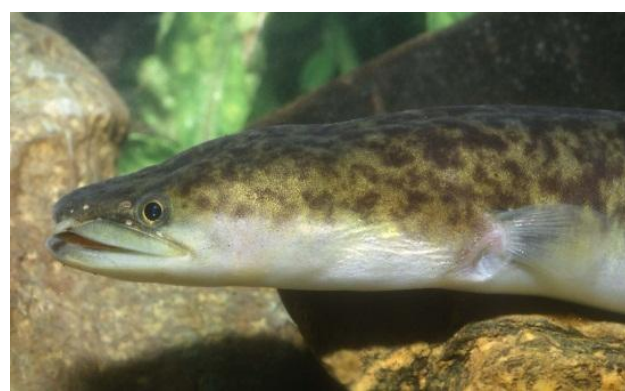

Fig. 6.3.3. Anguilla marmorata (Photo by G. R. Allen)

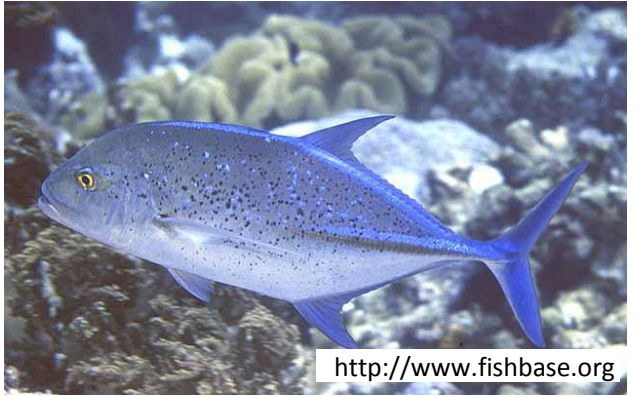

Fig. 6.3.5. Caranx melampygus

(Photo by R. A. Patzner)

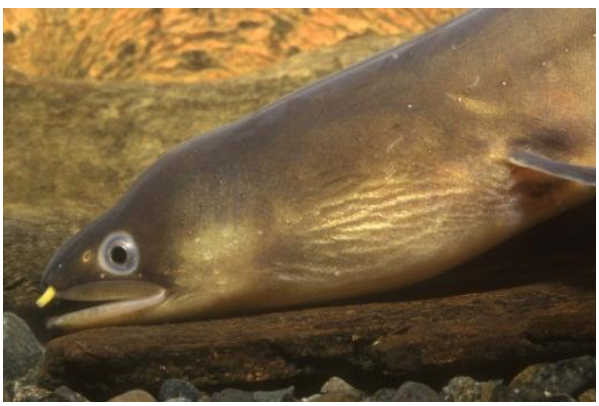

Fig. 6.3.2. Anguilla bicolor (Photo by G. R. Allen)

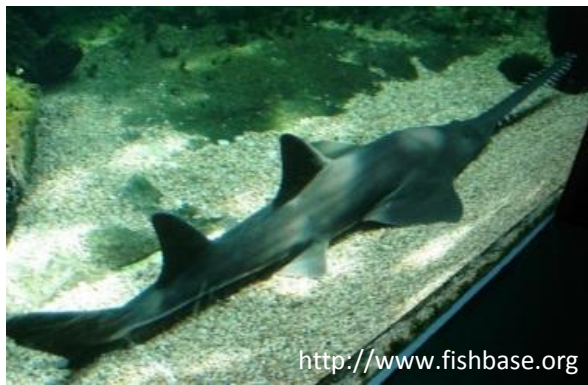

Fig. 6.3.4. Pristis microdon

(Photo by T. Meyer)

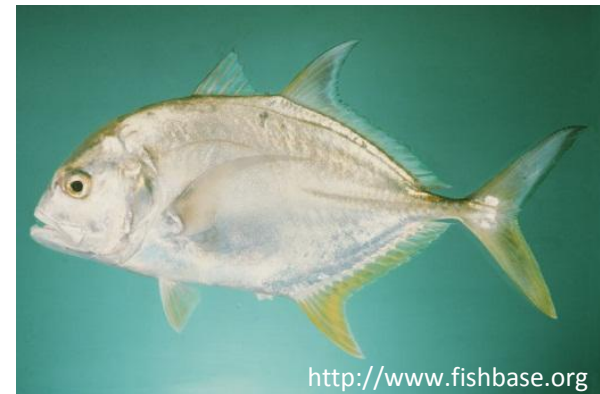

Fig. 6.3.6. Caranx ignobilis

(Photo by J. E. Randall)

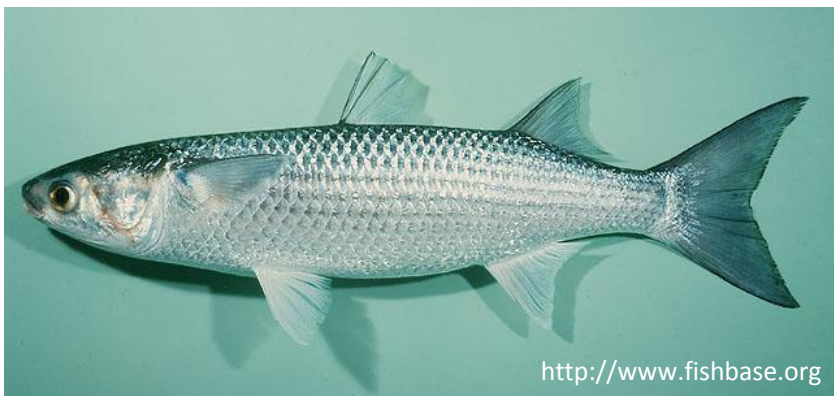

Fig. 6.3.7. Mugil cephalus

(Photo by J. E. Randall) 
Appendix 6.4. The fish community in Lake Sentani: introduced species.

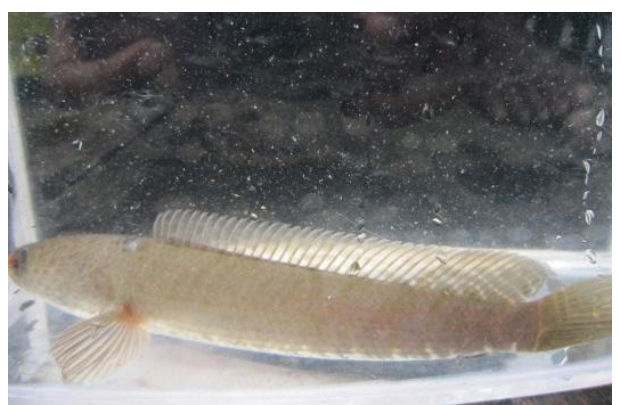

Fig. 6.4.1. Channa striata

(Photo by H. L. Ohee)

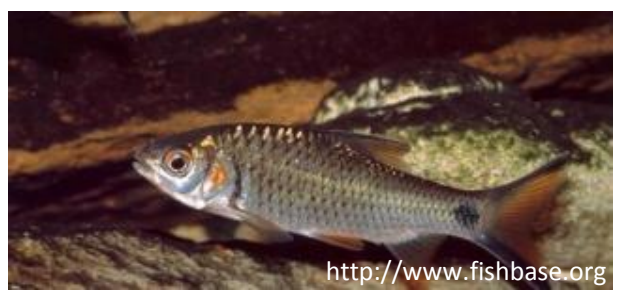

Fig. 6.4.3. Systomus orphoides (Photo by J. C. P. Diaz)

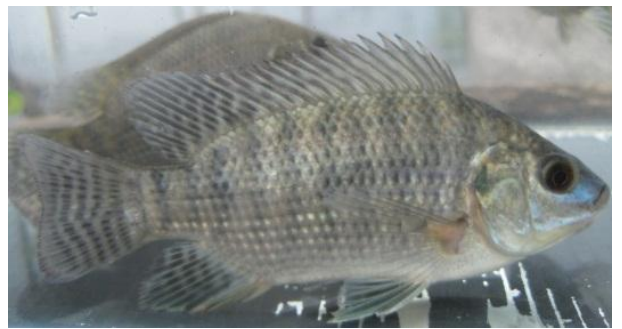

Fig. 6.4.5. Oreochromis niloticus (Photo by H. L. Ohee)

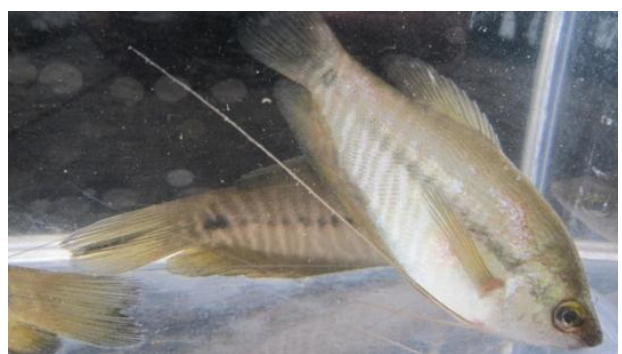

Fig. 6.4.7. Trichogaster pectoralis (Photo by H. L. Ohee)

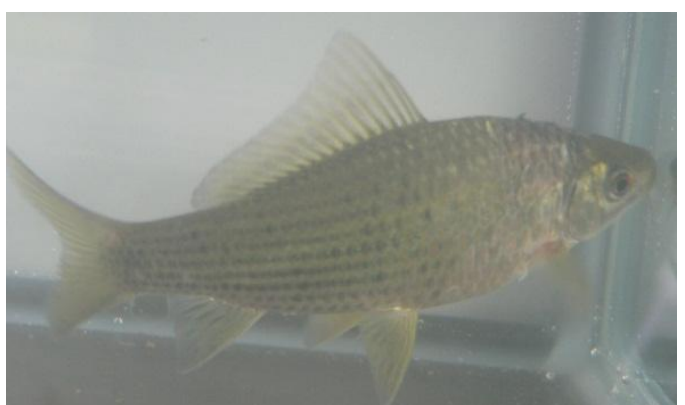

Fig. 6.4.2. Puntius gonionotus

(Photo by H. L. Ohee)

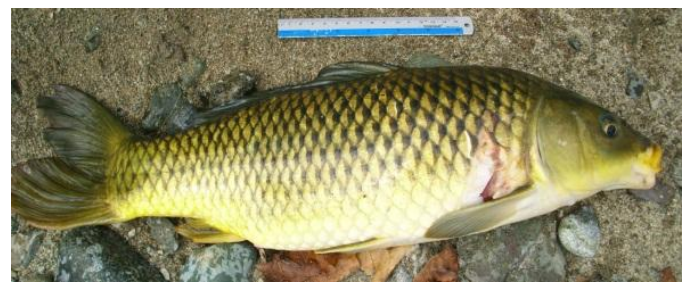

Fig. 6.4.4. Cyprinus carpio

(Photo by H. L. Ohee)

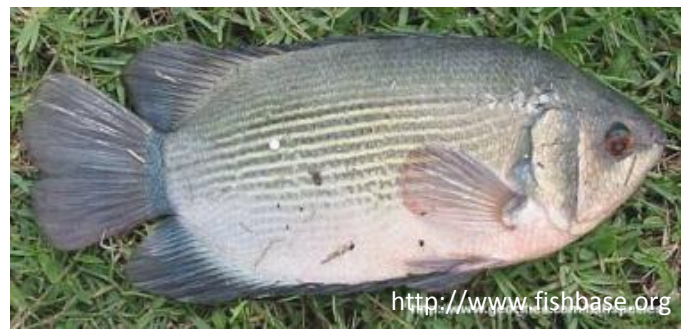

Fig. 6.4.6. Helostoma temminckii

(Photo by E. Chuan)

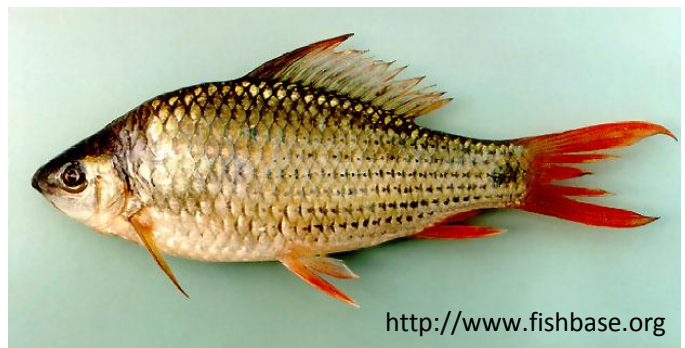

Fig. 6.4.8. Osteochilus hasseltii

(Photo by T. Warren) 
Appendix 6.4. The fish community in Lake Sentani: introduced species (continued).

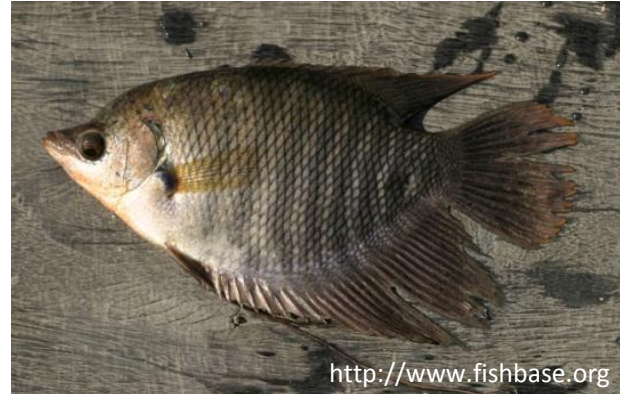

Fig. 6.4.9. Osphronemus goramy (Photo by D. Bjerregaard)

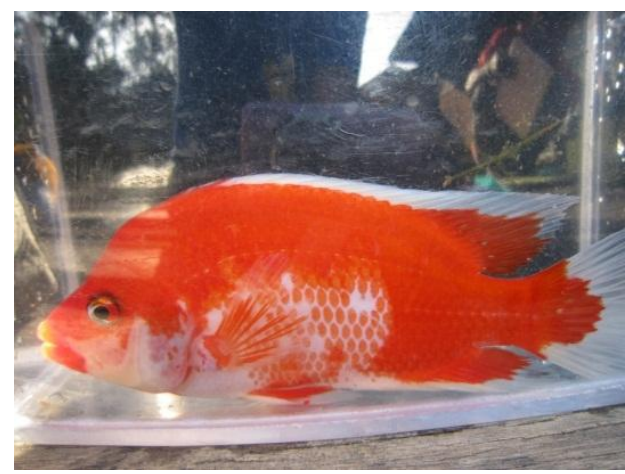

Fig. 6.4.11. Amphilophus citrinellus (Photo by H. L. Ohee)

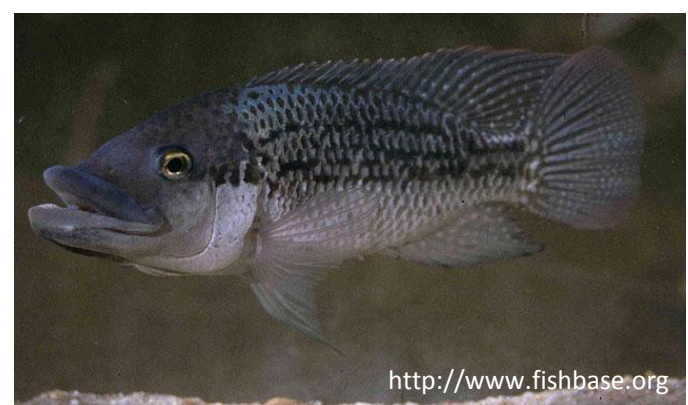

Fig. 6.4.10. Oreochromis mossambicus (Photo by B. Gratwicke)

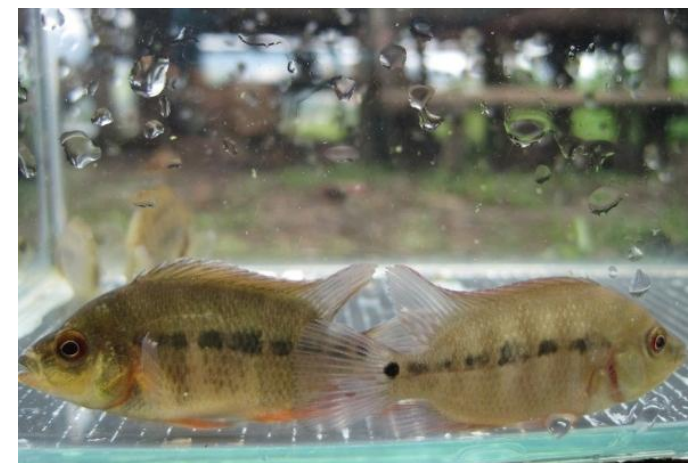

Fig. 6.4.12. Amphilophus longimanus (Photo by H. L. Ohee)

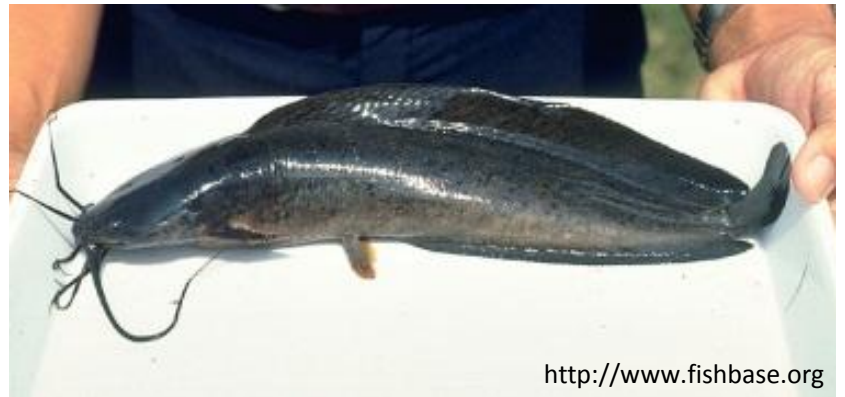

Fig. 6.4.13. Clarias batrachus (Photo by L. L. Lovshin) 


\section{Curriculum Vitae}

\section{Personal Data}

Name

Place, date of birth

Address

Nationality

\section{Education}

$2002-2005$

$1991-1996$

Work Experience

$1997-2008$

2001 - present
Henderite Loisa Ohee

Papua-Indonesia, 24 July 1971

Gg. Jati I No. 04 Perumnas II Waena, Jayapura, 99358, Papua, Indonesia.

E-mail: hohee08@gmail.com

Indonesian

Master Program in Biodiversity

Conservation, Faculty of Biology, University of Indonesia, Depok-West Java, Indonesia.

Bachelor Program in Biology, Faculty of Teaching and Educational Science, Cenderawasih University, Papua, Indonesia.

Junior Ecologists at Conservation

International $(\mathrm{Cl})$, Papua Field Office in

Jayapura, Papua, Indonesia.

Lecturer at Department of Biology,

Faculty of Mathematics and Natural Sciences,

Cenderawasih University, Papua,

Indonesia. 